\title{
PASANDO DE LA VIDA RURAL A LA URBANA EN GUADALUPE: ANÉCDOTAS EN UNA PULPERÍA DE BARRIO
}

\author{
Passing from rural to urban life in Guadalupe: \\ anecdotes in a pulpería of neighborhood
}

\author{
William Elizondo Calderón \\ Universidad de Costa Rica, Costa Rica \\ wileca@yahoo.com.mx
}

Recibido: 1-10-2016

Aprobado: 18-11-2016

\section{RESUMEN}

William Elizondo Calderón es licenciado en Historia y máster en Administración de Empresas, se desempeña como docente en la Sección de Historia de la Cultura de la Escuela de Estudios Generales de la Universidad de Costa Rica.

\begin{abstract}
La transformación de los espacios rurales en urbanos se ve acompañada de cambios en la vida cotidiana producto de la dinámica de desarrollo local. Esto se manifiesta en el espacio de barrio y más allá en el de la ciudad, tal y como se visualiza para Guadalupe, Goicoechea, San José; a través de las anécdotas narradas en el contexto de la pulpería. El trato con vecinos en un espacio de diálogo permitió acceder a una dinámica social propia, en la cual la remembranza y la añoranza, dan cuenta de una transmutación continua de vivencias, tradiciones y costumbres, opacadas por el consumismo, la tecnología, las redes sociales, y por consiguiente, otro estilo de vida.
\end{abstract}

Palabras clave: rural; urbano; anécdotas; pulpería; Guadalupe, barrio

\begin{abstract}
The transformation of rural spaces into urban spaces is accompanied by changes in daily life as a result of the dynamics of local development. This manifests itself in the space of the neighborhood and beyond, in the city, as it is visualized for Guadalupe, Goicoechea, San José; through the anecdotes narrated in the context of the pulpería. The conversation with neighbors in a space of dialogue allowed access to a social dynamic of their own, in which remembrance and longing, give account of a continuous transmutation of experiences, traditions and customs, overshadowed by consumerism, technology, social networks, and therefore, another lifestyle.
\end{abstract}

Keywords: rural; urban; anecdotes; pulpería; Guadalupe, neighborhood 


\section{A MANERA DE INTRODUCCIÓN}

En estas narraciones las imágenes, voces y personajes van surgiendo conforme la memoria y algo de imaginación, completan las anécdotas sobre un barrio donde las vivencias transmutan definitivamente lo rural en urbano. La anterior vida del campo se transforma, por la fuerza de la dinámica del trabajo, la convivencia social y la connivencia de lo tradicional con lo mercantil, en una integración urbana sin retorno.

No solo una o varias familias viven la conversión de su trajín de vida, sino que el mismo barrio y más allá, la ciudad de Guadalupe, están consolidando su paso de la tranquilidad y parsimonia rurales, a la movilidad y algarabía urbanas.

Las familias no solo se transforman a la vida urbana como consecuencia de la dinámica del desarrollo local, también se transforman por que muchas de ellas, provienen del medio rural, habiendo migrado o regresado a la ciudad, para ingresar al proceso de adaptación a la vida urbana, sea como obreros, artesanos 0 micro productores independientes. Para los niños y adolescentes, es su paso de la escasa vida social en fincas aisladas y montañosas donde la dinámica se reduce a la familia y algunos vecinos cercanos, a la intensa de vecinos contiguos y cotidianos, además de compañeros y acompañantes de actividades escolares.

El propio desarrollo de la infancia a la adolescencia y de la exploración hacia el conocimiento ante nuevas relaciones, dan forma a cada relato. Juegos y anécdotas en el contexto de una pulpería de barrio, de esas que ya casi no quedan. El trato con los clientes, que más que clientes eran vecinos, contertulios y amigos, en un barrio con una dinámica social propia, son parte de la remembranza, también añoranza, de una raíz cercenada por la misma exigencia de transmutación continua y sin retroceso. Quien relata, como muchos de los personajes en remembranza, hace muchos años que respiran otros vientos. El barrio es recuerdo o sitio de visita ocasional, aunque ya no sean lo mismo.

La ubicación en un espacio donde lo urbano se mezcla con lo rural, le da ciertas particularidades a la vida cotidiana y a la convivencia vecinal. El trabajo toca a la chiquillada, mientras la adultez domina con el influjo de su 
responsabilidad. Algunos niños trabajan y a veces juegan, mientras el cambio social se resiste ante el peso de la tradición.

Las anécdotas rememoran vivencias, tradiciones y costumbres, muchas de las cuales hoy ni siquiera es posible imaginar, dada la transformación que han tenido nuestros barrios; particularmente por la urbanización y prolífera diversificación comercial. El consumismo, la velocidad de las transacciones y las comunicaciones, la prisa por cumplir compromisos, las redes sociales y los juegos electrónicos dominan el vivir diario de niños, jóvenes e incluso de personas adultas. Cosas de ahora que en esos años no se imaginaban, como también resulta difícil para las "güiladas" actuales, imaginar la dinámica de aquellas otras.

Las vivencias infantiles, casi juveniles, a veces se transforman en travesuras, que a su vez forjan un proceso de aprendizaje, donde las costumbres y tradiciones son vías de transmisión de valores como la honestidad, el amor al trabajo y el respeto por la individualidad, tan necesarios de mantener.

Narraciones espontáneas, que poco a poco fueron dando forma a un compendio de recuerdos que describen la vida del barrio, vista desde la esquina de una pulpería, que era centro de tertulia, encuentros, juegos y travesuras infantiles, en un ambiente abierto y de confianza propios de la época. Los recuerdos también lo son del lenguaje utilizado, donde una parte importante de los términos han sido transmutados por las demandas sociales y tecnológicas actuales. Lo son también de los espacios aledaños y citadinos, tanto al barrio como de aquellos necesarios de acudir para complementar la memoria.

Lo anterior motiva un esfuerzo por contextualizar algunos significados en notas o complementos narrativos, lo mismo que algunos datos que pueden ser poco o del todo desconocidos para algunas personas que lean estos relatos, en particular si son jóvenes o pertenecen a otras culturas, ayudando a comprender el contexto y el significado de la narración.

El relato de memoria resulta útil para acercar la época pasada y recrear los valores y tradiciones desde una perspectiva que puede ser histórica, pero también social, ambiental o cultural. 
Les invito a rememorar, revivir o conocer anécdotas de vivencias que fueron posibles. Quizá en algunas ciudades de esas que parecen pueblos, donde el paso del tiempo no es tan acelerado, queda espacio para los juegos infantiles y las tertulias del vecindario. Donde las personas se conocen y también pueden intimar y confiar unas en otras.

\section{LA LLEGADA A LA PULPERÍA}

Había iniciado el cuarto grado. Durante varias semanas mi hermana y yo habíamos caminado desde La Robert ${ }^{1}$ hasta la Pilar Jiménez. ${ }^{2}$ Habíamos estado "arrimados"3 con la tía Mayra, su esposo y sus dos hijitas, una de dos años y otra recién nacida, donde además estaban mi abuela y papá. Mi hermana y yo habíamos llegado desde diciembre, luego de finalizar las clases. Había hecho mi tercer grado en la Escuela de Villa Ligia ${ }^{4}$ de San Isidro del General. Como había estado con mi tía Angelita, ella también se quedó durante algún tiempo. Aquella casita se hizo pequeña, aunque a veces observaba al tío Memo, que era quien pagaba el alquiler, pasando desde la sala hasta la cocina, empujando el triciclo para diversión de mi primita.

Durante varios meses papá había buscado una casita que alquilar, pero que le permitiera realizar alguna ocupación, porque de otra manera... Luego de la separación tuvo que dejar la finca. El patrón algo le indemnizó. Pero pasar del trabajo de peón al de algún oficio en la ciudad no era fácil. Las posibilidades no eran muchas para él.

Recuerdo que a veces hablaban de comprar un lote y mencionaba que a 100 el metro, que a 75. Yo no entendía que era eso de a 100 el metro, que era muy caro, pero tenía algo que ver con papá o mi abuela, a quién desde que conocimos le decíamos "Abuelita". Por alguna razón, ella creía que por La

\footnotetext{
1 "La Robert" es un barrio ubicado un kilómetro al este del parque de la ciudad de Guadalupe. Así se conoce a los alrededores de un cruce hacia Sabanilla, donde se encontraba el "Abastecedor Robert".

${ }^{2}$ Escuela (de educación primaria) Pilar Jiménez, ubicada trescientos metros al norte del parque de la misma ciudad.

${ }^{3}$ Expresión que indica que se está viviendo en casa de una familia, por la facilidad o ayuda que se recibe, al permanecer en la vivienda sin incurrir en los costos por alojamiento.

${ }^{4}$ Hoy en día es uno de los barrios de esa ciudad de la Región del Pacífico Sur de Costa Rica. Pero a fines de los años 60 eran unas pocas casas, donde no había electricidad ni otros servicios públicos. Entonces se construía la carretera interamericana y ese barrio se ubica en su paso, a dos kilómetros al sureste del denominado "Centro" de la ciudad.
} 
Vasconia o San Cayetano ${ }^{5}$ algo se podía encontrar, lo que nunca ocurrió. Ella añoraba la época cuando había migrado con su esposo y su numerosa descendencia desde las montañas ubicadas entre San Ramón y Miramar, para vivir en los barrios ubicados al sur de Plaza Víquez.

Por fin un día nos trasladamos a la pulpería. Creo que llegamos con algunos catres y no se cómo, resultó que mi papá tenía su cama de madera, porque tenía que ser plana, por su accidente en la espalda. Creo que él mismo la hizo. Desde entonces la escuela nos quedaba más cerca, pues entre la casita de La Robert y el Cine Reina hay como 800 metros de diferencia.

La pulpería estaba a cien metros de ese hoy "reconvertido" cine. ${ }^{6}$ La dueña había sido una señora, doña Dora, a quien al parecer los hijos se le habían hecho grandes y le resultaba mejor vender la pulpería y vivir en una casa más cómoda. Se trasladó cerca, como a 150 metros al este. Uno de sus hijos, Alberto, se mantuvo trabajando durante un tiempo en una colchonería que estaba al frente, contiguo a la que era competencia para nosotros, otro negocio que era de pulpería y cantina, pero la colchonería era aparte.

Doña Dora dio algunos consejos a papá de "cómo atender" la pulpería, las virtudes y defectos de algunos clientes, cómo y a quiénes dar fiado, el uso de la libreta y el cuaderno. Había clientes fijos, que muy pocas veces compraban al frente, y otros que casi nunca nos comprarían. En general la relación con el vecindario era buena. En cuanto a los precios, que algunos productos se pueden rebajar para atraer clientela, así que la cocacola, que era para 60, la vendíamos a 55 céntimos, el pan a seis por peseta ${ }^{7}$ y creo que había otras "promociones". El fiar a ciertos clientes también era una forma de mejorar la clientela, pues muchos ganaban por semana. ${ }^{8}$

\footnotetext{
${ }^{5}$ Son dos de los barrios ubicados del sur en la ciudad de San José.

${ }^{6}$ En Guadalupe había tres cines. Eran populares por los precios y llegaban todas las películas que meses o semanas antes eran estrenadas en los principales cines de San José, como el Variedades, el Metropolitan y el Central. El cine Guadalupe, cuyo espacio es actualmente un parqueo, también era del dueño del Reina y ahí se pasaban las películas mexicanas. El Río, frente al parque, pasaba las películas de la "Cadena Urbini", que se estrenaban en el Variedades. Hoy ninguno sobrevive.

7 Una peseta equivalía a veinticinco céntimos de colón. Una "piña de pan", de cinco bollitos, entonces tenía un precio normal de una peseta, o sea "a cinco el bollito".

${ }^{8}$ En el año 1969 el salario semanal de un obrero de una fábrica era de entre 80 y 100 colones semanales. Según el Decreto $N^{\circ} 8$ del 17 de setiembre de 1968, que estableció los salarios mínimos vigente entre octubre de 1968 y setiembre de 1970, el salario de los peones sería de 10.70 colones diarios y el de los dependientes de 14.10. En la industria textil, un "operador de máquina" ganaba un mínimo de 13.40 diarios. En las sodas los vendedores tenían derecho a ganar como mínimo, según ese decreto, 10 colones y los saloneros 10.40 (en ese año aún no existía el hoy llamado "impuesto por servicio" del $10 \%$, que se
} 
Creo que papá tenía un dinero, pero le quedó por pagar un saldo por el "derecho de llave", q que pagó unos meses después, luego que logró "platiar"10 la finca que "había hecho" con un hermano, en las cercanías de Volcán, en Guacalito de Upala. Durante algunos días nos quedamos con abuelita, quien, cuando papá no estaba, era entonces quien se encargaba "de vender", con la ayuda mía y de mi hermana.

Era una pulpería que "tenía punto", por ser esquinera. Tales propiedades tenían mayor valor porque supuestamente favorecen la actividad comercial. Para papá era muy apropiado porque sería una forma de ganarse la vida.

A partir de entonces nos integramos como familia: papá, abuelita, mi hermana y yo. Cada quién tendría sus tareas. Mi hermana con abuelita se hacían cargo de las cuestiones de la cocina, la lavada y planchada. Yo tendría que ayudarle a papá en la atención de los clientes de la pulpería y en mantenerla ordenada y aseada. Cada mañana a las 5 am, sonaba el llamado de papá: jarriba!, jarriba! Y jalaba las cobijas. Soñoliento me levantaba, tomaba la escoba y barría toda la acera que bordeaba la casa. No recuerdo a partir de cuando papá me instruyó para que solo barriera el frente de la pulpería y un poco más hacia los lados. Luego debía barrer el piso y pasar trapo (era un "trapo'e piso"). Para que el piso quedara "impecable de limpio", debía pasarlo y lavarlo tres o cuatro veces, al menos en la parte de afuera, para dar una buena impresión a los clientes, que también madrugaban.

Había un panadero que todos los días, alrededor de las cuatro y media de la mañana, pasaba a dejar un saco de "pan francés", que así se le llamaba al que venía en "piñas" o "manos" de cinco bollitos y era de consumo popular. Eran unos sacos de papel grueso, que creo eran los mismos empaques de

cobra sobre el total de una cuenta en la mesa de un restaurante, bar o establecimiento similar). Un "Médico residente" tenía un sueldo mensual mínimo de 1600 colones. (Fuente: Oficial. Colección de Leyes y Decretos. 1968, II Semestre, Tomo I. pp. 396-415. En 1971 el salario de un "obrero especializado" sería de 27.75 colones diarios; el de un peón 17 colones. Esto según el Decreto 1740-TBS del 22 de mayo de 1971. En: Oficial. Colección de Leyes y Decretos. 1971, I Semestre, Tomo 3, p. 1016.

9 El "derecho de llave" es lo que se paga por el "punto" comercial donde se ubica el negocio, que por haber sido creado con anterioridad, requirió una inversión en recursos y trabajo, para obtener una clientela estable que sustenta la permanencia en el tiempo y la sobrevivencia del negocio, independientemente de quien sea el propietario. Para la compra se debe pagar además por los saldos de mercadería, o inventario, que se tenga al momento, que en el caso de las pulperías se puede hacer "a bulto", o sea, al cálculo aproximado o estimación "a ojo de buen cubero", de quienes hacen la transacción.

10 "Platiar", por hacer en dinero como producto de la venta. 
quintales de harina o azúcar. Mientras estacionaba el carro el señor sonaba la corneta, luego abría el cajón, sacaba el saco con nuestro encargo y lo dejaba en la puerta, para de inmediato dirigirse al siguiente punto de entrega. Papá ya lo estaba esperando, recogía el saco, se bañaba y nos levantaba.

La venta del pan era muy importante, porque "dejaba"11 el cuarenta por ciento (40\%). Con el tiempo comprendí de qué era ese porcentaje. Rápidamente se vendía casi todo, quedando una parte para el transcurso de la mañana. A veces se quedaba, pero no se gastaba ni se vendía. Abuelita los convertía en budín, ${ }^{12}$ que era muy apetecido por el vecindario, pues desde que estaba en el horno el aroma se esparcía entre la casa y la pulpería.

\section{CASAS NUEVAS Y MENOS NUEVAS}

La pulpería se ubicaba en el intermedio entre lo rural y lo urbano y entre lo pobre y lo menos pobre. Al frente, hacia el norte, las calles asfaltadas ya eran de amplio uso. Detrás, hacia el sur, la calle de tierra era mucho menos transitada. De un lado casas, algunas bien acabadas, de construcciones de block y nuevas, en medio, hacia el este y el oeste, incluyendo la pulpería, casas de madera, un tanto viejas y otras más viejas. Del otro lado, un ambiente de fincas de café, posiblemente en proceso de extinción, sobrevivía con sus peones, cuidadores, árboles de sombra y la humedad con la frescura del río.

Las casas de block estaban directamente en frente, hacia el norte de la pulpería, lo que es lo mismo: la cuadra que se extendía por detrás del cine Reina. Sus ocupantes eran casi todos de una misma familia. Algunos lotes sobrevivían como espacios donde la chiquillada de ese sector, compartía con la del sur, en juegos hasta el anochecer.

No sabía cuantos eran los núcleos familiares de los Gutiérrez, pero de la misma manera, esta era una descendencia prolija, que ocupaba casi todas las casas de esa cuadra, hasta la esquina que daba al frente de la pulpería y continuaba por la misma acera hacia el oeste. La casa esquinera, blanca con unos ornamentos de lajas, contrastaba con la de doña Carmen y de la

\footnotetext{
${ }^{11}$ Por utilidad o ganancia obtenida al vender el producto.

${ }^{12}$ Una especie de bocadillo dulce, casi siempre de forma cuadrangular, hecho de pan y cierta variedad de ingredientes según la receta personal de quien lo hace, como azúcar, vainilla, huevos y pasas.
}

ISSN: 1659-0066 
pulpería de Pascual. También el automóvil de su propietario, quien vivía con su esposa y luego una niñita, quien siempre lucía muy bien atendida por sus progenitores.

A veces los domingos se escuchaba la entonación de melodías interpretadas en piano por Benjamín, nuestro distinguido y muy respetado vecino. De cuando en cuando en las tardes o las noches, se escuchaban los acordes de una música poco conocida y nunca escuchada en el radio, acostumbrado a transmitir los programas para informar y alegrar la mañana, con amaneceres rancheros, el noticiero y "Tres Patines". De vez en cuando la señora joven nos visitaba en la búsqueda de algún producto, pero Benjamín casi nunca. Era preferida su asiduidad a la pulpería y no pocas veces, también las "aguilitas" del otro negocio de Pascual. ${ }^{13}$

Distinto era con una señora de origen alemán, cuya prole con Rodrigo llegó a cuatro hijos y una hija, todos de buen porte, educación y conciencia. Doña Luz si era una de nuestra clientas más asiduas y gustaba de las "conversonas" con papá. Desde el alto de la casa esquinera donde residían, acostumbraba venir a comprar las cosas más diversas. Sus hijos, principalmente Pablo, Oscar y Dalia, también acostumbraban visitarnos, aunque venían a su mandado y no se quedaban tertuliando.

Los lotes que había en esa cuadra cuando llegamos, luego permanecieron poco tiempo. Varias casas nuevas y bien construidas los fueron ocupando. Hacia el centro de la cuadra, una alameda se abrió dando paso a varias casitas. Al fondo se trasladó a vivir la abuelita, rodeada de toda esa chiquillada y sus hijos, nueras y yernos. De mejores ingresos, algunos de los residentes de esta parte del barrio tenían sus automóviles, los hijos asistían a colegios privados, entre ellos el Humboldt era uno de los llamativos, con transporte incluido. Se contaba que el abuelo fuera un hombre trabajador y destacado en su oficio, así como muy apreciado en la comunidad, cualidades que heredó en su descendencia.

La chiquillada Gutiérrez solían mezclarse con los carajillos del sur en los diversos juegos, pero más si se trataba de algunas incursiones en los alrededores de los cafetales y terrenos enmontados. Además tenían mayor cercanía con los pocos núcleos familiares del frente de esa acera, entre

\footnotetext{
${ }^{13}$ La etiqueta de una marca de cerveza muy popular, la "Imperial", tiene un águila.
} 
quiénes también habían algunos niños, pero éstos eran mas asiduos de incursionar en los lotes vacíos y las fincas del sur.

Entre ellos estaba Pedro, quien no era de mucho jugar bola, sino que muy a menudo pasaba con una cajita donde tenía su ajedrez. Se dirigía a entablar partidas con amigos residentes en tres de las casas de la calle de piedra al sur de la pulpería, en una los Madrigal, en otra vivían Miguel y Maritza Hernández con su mamá y en la tercera doña Adela y su hijo, quienes eran propietarios de la casa donde vivían Maritza y Miguel, y tres casitas más que eran de alquiler. Todos ellos, además de Pedro y sus hermanos eran de nuestros clientes y amigos. Las mamás de Pedro, Maritza y de los Madrigal, eran de quienes tenían libreta y cuaderno en la pulpería.

La familia de Pedro: padre, madre y dos hermanos, vivían dos casas hacia abajo, al oeste de Benjamín. Un lote que separaba ambas casas, fue ocupado con una casita muy bien presentada, cuyos residentes no eran muy conocidos. Más hacia abajo teníamos otros vecinos, quienes al parecer algo tenían que ver con la Universidad de Costa Rica y el Ministerio de Hacienda, además que los muchachos cursaban sus carreras.

Contiguo a los negocios de Pascual, pegado a la colchonería había un lote que siempre estaba enmontado. Crecían unas escobillas y unos matones rojizos. ${ }^{14}$ No era un sitio donde se jugara, sino que parecía tener basura de muebles, escombros y "chunches"15 viejos. Además no tenía acera y estaba un poco alto del nivel de la calle. Pegado a ese lote continuaba un pasadizo de cemento, separado del lote por una cerca de alambres de púas, al que se ingresaba por un portón de madera y láminas de zinc. Al fondo había unas cinco o seis casas. En dos de ellas vivían Nora, quien se hizo amiga de mi hermana, su hermano Kiko y Enriquito, un sobrinito de Nora, así como las mamás y un señor mayor, cuya relación con ellas nunca comprendí.

Luego de esa entradita, que tenía portón con aldaba, hacia el norte seguían tres casas, la primera daba a la acera y las otras estaban detrás, ingresándose por un pasadizo de tierra. Eran de varias familias, parientes entre sí. En una de ellas había vivía Ernesto, quien también era músico: timbalero. Tenía las manos duras como piedras y le gustaba andar en una hermosa moto, con unas chaquetas de cuero y medias botas, todas negras. Era moreno, alto, con

\footnotetext{
14 Matones: sinónimo en nuestros campos de arbustos.

15 "Chunche": se le dice así a casi cualquier aparato o mueble viejo, que a veces poco o nada se utiliza.
}

ISSN: $1659-0066$ 
peinado "a lo Kennedy", muy amistoso y le gustaba quedarse conversando con nosotros. Siempre que venía se compraba un paquete de rex, ${ }^{16}$ aunque

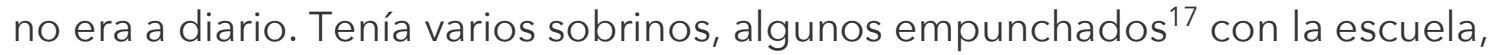
pero eran parte de las barrillas y también jugaban en la acera del frente de su casa. Como los Gutiérrez, tenían algunas bicicletas y a veces se hacían una patinetas con roles, en las que se dejaban ir desde la casa de Benjamín, aprovechando la pendiente, pasando por la de Pedro y casi hasta la siguiente esquina hacia el oeste.

Luego de las casas de donde Ernesto, hubo un taller de ebanistería, donde hacían varias clases de muebles, pero con el tiempo lo cerraron y llegaron a vivir otras personas. Creo que el taller fue abandonado o lo convirtieron en casa. El ruido de las sierras, martillos y otras máquinas dejó de escucharse. Estas no eran de nuestra clientela, sino que iban a un negocio más grande que había a la vuelta, por la calle principal, casi al frente del cruce a Moravia. Además de ese negocio, que era algo así como un abastecedor, nombre que se le daba a un negocio más grande que una pulpería, había un bar, es decir una cantina con algunas mesas y un mostrador más grande.

También una verdulería y una carnicería, donde a veces abuelita me mandaba a comprar para hacer olla de carne, además de otro negocio parecido a una pulpería, pero no muy surtido, donde también se vendían verduras y frutas. La verdulería era atendida por un señor y sus dos hijos varones, quienes vivían a 125 metros al este de la pulpería. Uno de ellos, Hernán, solía venir a la pulpería y también gustaba de las tardes con Pedro y sus amigos a las casas de la calle con piedras.

Al frente de ese bar y haciendo la esquina de ángulo obtuso del cruce a Moravia, empotrada detrás de la ferretería de "Chalo", estaba la "Sodita Guadalupe", que era algo así como un centro social, donde los fines de semana confluía bastante gente, principalmente jóvenes a disfrutar de tardes y noches bailables, con "rockola". Muchos de nuestros vecinos jóvenes solían ir ahí los viernes y sábados en las noches. No pocas veces, a más de alguno se le pasaban los tragos y pasaba rumbo a su casa bastante "entonado".

\footnotetext{
${ }^{16}$ Rex: una marca de cigarrillos, que es de "sabor" fuerte.

17 Empunchados: muy dedicados u ocupados.
} 


\section{UN BARRIO PARTICULAR}

Cien metros al sur del Cine Reina, el ambiente urbano parecía cambiar, entrelazándose con lo rural, como una frontera en donde se encontraban campesinos y citadinos. Hasta la esquina de la pulpería la calle estaba asfaltada, pero de ahí hacia el sur era de tierra. Como a otros 150 metros iniciaba lo rural: varias fincas de café se sucedían, y entre ellas serpentea el río Torres. Un puente, de esos de concreto y una vía, mas o menos de la época de don Julio Acosta ${ }^{18}$, permitía el paso de peatones y vehículos que se dirigían a Sabanilla o a las pocas casas insertas entre los cafetales.

Un poco arriba del puente, el cauce permitía algunas pozas visitadas por las "barras de carajillos". ${ }^{19}$ Ya entonces lucían contaminadas, pero eso no impedía un rato de diversión y competencias por ver quien hacía la mejor pirueta al brincar desde una piedra, el mejor clavado, quien llegaba más abajo o cruzaba la poza en cierta dirección, o duraba más en el fondo.

Como a los 50 metros al sur de la pulpería, la calle se bifurcaba para encontrarse unos 100 metros después. La parte este, tenía algo de lastre y piedra, mientras la parte oeste, donde continuaba la acera de la pulpería, era solo tierra y al fondo casi un montazal, por lo que por ahí no se transitaba y las personas casi no pasaban. En el centro de la isla formada por la bifurcación y el reencuentro de la calle, había un lote vacío, por donde se pasaba desde la calle de tierra a la de lastre. Cruzando había un terreno amplio, donde abundaba un zacate grande, en el que germinaban "lágrimas de San Pedro"20. Más al fondo este espacio se encontraba con un par de finquitas de café y hacia abajo y al sur con el río Torres. Todos esos terrenos, y la misma calle, servían de espacios donde la "catizumba de carajillos" realizaban una gran variedad de juegos: bolinchas, fútbol, quedó, "jahí vienen los moros!", trompos, escondido, papalotes.

La calle de tierra también era el lugar donde los "barrecaños", que así se les denominaba a los servidores de sanidad de la Municipalidad, amontonaban los desechos que recolectaban en las calles y caños de las cuadras cercanas, frente a las casas más humildes del barrio. Dos veces a la semana una

\footnotetext{
18 Presidente de Costa Rica entre 1920 y 1924.

19 Grupos de adolescentes y niños amigos, que comparten juegos y travesuras. Sinónimos de "güilada", "pandilla" (de uso reciente), "catizumba" y otras expresiones populares.

20 Las "lágrimas de San Pedro" son unas pelotitas verdes al inicio, que al madurar toman un tono blancuzco y café, duras, que se utilizaban para hacer collares o pulseras, o como proyectiles de cerbatana.
} 
vagoneta y un tractor llegaban a recoger los desechos. Los más conocidos eran dos barredores que siempre pasaban por la pulpería, a descansar, a almorzar en un peldaño que formaba la acera, a fumarse un cigarro o simplemente a conversar con nosotros.

Al lado este de la pulpería, cruzando la calle de tierra, había una casa esquinera sobre horcones, parecida a esas que muchos años después conocí, que se construían en las zonas bananeras, con paredes de tablones, amplio corredor y una grada al frente. Curiosamente tenía una letrina que daba a nuestro frente y un gran palo de guaba ${ }^{21}$ que le hacía sombra. Alrededor de esta casa la acera era unos centímetros más alta que del resto de casas. Tenía una cerca de alambres de púas y amapolas y la puerta principal daba al lado norte, hacia la calle de asfalto y la cantina. Debajo del piso se guarecían dos perros y algunas gallinas y patos. Su alrededor, lo que serían los espacios de antejardín, servían de patio y habían macetas colgando de tres ventanas de madera y bisagras, por donde doña Carmen, su marido, cuatro hijos y dos hijas, en las tardes se entretenían saludando y conversando con los vecinos, muchos de ellos regresando de sus trabajos. Las mujeres eran la mayor y la menor de los hijos y el marido carpintero. Ninguno de ellos era de "andar en las barrillas", aunque gustaban de quedarse conversando con nosotros. Doña Carmen era muy afable y la hija menor era de mi edad y de facciones finas.

La casa diagonal a la nuestra, en que se ubicaba la otra pulpería, también era de las más viejas. Las paredes eran de adobes. En la parte oeste estaba la puerta de la pulpería que competía con nosotros. Era atendida por doña Tere, su marido Pascual, una hija un poco mayor que mi hermana, y dos varones: Jose me llevaba un año y yo un año a Marcos. La parte de la cantina era totalmente separada de la pulpería, con una pequeña puerta al lado oeste, pegando con la pulpería y otra puerta principal al lado sur, al frente de doña Carmen.

La pulpería de doña Tere y Pascual tenía de un lado, al norte y como parte de la misma edificación, la colchonería donde trabajaba Alberto a las órdenes de un hombre maduro que reflejaba un amplio dominio de aquel oficio. Al

\footnotetext{
${ }^{21}$ Palo: sinónimo de árbol. La guaba es una fruta que se da en formas similar a una gran vainica. Hay varias especies. Unas son de color verde y gruesas y otras de color café, aplastadas y menos carnosas, pero la pulpa siempre es blanca y dulce, cubriendo las semillas, que son relativamente grandes. De éstas últimas era el árbol mencionado.
} 
lado sur la cantina, que casi siempre era atendida por Pascual con un poco de ayuda de doña Tere.

Pero esa casona aún tenía espacio para otro negocito: la zapatería remendona de Emilio, que funcionaba en un local separado por una pared gruesa al lado este. Era como un cuarto grande donde abundaban los pedazos de cuero, herramientas, un motor para lijar y emparejar las suelas, hormas, dos o tres asientos de zapatero, cuchillos y encargos de los clientes, donde los pares por arreglar parecían desacomodados y en descuido, pero Emilio sabía donde estaba cada cual. Ahí también era un centro de tertulia y lectura del periódico y revistas de caricaturas. Emilio trabajaba hasta ya entrada la noche, aunque no abría temprano y no vivía en el barrio. A veces tenía uno o dos ayudantes y junto a los muchachos mayores del barrio, armaban mucha bulla contando cuentos y anécdotas, mientras se fumaban un cigarro o escuchaban las rancheras de la tarde..$^{22}$

La entrada y salida de la colchonería era una ventana un poco más alta que ancha. Ahí se observaban a Alberto y su patrón, cosiendo los colchones de paja con un pabilo grueso y unos agujones. A veces colocaban una mesa por fuera y ahí cosían, utilizando un espacio que ampliaba la acera o un lote vacío que había a la par. A veces, en un carrito de carga, el patrón cargaba varios colchones y los llevaba a sus clientes distribuidores. A esa ventana llegaba Ana, la novia de Alberto, quien vivía a tres casas de nosotros siguiendo la acera por la calle de tierra. A veces le llevaba café y unas tortillas en las tardes. Ella vivía con sus siete hermanos, su papá, una tía de nombre Cecilia, un tío llamado Mario y era obrero en la Reyco, la abuela Nena y el abuelo José Luis, quién heredaba el apellido Calderón a toda una parentela. Vivía además un primo, también de nombre Mario, quién también laboraba en una fábrica, pero en otra ciudad y "que le hacía"23 a las reparaciones eléctricas.

En esta acera, a continuación de la casa de Ana, habitaban al menos otros seis núcleos familiares y todos eran parientes entre sí. Era como un clan, donde había tías y tíos, sobrinos y primos, pero solo una abuela y un abuelo. Los tíos y tías de Ana eran Cecilia, Joaquina, Ana, Mario, Olga y Rafael Angel. Jorge era el papá. Cada quien tenía sus hijos y vivían en casas contiguas. Rafael Angel tenía una pareja de hijos y su esposa, que también se llamaba

\footnotetext{
22 Varias emisoras tenían programación de música ranchera mexicana en las madrugadas y las tardes.

23 Quiere decir que no se dedicaba a eso, ni era su ocupación, pero sabía cómo hacer ciertas reparaciones.
}

ISSN: $1659-0066$ 
Cecilia, y nombraron igual a sus descendientes. Así que en el barrio teníamos a dos Rafael Angel Calderón y tres Cecilia Calderón. Además eran calderonistas, de esos de "hueso colorado".

Estaba además un pariente lejano, Arturo, quién cuando nosotros llegamos vivía a tres casas hacia el oeste de la pulpería. Pero luego se pasó, dando continuidad al apellido Calderón en todas esas viviendas. Era una casita de piso de tierra, que quedaba exactamente al frente al sitio donde se depositaban los desechos de los caños. También era el punto donde se terminaba la acera, ya que a partir de la casa de Arturo no la había. Hacia adentro, siguiendo al sur, eran como cinco casas, que si bien no tenían aceras, si lucían lindos jardines. De los hijos de Arturo recuerdo que eran cuatro varones y cuatro mujeres, además de su esposa, una mujer dulce y morena, de nombre Socorro.

Toda la descendencia Calderón formaban el centro de las barras, tanto de los "carajillos", como de los grandes. A veces armaban sus partidos, que no les decían de fútbol, sino simplemente "jugar bola". ${ }^{24}$ Carlillos, hermano de Ana y quién me lleva un año en edad, era uno de quienes casi siempre hacía de capitán de un equipo y Uriel, de otra familia de la acera de enfrente, era el otro capitán. Las casas de esta otra acera estaban en un terreno un poco más alto, las había de madera y algunas de concreto y lucían en mejores condiciones.

Pocos años después la casona de doña Carmen fue derribada y construyeron otra gran casa de madera, que me recordaba la que, con la ayuda de los peones, papá y el tío Olivo habían construido en la finca de Guacalito. Desapareció el palo de guaba y la letrina. También la casona de la pulpería y cantina de Pascual y doña Tere tuvo cambios, cuando la colchonería se trasladó un poco al oeste del parque de Guadalupe y Emilio dejó la zapatería. Los espacios fueron ocupados por la pulpería y amplió el uso para vivienda. El lote que también colindaba al este, luego fue adquirido por Pascual y doña Tere, quienes remodelaron y construyeron una casa grande y de alto.

\footnotetext{
${ }^{24}$ La expresión era "vamos a jugar bola", lo que se hacía con cualquier bola, ya que de fútbol, en esas
} épocas y por su costo no se veían en un partido entre "carajillos" de un barrio como el que aquí se relata.

ISSN: $1659-0066$ 


\section{VENERACIÓN A LA SANTÍSIMA ENTRE SIROPES, JABONES Y KOLAS}

La pulpería tenía dos estanterías, una en el lado largo, que era hacia el sur. Al centro del lado corto, al oeste, uno de los estantes que lucía como una mesa a un metro de altura, donde abuelita colocó una imagen de la Santísima Trinidad. Al frente un vaso de casco medio lleno con agua, al que le agregaba una onza de un aceite. Era similar a un pequeño altar. Había unas cajitas de velitas, que eran como una arandelita de cartón parafinado con un hilo grueso atravesándola. Se colocaba una velita sobre el aceite del vaso y se encendía con cuidado. Ahí permanecía la imagen a la vista de quienes llegaban al negocito, aunque no siempre encendía la velita. Como yo debía sacudir los estantes, siempre arreglaba el espacio destinado a esta veneración. A un lado, hacia la esquina con la pared norte, estaban las botellas de siropes de kola y zarza; vainilla; aceite de aguacate y vinagre; que se vendían por onzas. Se medían con unos vasitos de esos que hoy venden en los negocios de adornos y artículos para el hogar y también se usan en las cantinas para medir y servir los tragos.

Debajo estaban las cajas de los refrescos, que eran de madera. Para colocar las botellas tenían unas casillas cuadradas, que alcanzaban un poco menos de la mitad del largo de las botellas. De ahí se tomaban para enfriar en la refrigeradora o para vender al natural, o sea sin enfriar, y se colocaban los envases vacíos. Cada empresa tenía sus propias cajas y eran rotuladas con publicidad: habían las de cocas y fantas, las de pepsis y las de canada dry. Luego una de éstas introdujo la "bravo", que compitió con la fanta naranja. Las botellas se acomodaban por cada refresco, aunque los distribuidores de cocas y fantas permitían intercambiar entre ambos envases, lo mismo que los de canada dry y bravo. También vendíamos las marcas nacionales como Navarra y Cruz Blanca, así que también había zarzas y kolas, que eran más baratas que las extranjeras. Yo prefería las zarzas y luego también las "bravo". Además habían quinadas, sodas y gin, en botellitas de una cuarta, que eran de muy poca venta.

También en ese sector se tenían algunas verduras. Muy pocas, porque no era el negocio, pero a veces habían papas, tomate y culantro coyote. En los estantes de encima, más altos, se tenían unos rollos de manzanilla, que poco se vendían, pero no faltaba quien de vez en cuando anduviera buscando un rollito. Entonces se vendían rollos de la mata, que estaban secos y la gente los preparaba así, incluso con la raíz, sin diferenciar el uso de las flores. 
Del otro lado del estante, hacia el sur, era la esquina opuesta de la entrada a la pulpería. Ahí se cruzaban dos puertas, que daban una a la cocina y otra al cuarto donde dormíamos papá, mi hermana y yo. A ese lado estaban los jabones y detergentes. Había bolsas de varios tamaños y cajas de cartón de fab, ajax y otras marcas. Además betunes, cloros y potasa en envases plásticos, así como otros productos que no eran comestibles. También jabones en barra, azul y uno de coco que era blanco, que se vendían en barras enteras, medias y cuartos. Al partir el jabón blanco, que se vendía poco y era más duro que el azul, quedaban unos restos que a veces se confundían con el queso en polvo.

Encima de los siropes se colocaba el queso "bagaces" 25 , que se vendía en polvo, pero había que rayarlo al momento que el cliente lo pedía. A un lado del altarcito había un rayador, que era como un cajoncito de metal donde se introducía el queso, con un maderito especial se le hacía presión hacia abajo, contra un cilindro que era el rayador y se giraba con una palanca, de manera similar que un molino manual, recogiéndose el polvo de queso en un papel, donde se pesaba por onzas y se envolvía. Al partir el queso y al rayar quedaban unos restos, que se convertían en una golosina. Por este motivo algunas veces tomaba las boronas entre las manos y me las echaba a la boca. Pero más de una vez, pensando en el rico sabor de ese queso, me olvidaba que por ahí también se partía el jabón de coco.

La devoción a la Santísima Trinidad era tradicional en la familia de abuelita. Siempre nos "encomendaba". La Tía Angelita también mantenía al menos un cuadro similar en la sala de su casa, cerca de otro con el Ángel de la Guarda, que "siempre nos cuidaba a los niños buenos".

El sitio de la veneración era admirado por algunas vecinas devotas, que también gustaban de la disciplina de abuelita de escuchar diariamente el "Santo Rosario" a las 7 de la noche, que a veces competía con el noticiero que papá ponía a la misma hora.

${ }^{25}$ El queso "bagaces" debe su nombre a la ciudad de Bagaces, ubicada en Guanacaste, en cuyos alrededores durante el periodo colonial se producían quesos y derivados de la carne. Para conservarse el queso es bastante duro y más salado que otros, por lo que es propio para consumirse en polvo. 


\section{EL "APOLLO" 11}

La pulpería era como un centro de tertulia. Papá era "conversón" y le gustaba opinar, a veces con escepticismo y otras con bastante seguridad. Nunca dejaba de escuchar los noticieros de radio reloj, mañana, medio día y noche, con Ave María incluido26, para así estar informado. Quienes buscaban en la pulpería, no solo el lugar de abastecimiento, o de conseguir fiado, sino además de esparcimiento e intercambio de opiniones, léase de tertulia, se irían acostumbrando a sus comentarios. Tal vez la ubicación esquinera contribuía, pues buena parte de estos clientes frecuentes, gustaban de ubicarse en un rincón entre la puerta y el mostrador, desde donde se observaba hasta la calle principal de Guadalupe, además de toda persona que llegara o pasara de calle a calle.

Recuerdo un poco cuando el Apolo 11 llegó a la luna. Me aprendí para siempre los nombres de los tres astronautas. Había muchas expectativas en la gente sobre este gran acontecimiento. Cosas se decían: que todo eso era película, o que era pretender más allá de la voluntad de Dios. ¿Quién se iba a tragar ese cuento? Se sabía que en las películas todo lo hacían "de a mentiras". Otras que eran "chanchadas del demonio", o por el favor de los santos. Opiniones en un sentido y otro: que eso era imposible, que cómo era eso que los hombres pretendían ir más allá del cielo, o que si Dios lo quiere Dios lo puede y llegarán hasta allá.

Como siempre había asociado el cielo con Dios y los santos y las nubes, con el sitio donde ellos se paseaban felices, me imaginaba a los astronautas encaramados entre las nubes, pasando en su cohete por donde estaba Dios, como cuando aún más niño y en la finca que papá cuidaba en Guacalito, alguien pasaba saludando a mamá desde la calle, mientras yo observaba desde el balcón de la casa elevada sobre gruesos horcones de alrededor de dos metros de alto.

Tenía algunos recuerdos con papá y mis hermanos: cuando la noche era más oscura nos acostábamos en el potrero para observar la iluminación de las estrellas. Papá nos enseñaba las "siete cabritas" y nos decía nombres de algunas. El potrero era desolador. Un poco lejos se observaban las reses como acampando a cielo abierto, los caballos muy cerca y algunos perros

${ }^{26}$ La clásica canción "Ave María" aun es transmitida por esa emisora a las 6 am, 12 md, 6 pm y 12 mn. 
como cuidando del cantar de los cuyeos y por si acaso se acercaba "la jú"27, mientras el gran "patio de gallinas", se refugiaban en los gallineros, o en los espacios debajo del piso de la casona, o en las ramas de algunos árboles de alrededor.

Aunque no recuerdo los detalles, aquel acontecimiento me quedó grabado. Pero continué siendo más admirador de las estrellas, las galaxias y nubes estelares, que de la luna y los satélites artificiales.

En mis adentros tenía una duda ¿Habrían llegado aquellos astronautas a tocar las estrellas? ¿Habrían saludado a Dios y sus ángeles? Nuestros vecinos de al lado, que hicieron gran amistad con nosotros tenían una perrita, que se llamaba Laika, y se parecía a la cosmonauta. Pero entonces no tenía noción alguna de la carrera espacial. Años después la recordaría, cuando conocí la historia. Aunque no he vuelto a conocer otra Laika, salvo la que recientemente mi hija mayor bautizó con ese nombre.

\section{DE LA FINCA AL MOSTRADOR}

Papá había crecido roturando fincas en los alrededores de Arío, en la Península de Nicoya. Tuvo dos ciclos del campo a la ciudad, pues "de las montañas de San Ramón", donde nacieron él y casi todos sus hermanos y hermanas, se habían venido a las barreadas del sur de San José.

Los alrededores de San Cayetano y la Y Griega, entonces cafetales, los vieron cruzar hacia la escuela y en la búsqueda de horquetas para hacer flechas, jugando escondido, partidos, trompos y más de un "miche"28.

La decisión fue del abuelo, quién un día se obstinó de la vida citadina y arrancó con los tres hijos varones a nuevas tierras. Dejó a Abuelita con las cuatro mujeres y una en camino. La mayor, quien sería la tía Angelita, aunque muy joven, ya trabajaba en un famoso tramo del Mercado Central. La que seguía, luego sería la "Tía Monjita", iba, para orgullo de la familia, "muy bien

\footnotetext{
27 Esta es una creencia, sobre un animalito, llamado "jú" que acompaña a los grandes felinos en su cacería nocturna.

${ }^{28}$ Miche: por riña o pleito, generalmente con las manos y cuerpo a cuerpo, entre güilas o muchachos.
} 
encarrilada"29 en sus estudios como religiosa del Buen Pastor. Tal era la descendencia que había sobrevivido, pues como era usual en esas épocas, muchos niños "no pegaban"30 o eran víctimas de ciertas enfermedades.

En las montañas, aquellos varones hicieron amistad con otras familias. La de mamá, también eran el abuelo y una descendencia de tres hombres y cuatro mujeres. La abuela, doña Amelia, había muerto al año de haber nacido mamá. Entonces dejaron las montañas de Turrubares y fueron parte de las "oleadas de gente", que salieron hacia tierras más prometedoras, llegando finalmente a las cercanías de Manzanillo de Arío.

Para la gran mayoría la sobrevivencia era como peones, aunque también sembrando "en lo propio". A papá le gustaba la "riega de frijoles"31, el maíz, el arroz y el ganado. Al poco tiempo de haberse casado emigraron a nuevos rumbos. Luego que pasaron algún tiempo en lo que se conocía como Miravalles, Guayabo y Zapote. Por fin el Tío Juan encontró unas fincas que "se podían medir"32 y con papá se fueron metiendo por Guacalito hacia "El Volcán", sitios a los que se llegaba por una calle, de Canalete "hacia dentro", en el cantón de Upala. "Montaña adentro hicieron carriles" a una finca y sembraron algo de zacate "gigante"33, bananos y "guineos cuadrados", caña y algo más, mientras sobrevivían como peones.

Papá logró que luego de laborar por más de un año como peón en Zapote, le comisionaran el cuidado de otra finca, más que nada ganadera, en un sitio que hoy se conoce como Guacalito, en las cercanías de la "finca del volcán". El anterior "mandador"34, parece que era bueno para el chirrite ${ }^{35}$ mezclado

\footnotetext{
29 Decidida y con buena orientación. Derivado de "carril", una especie de callejón pequeño, que separa las fincas en las montañas que aún están sin labrar, pero han sido reclamadas y reconocidas como propias o inscritas por una persona.

30 Que morían a los pocos días o meses de nacidos. Se dice también del trasplante fallido de una planta o un cultivo.

31 Técnica de sembrar que consiste en "apiar el tacotal o montaña" y luego regar los frijoles de cierta manera, para que crezcan entre las enramadas de las plantas secas.

32 Se dice de tierras, que por no haber sido denunciadas, no tienen dueño, por lo que demostrando el tipo legal de "posesión", luego se pueden inscribir como propias. El denuncio también era aprovechado por "tagarotes" o personas que sin haber al menos conocido los terrenos, los "miden" y luego los inscriben legalmente, como una forma de acaparamiento de las tierras.

${ }^{33}$ Así se le llama a una especie de zacate que crece alrededor de dos metros o más.

34 Mandador: capataz o persona que cuida la finca y contrata a los peones que la trabajan, mientras el dueño, o propietario legal reside en otro lugar, generalmente una ciudad cercana o la capital.

${ }_{35}$ Chirrite: nombre popular con que se conoce al guaro, un licor costarricense hecho con dulce de caña y algún cereal como maíz o arroz, pero es ilegal, porque legalmente existe la exclusividad en la producción de este tipo de licores en la Fábrica Nacional de Licores que es estatal. La proliferación de la producción
} 
con la cutacha. ${ }^{36}$ Así que don Manuel decidió cambiarlo. El hombre se retiró hacia un lugar llamado Pata de Gallo y mantuvo una relación distante con papá, quien por las dudas, durante años anduvo "la rula a mano".

Era una finca al norte del volcán Miravalles, el que habían bordeado pasando por Río Chiquito, Naranjo y Zapote. Empotrada entre el monte más espeso de Guacalito, con llanos cubiertos de frondosos pastizales, donde algunas docenas de vacas, toros y caballos gozaban de la naturaleza, rodeados de la amenaza del tigre y el león ${ }^{37}$, serpientes y arañas ponzoñosas, pero alertados por varios perros, que también eran buenos para localizar y perseguir "tepezcuintes"38, aunque de paso y a veces, "sahínos", venados, cuzucos y con más frecuencia guatusas. Muy rara vez alguna danta. Aunque no necesariamente llegaban al "moledero"39 de mamá, para ser "arreglados" 40 . Claro que papá disfrutaba mucho más del "tepezcuinte" que de otra especie, lo que lograba de vez en cuando.

Aunque parecía lejos, muy cerca aullaban los congos, pululaban las oropéndolas y las lapas, así como los gavilanes, gorriones de colores y cuyeos $^{41}$, loras y pericos, monos colorados y carablanca, guacos ${ }^{42}$, carpinteros y sargentos ${ }^{43}$. A papá la encantaban las chorchas ${ }^{44}$ y siempre procuraba capturar alguna y cuidarla para escucharla cantar.

No faltaba que alguna colmena de jicote ${ }^{45}$ apareciera en la montaña. Luego de una "monteada"46, papá dejaba el "chopo"47 y agarraba el hacha, se iba

artesanal llevó a la creación del "resguardo fiscal", una especie de policía rural, para detectar y destruir las "chirriteras" y apresar a los fabricantes.

${ }^{36}$ Cutacha se le decía a una especie de cuchillo largo, con una vaina especial, utilizado para "pelear a machete". También había otra arma similar que se le denominaba "rula".

${ }^{37}$ En gran parte de las zonas rurales, se le dice tigre al jaguar y león al puma o león americano.

${ }^{38}$ La expresión es "tepescuinte", y no "tepezcuintle", como dice el diccionario.

${ }^{39}$ Moledero es una tabla grande o tablón grueso, utilizado en las cocinas para preparar los alimentos.

${ }^{40}$ Arreglados: pelados, lavados, destazados y cocinados, para ser consumidos apropiadamente por la familia.

${ }^{41}$ Una especie de ave, que con su canto en las noches acostumbra acompañar a los viajeros en los caminos oscuros, pasando de lado o cruzando entre las cercas, por lo que se le atribuyen ciertas cualidades mágicas.

${ }^{42}$ Guaco: una especie de gavilán cuyo canto es característico y apreciado, aunque no que cace las gallinas y otras especies de corral para alimentarse.

${ }^{43}$ El sargento macho es un pajarito muy llamativo de colores rojo y negro y la hembra es toda café.

${ }^{44}$ En las chorchas resalta el color amarillo y es parecida a ciertos canarios, pero tiene un canto particular muy llamativo.

${ }^{45}$ Especie de abeja de las montañas tropicales, con algún parecido a la africanizada, cuya miel es muy apreciada. 
con unos perros y regresaba con el panal, o a veces con un tronco al hombro, que abría al medio y con mamá sacaban la miel y algo de cera, luego lo amarraba y lo dejaba colgando de un horcón. Con el tiempo y un poco de suerte, las abejas de nuevo hacían lo suficiente como para "cosecharle" una olla de miel, de la que con unas tres hojas de limón dulce, mamá nos servía en una tacita o plato.

Había una casa con piso de tierra, grande, vieja y con techo de hojas de palmitos, partes de zinc y otras de tablas. Pero luego con ayuda del tío Olivo, el hermano mayor de mamá y quien conocía de la carpintería, con algunos peones construyeron una casona de horcones tan altos, que debajo se podían acomodar y ensillar varios caballos, tener los chanchos o cualquier otro animal al cuidado y en seco. También se guardaban los yugos, hachas, machetes, albardas, sogas, jáquimas, espuelas, sacos de sal para el ganado, molejones y estañones. Había encierros para cuando las chanchas tenían cría, para cuidar algunos terneros o alguna vaca enferma. Arriba, contiguo a la grada y a un lado de la puerta, un "balaú" al descubierto y otro más seguro, tipo "carabina" 48 , envuelto y a la mano. Esa casa se hizo con la madera de árboles que estaban a no menos de cien metros entre la espesura de la montaña. Solo de entonces es que recuerdo algún uso de sierras, pues lo demás era solo hacha.

En la quebrada Guacalito era donde mamá lavaba la ropa, con jabón azul y a golpe de piedra si estaba muy curtida. ${ }^{49}$ Había una pequeña poza donde nos podíamos bañar. Confluía en el río del mismo nombre, con pozas donde papá se podía consumir y pasar de lado a lado, luego de pescar algunos guapotes o barbudos. ${ }^{50}$ En la misma poza donde mamá lavaba y unos metros más arriba, estaban las cuevas de cangrejos donde papá escondía las botellas de chirrite, que nunca le faltaban.

El cuido del ganado se combinaba con la siembre y cosecha de frijoles y maíz. Algunas veces de arroz, que al parecer no pegó mucho en la zona, pues solo recuerdo una recolección: se utilizaban unas cortadoras de mano, que

\footnotetext{
${ }^{46}$ Monteada: ir de cacería. La persona va sola, o acompañada de otras, casi siempre con perros.

${ }^{47}$ Chopo: se le dice así a un tipo de rifle pequeño, de bajo calibre y de un solo proyectil, utilizado para protección y cacería en las zonas rurales.

48 A un tipo de "chopo" también se le dice "balaú" por la bala o proyectil que usa. La carabina puede usarse con varios "tiros" o proyectiles a la vez.

${ }^{49}$ Curtida: muy sucia o "embarrialada", o sucia por el barro.

50 Especies de peces comestibles.
} 
tenían unas hojas que se agarraban sobre un mango con una coyunda, que al hacer un movimiento cortaba, quedando el rollo de espigas en la mano.

La recolección de frijoles y maíz se distribuía para la casa y la mayor parte era sacada por don Manuel, si el verano era bueno en camiones, si no en caballos. Además para el consumo se sembraba malanga, chamol y tiquisque. Había árboles de varias especies de limones ácidos (criollos) y dulces, naranjas dulces, agrias y malagueñas, guabas, caimitos, zapotes, aguacates. Silvestres crecían las moras y unos puños de tomatales, de unos que parecían bolinchas rojas, pero que se comían en puños, agarrándolos directamente de las matas y a la boca.

Luego se introdujeron los chanchos, que eran nuestros (no de don Manuel). Se cuidaban con bananos que se cosechaban de la finca del Volcán. Recuerdo que con frecuencia mamá hacía una especie de "atol", por llamarle de alguna forma, preparado a mano con bananos o cuadrados maduros, o guineos verdes sancochados, desmenuzados en agua mezclada con desperdicios de comida, leche agria, suero de quesos o lo que hubiera, que servía en una gran batea con forma de canoa hecha de un tronco grueso, donde de quince a treinta animalitos, algunos más rellenos que otros, se amontonaban hasta dejar limpio y quedar saciados.

Para abastecerse de agua al inicio había que "jalarla"51 en baldes y al hombro desde la quebrada. También se recolectada de lluvia en varios estañones, como se hacía en la "casa vieja". Luego papá se encargó de que se obtuviera de las fuentes subterráneas, con un pozo de algunos metros de profundidad, casi en el patio, del que nunca faltaba. Tiempo después apareció con unos grandes tubos y una máquina roja, hizo otro pozo con un piso para cubrirlo y con la ayuda de mamá y un peón colocó la bomba, que con una palanca manual "jalaba" un enorme chorro, con el que bastaba y sobraba en comodidad para todas las necesidades.

Pero en las cercanías no había escuela. Era en Canalete donde durante dos o tres meses, llegaba alguna maestra y luego se iba. En San José la familia de papá: las tías y abuelita, insistían en que: "ilos chiquitos tienen que ir a la escuela!". Así que al cumplir la edad mi hermana primero y yo al año siguiente, éramos traídos a donde abuelita, o alguna de las tías, para ir cada año a la escuela. Así estuve el primero en Ipis y el segundo en la Pilar Jiménez

\footnotetext{
51 Jalar: por acarrear.
} 
de Guadalupe, de donde recuerdo a la Niña "Deysi" y al director don Augusto.

Estando en tercer grado, en Villa Ligia de San Isidro del General, mamá por fin se decidió a irse para no regresar. Primero a la protección de sus dos hermanos varones, quienes también habían llegado a Guacalito "haciendo fincas" detrás de papá. Luego ella emigró donde la hermana mayor en Golfito. Papá no tuvo más remedio que venirse de nuevo para San José. Un accidente "volteando"52 para la "tapa de frijoles", le ocasionó una lesión en la espalda y desde entonces debía tener cuidado al montar y al amarrar ganado. Ya no podía trabajar igual y tampoco estaba dispuesto a "hacerse de otra mujer", pues él estaba "casado por la iglesia".

La llegada a la pulpería significó en parte un ideal de actividad, tanto para él como para abuelita, pero en la que no tenía experiencia, salvo la comercialización de las pocas cosechas y las ventas que de niño hizo, de los productos caseros que hacía abuelita. Una verdulería que tuvo el abuelo no había sido exitosa y los chiquillos de entonces eran poco lo que participaban, aunque sí vendían las empanadas, prestiños, tamal asado, budines y quequitos en los barrios y los alrededores de las plazas de fútbol. Así que el poco conocimiento sobre el manejo de la pulpería lo aportaba Abuelita, pues en su momento había tenido "un negocito" en la ciudadela Rodrigo Facio de Ipis, donde la Tía Angelita logró adquirir una casita financiada por el INVU, por la que durante años pagó quince colones mensuales.

Acostumbrado a la voltea a "pura hacha", el amarre de ganado, las jornadas de castración de toretes y chanchas, curas de tórsalos y heridas de las bestias y ganado, yuntas de bueyes, carreras detrás de los perros y el "tepezcuinte" en la montaña, "piladas"53 de arroz, "aporrea" y "ventea"54 de frijoles, papá se fue adaptando a un estilo distinto de trabajo.

\footnotetext{
52 Voltear: cortar los árboles dentro de la montaña.

${ }^{53}$ Pilar arroz: golpear una cantidad de arroz en granza o espiga en el pilón, una forma de recipiente hecho con un tronco grueso de madera dura, que a manera de mortero, sirve para el golpeteo continuo hasta desgranzar o quitar la cáscara o granza al arroz.

${ }^{54}$ Aporrear y ventear los frijoles: técnica para quitar la cáscara del grano en las vainicas en rollos o puños, que luego de recoger del frijolar al secarse las matas, se amontona sobre un toldo y con una varilla larga se golpea y luego se separan las pajas y se "ventea", esto es alzar y hacer viento con otro instrumento, para limpiar totalmente el grano. El arroz también se "ventea" en el pilón, sacándosele la granza y granitos quebrados, que es aprovechado por las aves de corral o los chanchos.
} 
Siempre añoraba regresar a los potreros y el ganado, aunque sin recordar que alguna vez un novillo lo lanzara a tres o cuatro metros de una patada, una vaca brava lo levantara sobre las cercas para no dejarse quitar la cría, o que uno de estos animales o un potro "endemoniado" 55 , lo arrastrara mientras sostenía la soga de la cintura. Pero esa intención se quedó en la utopía, el cuidado de Abuelita fue su religión y luego procuró lo mismo con la Tía Angelita, aunque para entonces ya la pulpería "había pasado a la historia".

\section{MÁS AL SUR}

El puente del Torres está a casi cuatrocientos metros desde la esquina de la pulpería. Se bajan como ciento cincuenta metros y la calle dobla hacia el este. A la derecha un cafetal y a la izquierda árboles sosteniendo los muros de tierra. La sombra crea una sensación de frescura. Pero antes de llegar al puente, a la derecha, había algunas casas levantadas con horcones al borde del río. En una de ellas vivían Ramón, Marta y sus tres hijas. En la que continuaba una prima de Marta, también con tres hijas. Luego había como cuatro o cinco viviendas más, todas bastante humildes de madera y otros materiales. Con Ramón y Marta hicimos amistad. Eran personas muy "tuanis", ${ }^{56}$ humildes pero muy trabajadoras y siempre optimistas y amables, aunque no omitían utilizar el lenguaje que fuera necesario para expresar alguna verdad.

Ramón pasaba con frecuencia a la pulpería, al regreso de su trabajo, casi siempre después de las siete de la noche y las tardes de los sábados. Se quedaba contando historias con papá o echando "rajonadas", ${ }^{7}$ chistes y bromas. A veces se daba una vuelta, por un rato, a la cantina de Pascual.

A mano derecha, poco antes de llegar a estas casas se levantaba una pared hecha con tablones, que era de una construcción similar a un bodegón, pegada y casi como parte del cafetal. Tenía dos portones grandes, donde podían ingresar y salir a la vez camiones grandes. De ahí provenía un hedor que congestionaba la respiración para quien no estuviera acostumbrado a soportarlo. Aunque no me ocasionaba asco, daba una sensación de mucho

\footnotetext{
55 Por toro bravío.

56 Por "buena onda" o "pura vida", amables, simpáticas y amigables.

57 Rajonada: calificación de expresiones que consideradas comúnmente exageran una capacidad o habilidad de una persona: "No seás rajón" se dice en "tico", "¿quién te lo va a creer?" "iQue se lo crea tu abuela!"
}

ISSN: 1659-0066 
malestar. Era penetrante, como el olor de eucalipto o alcanfor, pero muy desagradable. Dejaba la sensación hasta mucho rato después de inhalarlo. Recordarlo era como revivirlo hasta sentir el malestar. Cada vez que pasaba por ahí deseaba no tener órganos nasales. Incluso sentía algo feo en los ojos y la boca. Deseaba salir espantado para no sentir aquello. Era la curtiembre de don Fernando. Ahí se procesaban las pieles de vacas, y no sé si de otros animales, para convertirlas en materia prima de cueros para diversos usos.

Una casa de regular tamaño, que lucía un poco vieja, de madera y una cerca de alambre de púas formando un pequeño jardín alrededor, hacía guardia entre los dos portones. Nunca supe quienes eran las personas que vivían en esa casa. Estaba de frente en dirección de la calle hacia el río, en un punto donde se desvía un poco hacia la izquierda. Uno de los grandes portones, era como el punto de llegada a la parte baja de la calle. El otro estaba después de esa casa, por un pequeño callejón que se formaba con las casas vecinas de Ramón, en un nivel más bajo. Pero parte de la pared de la curtiembre tenía entradas a unas habitaciones que podrían ser oficinas, o estaban ocupadas por personas inquilinas de don Fernando. En una de estas, subiendo unas gradas y casi al nivel de un tercer piso, llegó a vivir don Abel, un señor bajito y delgado, quién también se hizo amigo de papá, aunque su esposa, también bajita, pocas veces se le veía en la pulpería, o al menos salir por el barrio.

Por entre los portones y en las orillas de las paredes, se observaban cortezas apiladas de una madera roja, que se utilizaba en las mezclas que hacían para el curtido de las pieles. Desde la calle se observaban una serie de tinas rectangulares, construidas en concreto, que parecían pequeñas piscinas casi pegadas entre sí, donde varios operarios jóvenes tiraban de las pieles. Utilizaban unas varas grandes, como de más de dos metros, con un gancho que ensartaban en los bordes de cada piel. De pie hacían equilibrio entre los ángulos, batiendo las pieles en una mezcla rojiza o grisácea y un poco espesa.

Los trabajadores debían estar moviendo las pieles y pasándolas de un recipiente a otros. También se observaban unas herramientas parecidas a cuchillos, pero con dos mangos, con las que se quitaban restos de las pieles, las "carnasas", limpiándolas antes de pasarlas al curtido. A veces se escuchaba el golpeteo estruendoso de una máquina utilizada para machacar, 
tenía un brazo con algo así como un rodillo, que se abría y martillaba sobre los cueros ya secos y con el color rojizo que es característico.

En todo el olor era insoportable y se sentía a más de cien metros alrededor, a menos que la posición fuera favorable con el viento. Salvo aquellas humildes casitas, la curtiembre era una construcción aislada, en medio del cafetal, a orillas del río donde seguramente caía gran parte de los restos del curtido, proveyendo además el agua que se requería.

Estas pieles ya curtidas me eran muy conocidas. En su zapatería, el Tío Juan siempre tenía una o dos enteras, enrolladas. Siempre me llamó la atención que en una esquina tenían un corte, que resultó ser la perforación utilizada para enganchar y tirar durante el proceso de curtido. La novedad era conocer que había un trajín para que tomaran esa forma y color. Así llegué a concluir finalmente, que el pellejo de las pobres vacas llegaba a convertirse en suela de zapatos. Aunque la suela en rollos, para mi no tenía un olor desagradable, el proceso para llegar hasta esa forma sí que lo era, y bastante.

Don Fernando pasaba todas las mañanas en su camioncito para la curtiembre. No era residente del barrio. De vez en cuando entraban camiones cargados con las pieles para curtir. También de la misma manera salía don Fernando con su camioncito, lleno de pieles enrolladas, que seguro ya tenía colocadas para su realización mercantil. También entraban camiones un poco más grandes llenos de cascarones, de esos rojos, que eran materia prima para la curtida, aunque nunca supe como es que las utilizan. Solo conocí lo poco que veía desde los portones ... iy el olor! ... Seguro no tenía ánimo de averiguar mucho, sino de pasar lo más ligero posible.

Casi todos los operarios de la curtiembre eran jóvenes. Entre ellos habían tres hermanos: Licho, Celín y Alberto. Ellos vivían más adelante, luego del puente, más cerca del centro de Sabanilla, por donde hoy se ubican las instalaciones deportivas de la Universidad de Costa Rica. Eran clientes fijos de la pulpería. Regularmente, los viernes en las noches y a veces los sábados o domingos en las tardes, salían un tanto "catrineados", impecablemente peinados con glostora o brillantina y sus camisas bien planchadas. Su trabajo les daba ciertas ventajas. Siempre lucían saludables y de buen porte, con cuerpos esculpidos como de gimnastas o levantadores de pesas. Pasaban a comprarse unas mentas, alguna golosina u otro producto. A su regreso en las noches también pasaban a llevar algún abarrote. No fumaban. Eran serios y 
educados. De igual manera procurábamos ser amables con ellos, teniendo además la consideración, de que los pobres cargaban en sus cuerpos el mismo olor de la curtiembre, por lo que siempre deseaba que compraran lo que requerían, pero que no se quedaran a tertuliar.

\section{LOS SUPLIDORES: HELADOS, DIADEMAS Y DULCE DE LECHE}

Con el tiempo nos fuimos familiarizando con los "agentes", que eran vendedores que abastecían de gran variedad de abarrotes a las pulperías. Además estaban los distribuidores de ciertas marcas como "gallito", "del campo" y "jacks", que pasaban regularmente. Algunos de ellos ya tenían su programa semanal o mensual, incluso diario, desde los tiempos de doña Dora. Entre los más usuales estaba la "dos pinos", que tenía distribuidores de leche, que repartían diariamente, con unas canastas metálicas con doce botellas de vidrio cuadradas, con la marca impresa en rojo y el logotipo muy propio.

Esas botellas las conocía desde que viví en Santa Cecilia con la Tía Mayra. Entonces estaba en segundo grado en la Pilar Jiménez. Los repartidores de la "dos pinos" pasaban todos los días por los barrios, haciendo las entregas según hubiera sido encargado en cada casa. Dejaban las botellas al pie de las puertas, donde recogían a cambio los envases (botellas) vacíos. Era distintivo el sonido que hacían, corriendo y brincando las gradas de las aceras o de los mismos camiones, mientras cargaban las canastas de botellas vacías, procurando hacerlo lo más pronto posible para cumplir el recorrido.

Mi tía compraba dos botellas de tapa roja, que eran en las que se formaba una nata por ser leche sin descremar. Parte de la leche la daba en chupones a la primogénita, muy chineada por el Tío Memo, pero además me preparaba un rico atol de avena, dulce y bastante espeso que disfrutaba en las tardes o noches.

Otras botellas, si mal no recuerdo de tapa verde, eran de leche descremada. Las tapas eran de un cartoncito delgado especial, como parafinado, con el logotipo de la empresa "cooperativa", que se pegaba y ajustaba a la forma y ancho de la boca o pico de la botella. Las tapas en realidad eran blancas con los logotipos de color, pero se les decía "de tapa roja" o "de tapa verde". 
Por nuestro barrio no pasaban haciendo esa distribución, que con el tiempo desapareció y solo distribuían en las pulperías. Con los años las famosas botellas cuadradas desaparecieron, dando paso primero a unas bolsas plásticas, a las que luego agregaron un estuche de plástico duro para sostenerlas una vez abiertas. Se generaban problemas porque a veces las bolsas se reventaban en los camiones y jse hacían unos regueros ... !, que además del desperdicio, seguro ocasionaban otros inconvenientes. El caso es que las bolsas desaparecieron junto con los estuches que pretendieron "remendar" el asunto. Introdujeron las cajas de cartón, aunque entonces no existía el "tetrabrik.

La "dos pinos" también tenía repartidores de helados, que eran unos camiones especiales, como congeladores rodantes, con tapas que cerraban muy herméticos y que al abrir brotaba el gas que mantenía bien fríos los helados. Pasaban como cada quince o veintidós días. Dejábamos chocoletas y cremoletas, que venían en unas cajas de cartón delgado de unas veinticinco unidades. También algunos de cajitas pequeñas, con sus paletitas de madera en un estuchito plástico con la leyenda de la marca en verde. Las cremoletas eran de tres sabores y las cajitas de ron con pasas, vainilla, fresa y chocolate. Recuerdo que a la gente les gustaban más de ron con pasas. También había tamaños más grandes, pero dejábamos poco, pues poco se vendían. Años después introdujeron el "kronchy krisp", no recuerdo la escritura en inglés, que al inicio tuvieron mucha novedad, pero luego disminuyó la demanda aunque siempre muy apetecidos por su sabor, con maní entre el chocolate y el helado de crema dentro del cono azucarado. Pero en esa época el chocolate frío del "cronchi" no era tan duro como los de ahora y tenía mejor sabor.

En la pulpería íbamos avanzando, pues se compró un segundo congelador, además de la refrigeradora. Se introdujo la venta de hielo, más variedad de helados, se tenían los chocobananos y se podían enfriar mejor los refrescos gaseosos.

Con el tiempo aparecieron algunos competidores de la "dos pinos", que no duraban mucho, uno de ellos fue el de "helados león", que vendían helados de paleta y unos como redondos de sabores. Pero competían con los helados de palillo que hacíamos en la casa, que de todas maneras eran preferidos por la güilada. 
Papá daba mucha atención a los agentes. Debía tener cuidado con la mercadería que compraba, ya que pocas veces se dejaba en consignación, o sea para probar la venta, sin cobrar hasta la siguiente visita, cuando se decidía si continuaba con un producto o no. Así que debía calcular cuanto se podría vender. También tenía que distribuir el efectivo disponible entre las diversas opciones para surtir la pulpería. Le dedicaba su rato a la atención de los agentes y mi hermana y yo debíamos estar atentos con los clientes.

Uno de los agentes nuevos que tenía su ruta con nosotros era Sandí, un señor joven vecino de Ipis. Cuando inició su ruta también pasaba donde Pascual, pero luego dejó de hacerlo. Creo que otros suplidores tenían camiones más grandes, que no pasaban donde nosotros. Sandí tenía un camión mediano y cerrado, donde llevaba los más diversos abarrotes, como latería de atunes, sardinas, jugos, papel higiénico, toallas sanitarias, detergentes, jabones de baño, azul, amarillo y veteado, navajillas, algunos confites envueltos y muchos artículos más. Siempre pasaba los lunes en la mañana. Papá dedicaba un buen rato a la atención de Sandí, quien no pocas veces llevaba nuevos productos y algunos los dejaba en consignación.

Recuerdo otro señor que pasaba con una maleta de cuero tipo médico en una mano y a veces con una especie de saco, que cargaba al hombro con la otra mano. Iba a pie aunque ya era mayor, bajito, un tanto grueso, desgarbado y de voz ronca y forzada. Usaba de esos anteojos que hacen parecer los ojos del tamaño del lente, lo que le daba un aspecto particular, más cuando se agachaba para sacar algún artículo para mostrarlo. Pasaba cada quince o veintidós días y no tenía regularidad, porque a veces se perdía por alrededor de dos o tres meses y de pronto aparecía. En sus cargas llevaba una gran variedad de artículos de bazar: agujas, tijeras, diademas, ligas, tajadores, prensas de pelo, medias de "nylon" de mujer, lápices, peines. Así que en buena parte se encargaba de abastecer nuestra urna de bazar, acompañando los tejidos hechos por la mano de abuelita. Años después, a veces reconocí a este señor en San José, con su maletín a cuestas.

Una vez pasó un señor un poco moreno, de estatura mediana y muy bien presentado. También "de a pie", con una caja de cartón al hombro. Tenía un acento que no era familiar, pero de voz muy amable. De palabra convincente, nos ofrecía un producto novedoso, de exquisito y delicado sabor. Empacado en recipientes pequeños de un cartoncito o plástico un poco transparente, se acompañaba de una cucharita pequeña. Tenía un color parecido al caramelo 
de leche gallito, pero era como un atol muy espeso, que se podía comer solo o untar por ejemplo, en galletas o al gusto: era el "dulce de leche". El señor dio a papá una prueba de muestra, para lo que cargaba galletas de tipo "sodas". Nos pareció bueno: tenía muy buen sabor, así que dejó en consignación varias unidades del producto, para pasar quince días después. Indicó el posible precio y la utilidad que se obtendría. Papá lo colocó a la vista, junto a los exhibidores de cigarrillos y luego lo ofrecíamos como novedad a la clientela; tenemos "dulce de leche", "¡como que dulce de leche!", "este es, tiene que probarlo". Hubo mucha aceptación y se fue vendiendo. El señor continuó pasando y siempre se vendía, aunque lo dejaba en consignación.

Otros agentes fueron apareciendo, haciendo su ruta incluyendo nuestra pulpería. Sin embargo. Aunque buena parte de la mercadería no había que adquirirla en los almacenes, como latería y jabones, siempre había que ir a San José, al menos dos veces por semana.

\section{UNA PLAZA PÚBLICA}

La campaña electoral no era gran motivo de conversona en la pulpería. Papá siempre evitaba identificarse con cualquiera de los candidatos, aunque siempre iba a votar, pero "sin dar el color". ¿Por quién iba a votar? "Diay, por el que quiere ser presidente". Nadie supo nunca por quien votaba, pero siempre lo hizo. En todo caso en el barrio no había mucho interés por las campañas electorales o por sus candidatos, ni se sentía en las conversaciones o se veían vecinos identificados mediante banderas u otros distintivos. Esto a pesar de la continua conversación sobre los problemas nacionales y ciertos acontecimientos de otras partes del mundo.

Los activistas de los partidos a veces pasaban por el barrio, con altavoces llamando a votar por sus candidatos y repartiendo banderas, que casi siempre eran entregadas a parte de la "güilada", quienes hacían algún alboroto corriendo y agitando las banderas. Entonces quienes había recogido de otros partidos traían las que tenían guardadas y armaban trifulcas haciéndolo barra a tal o cual partido o candidato. Pero luego el entusiasmo desaparecía. 
A pocos días del año nuevo, había concluido con éxito mi cuarto grado. El alboroto: "Tacones", sobrenombre con que a veces se nombraba al caudillo don José Figueres Ferrer, iba a llegar esa noche a Guadalupe. ¿Y donde iba a ser? ahí por la calle real, "al lado acá de la iglesia". El entusiasmo y la bulla que ocasionó la noticia, me animaron a pedir permiso para ir a ver.

Para mi, muy escaso el significado de aquello. Pero tenía curiosidad. Serían algo así como las seis y media, recuerdo que estaba un poco oscuro y había un montón de gente, pero casi nadie del barrio y menos de la güilada. Tampoco pasaban carros ni otros vehículos. La hicieron frente a una casa que me parecía enorme, que tenía una gran araucaria en el también espacioso jardín. Estuve un rato pasando de un lado al otro. Papá me había dicho que no me metiera mucho. Empezó la animación y luego los discursos. El gran orador, el más esperado, entonó el mensaje más importante, del cual no recuerdo nada. En alguna parte estuvieron repartiendo banderas. Llegué a la casa haciendo bulla con una de plástico, que seguro alguien me obsequió.

Para el día de las votaciones papá realizó el viaje: aún estaba inscrito en Upala y se pegó un "avionetazo". ${ }^{58}$ No recuerdo si el viaje fue por varios días. ¿Por quién votó? ¡Por el que le manché la nariz! A diferencia, la tía Angelita "no escondía su color" y siempre hablaba maravillas del Doctor. ${ }^{59}$

\section{ENTRE AGUJAS, ESCARPINES Y LA COCINA}

Abuelita hacía escarpines y otras prendas tejidas para bebés, como abrigos, ponchos (que también llamaba estolas), bufandas, tapetes, guantes y cobijitas. Supongo que los ponchos los aprendió a hacer en una de sus estadías con dos de mis tías, que vivían en Guatemala. Algunas prendas las exhibía en la ventana de su cuarto, ubicado detrás de la pulpería y que daba a la calle de tierra, al lado este de la casa. Con el tiempo se compró un mostrador especial, casi todo de vidrio, en el que se colocaron los artículos

\footnotetext{
${ }^{58}$ Para el día de las votaciones, los partidos políticos disponían de una parte del presupuesto que les otorga el fisco, para el transporte de los votantes a cualquier lugar del país de manera gratuita. Con el humor propio del tico, la expresión "avionetazo", a manera de sorna, se utiliza por el uso indebido de una avioneta del Ministerio de Seguridad Pública, que hace algunos años hizo una diputada por la provincia de Guanacaste, cuyo viaje era para asistir a dar apoyo a los partidarios de su tendencia dentro del partido político gobernante, con motivo de una asamblea cantonal. Aunque su explicación pública fue la de fines comunales, una gran parte del pueblo "no se tragó el cuento".

${ }^{59}$ Así se le llamaba por muchos de sus partidarios al Doctor Rafael Ángel Calderón Guardia.
} 
de bazar, como agujas, broches, diademas, tijeras, colillas, papel de regalo, cuadernos, lápices, transportadores y demás. Ahí se colocaban de vez en cuando algunas de las prendas hechas por abuelita. No faltaba algún cliente de poca frecuencia que se llevara alguna, ya que entre el vecindario no era mucha la demanda.

Cuando papá salía y nos quedábamos con abuelita, ella a veces "atendía" (a los clientes). En los primeros tiempos era mi hermana quien la apoyaba más. Luego yo fui ganando práctica. Abuelita se sentaba en una silla con brazos que pegaba con una ventana que también daba al lado este, desde donde por la puerta, se podía contemplar hasta la esquina de la calle principal de Guadalupe. Se divisaban las personas que se bajaban en la parada de buses y venían para el barrio. Ella se "arrecostaba" un poco de un brazo, tomaba un par de agujas de tejer, y a darle y darle, iba formando las distintas prendas. De vez en cuando se enderezaba, levantaba la vista y por los bifocales contemplaba hacia la acera, hacia la esquina del cine o a la pulpería de enfrente, respiraba hondo y continuaba tejiendo.

A veces me quedaba mirándole las manos, tratando de ver como era que iba acomodando aquellos hilos, que a veces eran gruesos y otras más delgados, combinando los colores y pegando las partes. Otras veces usaba solo una aguja, según la prenda que estaba haciendo y el hilo requerido. Le ocurría que de pronto tomaba la aguja, torcía un poco la cara haciendo como cierto desgano o se reía, la desenganchaba, tomaba lo que había tejido y lo jalaba, enrollando de nuevo el hilo o haciendo un puñito, mientras deshacía lo que había tejido. Luego volvía a empezar. En esta ocupación se pasaba horas, a veces lo hacía en otra silla en el rincón cerca de la puerta hacia la cocina, pero casi siempre era en su cama. Su presencia en la pulpería durante esas horas, era para hacer sentir a una persona mayor en el lugar, así como de vigilar que no fuéramos a hacer alguna "diablura".

Abuelita tenía problemas de audición: de un oído escuchaba poco y del otro casi nada. Por eso generalmente no le entendía bien a los clientes y debíamos estar al cuidado, para que no se preocupara por la atención. Utilizaba unos audífonos que le ayudaban, pero a veces no se regulaban bien y de pronto reclamaba porque el radio tenía volumen muy alto, o se quejaba del ruido de los "carajillos" en la acera o la calle. El aparatito a veces hacía un pitido y ella hacía un gesto de desagrado o dolor, se lo quitaba, le movía 
unas palanquitas hasta que dejaba de sonar y se lo volvía a colocar. De todas maneras siempre había que hablarle de cerca y del lado de su mejor oído.

Además de los escarpines y los abriguitos, otra especialidad de abuelita era el budín. Nunca participé en esa tarea, sino que eran mi hermana y papá quienes a veces la ayudaban. Cuando había, tomaban el pan que se había quedado de varios días, del "francés" y del dulce. Lo mojaban en unas ollas y lo desmenuzaban, formando como una masa, le hacían otros arreglos con dulce, azúcar y otros ingredientes y se horneaba en unas bandejas. Salía el budín, que se colocaba en una parte especial de uno de los mostradores, se ofrecía a los clientes y el mismo olor provocaba que en "un santiamén" se vendiera.

Otra ocupación casera eran los helados de palillo. Al inicio se usaban unos palillos redondos parecidos a los de dientes, pero luego se utilizaron unos cuadrados, que eran bastante más gruesos y no se quebraban. Se hacían de natilla, los más apetecidos y más caros, también de leche agria, que a veces se preparaban con sirope de kola, de crema, de banano, de coco y otros. Se usaban unas bandejitas con unos cuadritos armados de metal, que cuando estaban listos se jalaba una palanquita y los cubitos de helados se separaban. Si no había ese implemento, simplemente se cortaban con un cuchillo y se insertaban los palillos. Entonces se ponía un rotulito en la ventana para ofrecerlos. Los "carajillos" eran quienes más los compraban, para aplacar el calor de los juegos de bola, quedó o de policías y ladrones.

Una tía que vivía en Guatemala, en una de sus visitas introdujo el "chocobanano". Ella sabía como preparar el cacao. Se partían los bananos maduros en dos trozos o mitades, se les introducía un palillo y se metían en cierto orden en el congelador. Cuando estaban congelados, se tomaban del palillo, igual que si fuera un helado y se hundía en la mezcla de cacao caliente, que se endurecía con el frío formando algo parecido a una chocoleta, ${ }^{60}$ con la forma de una mitad de banano. Se ordenaban y se colocaban en el congelador. La gente fue conociendo poco a poco el nuevo producto y se vendía bastante.

Abuelita se preocupaba además por la presentación de la pulpería, procurando que aprendiéramos como mantenerla atractiva para los clientes:

60 Una especie de helado de paleta de la empresa lechera "Cooperativa Dos Pinos", hecho de crema dulce cubierto por una capa de chocolate.

ISSN: 1659-0066 
bien presentada y ordenada. Siempre buscaba "hacer el cinquito". ${ }^{61}$ En años anteriores había tenido algunos "negocitos", pues debió lidiar con la crianza de quienes fueron mis tías, apoyando los ingresos que ellas podían generar. Una forma eran los helados, diversos productos de repostería, como budín, prestiños, quequitos, pan de leche, tamal asado, tamales de cerdo en la época navideña. Por supuesto que se debían tener ciertas máquinas, como una refrigeradora y una cocina con horno.

Así que una de las primeras compras que se hicieron fue la "refri", pues al inicio solo había un congelador. Esto permitió disponer mejor de refrescos fríos y helados de palillo. Abuelita decía que con estos helados debía pagarse la "refri". Con el tiempo vino una cocina eléctrica con horno y de vez en cuando hacía pan de leche, el budín y otras recetas que bien conocía. Los quequitos algunos clientes les llamaban "tapones", por la forma que tenían. Eran productos bastante apetecidos. En muy pocas ocasiones hacía prestiños o tamal asado. Así que esos productos complementaban la repostería en el mostrador. También hacía variar la oferta de helados, complementando los de la "dos pinos", que en esa época tenía poca variedad de productos.

\section{UNA CASA CON PULPERÍA Y OTROS NEGOCIOS}

Cierta tradición familiar se tenía con las pulperías y otros negocios en los barrios. Abuelita había sobrevivido y en parte criado a sus hijas, con la venta de tejidos y panes hechos por sus manos. Cuando me correspondió el primer grado, fue al cuidado de ella que asistí a la Escuela de la ciudadela Rodrigo Facio de lpis.

Mi tío Juan también había regresado a la ciudad, después de bastantes años de vida como peón y campesino junto con papá, en las zonas más enmontadas de la Península de Nicoya y el Volcán Miravalles. Antes que papá, migró con sus hijos para acomodarse al lado de la hermana mayor y su madre, jugándosela con la zapatería y cualquier oficio que él creía que podía desempeñar. Así, en la misma casa, que mi tía pagaba al INVU con su trabajo de costurera en una fábrica de mucha tradición y algunas extras en la casa, se improvisaron algunos estantes y se comenzaron a vender distintos artículos de bazar y pulpería, con poca inversión, porque no se tenía. La casa se hizo

\footnotetext{
${ }^{61}$ Expresión de las personas pobres usada décadas atrás, refiriéndose al empeño de obtener ingresos mediante cualquier forma de trabajo honesto.
} 
pequeña para albergar a quienes ahí llegamos, además de las empresitas familiares que se trataron de crear. Pero la solidaridad familiar era la que privaba en un ambiente y espacio muy limitado.

Mi tío puso su zapatería y disponía de los juegos de hormas, bancos, cuchillos, pinzas, alicates, martillos especiales, punzones y muchas otras herramientas propias de ese oficio. Su hijo mayor, quien asistía al segundo grado sería su principal ayudante. Junto con las suelas, tarros de tachuelas, cemento y betunes, se consiguió un banco y agregó a su rotulo de "Zapatería Elizondo" el de "barbería". Así algunos clientes le llegaron, principalmente de los carajillos de las casas cercanas, que eran bastantes y requerían corte de cierto estilo, para asistir "bien presentados" a la escuela ubicada a escasos cien metros de distancia, el "pelado" de "coco con copete" era muy usado en ese entonces.

La nuera de mi abuela, con cinco hijos huérfanos de padre, quien también había llegado de rumbos similares, "se la jugaba" lavando ropa ajena con la ayuda de mi abuela, dando el servicio a quien lo requiriera. Eran formas de "lograr el cinquito" y que los "chiquillos vayan a la escuela". El complemento era la venta de panes caseros como budines, quequitos, pan de leche, prestiños, cajetas y en ciertas épocas los tamales.

Parte de un agregado hecho sobre el patio, que era relativamente amplio, hubo de ser techado e improvisar otros espacios, que incluyeron varios cuartos adicionales, para dar abrigo a toda esa güilada. Además ahí hacíamos tareas escolares, escogíamos arroz y frijoles para el almuerzo y el gallo pinto de las mañanas, se amarraban tamales que luego se iban a vender a las alamedas cercanas en sendas ollas bien presentadas y cubiertas con mantelitos blancos. Cuando llovía debía tenderse ropa y en las noches se debía dormir.

En otros años y barrios, principalmente quienes vivían al sur del centro de San José, otros familiares de abuelita también habían puesto pulperías, verdulerías o bazares, luego de una tradicional vida en actividades agrícolas. Era una forma de sobrevivir en la misma casa, sin recurrir al trabajo asalariado. Pero mi abuela desde que migró de San Ramón a San José no regresó nunca a la vida en el campo, lo que tampoco ocurrió con papá, aunque si con el Tío Juan. 
Conseguir en alquiler una casa con pulpería fue un logro para papá con el apoyo de abuelita. No era tan grande como la de mi tía, ni tenía un patio amplio. Una señora ya anciana la había adquirido hacía poco tiempo de otra anciana. Doña Dora la había alquilado durante varios años, siendo su apoyo en la cría de sus también numerosos hijos, con su esposo ocupado en labores de construcción. Era casi toda de madera y tenía unos veinte años de construida. Una parte del piso era de mosaico: el espacio de la pulpería que seguro había sido la salita, el de la cocina y área de pilas y el baño. Era una combinación de verde con amarillo claros. Solo las paredes del baño eran de ladrillos. El resto, incluidos los pisos, el cielo raso y las cerchas, de madera.

La casa tenía dos entradas. Una era la principal, convertida en la puerta de la pulpería, que por estar en la esquina formaba ángulos de 135 grados con las paredes este y norte respectivamente, siendo un poco más ancha de lo normal, pero de dos partes que se juntaban para cerrarse en el centro. Papá apalancaba el cierre desde uno de los mostradores con una regla de dos por dos y como de dos metros y medio de largo. Además tenía picaportes en el piso y la viga superior.

Una parte de la casa fue construida con posterioridad al diseño original. La vivienda contigua era parte de la misma propiedad, pero en medio de ambas se hizo ese agregado, que consistía en dos habitaciones separadas por una pared de tablas, con piso de madera levantado sobre vigas colocadas al nivel del piso de la cocina, quedando una abertura entre el suelo y las tablas del piso. Hacia la calle una de esas habitaciones formó lo que sería una salita, con puerta de salida a la calle, ubicada luego del cuarto de Abuelita. La otra era una habitación abierta, con entrada por la cocina y sin pared con el área de pilas y una puerta que daba a un patiecito cementado, que si acaso tenía un metro de ancho por unos siete de largo. En una parte, de un lado este patio daba a las ventanas de uno de los cuartos y del baño de la casa contigua, la que era de la misma propiedad. Nuestra cocina no tenía ventanas y estaba en el centro de la casa. La que fue salida al patio, dio paso a la puerta de ese agregado. La luz natural le llegaba por el área de pilas, cuya pared con el patio era un enrejado de tablillas de una por una, cruzadas en forma de " $X$ ".

En la casa no habían zacate, plantas, ni nada parecido, lo que abuelita procuraba ir solventando con algunas macetas de "lotería", que era una de sus preferidas, además que no perdía la esperanza de un día "pegarle el gordo". 
El patiecito estaba separado por una pared de ladrillos de la casa que seguía al oeste, donde vivían la familia de doña Amalia, su esposo y sus hijos Macha y Macho. De un alto como de dos metros, se podía caminar por esa pared y ver el patio de nuestros vecinos. También se veían las cerchas de la parte del cielo raso del agregado que he descrito, pues el alero carecía de cielo raso y canoas.

La existencia de ese agregado, dio lugar para que abuelita pensara en la posibilidad de alquilar a otras personas y así tener un complemento para pagar el alquiler. La dueña no puso inconveniente, pues nos alquilaba en cincuenta y cinco colones y nuestros inquilinos pagarían veinte colones. Papá siempre sería el responsable de los pagos. Efectivamente la idea cuajó y llegaron a vivir una señora joven, con quien parecía ser su esposo y dos hijos pequeños. Pero el asunto fracasó, pues resultaron "mala paga"62. Luego de los malos ratos y pleitos, la experiencia hizo que durante bastante tiempo esos espacios no fueran muy utilizados y papá mantenía ahí alguna mercadería, un catre sin usar, una tijereta y otras cosas.

El espacio de la salita si fue útil para hacer los rezos a los que era muy devota mi abuela. El fallecimiento de un familiar, si era muy cercano, era acompañado de la organización de un novenario. Supongo que papá en acuerdo con mi abuela contrataban una rezadora. Con mi hermana arreglaban un altarcito y ponían unas tablas para rezar y se invitaba a familiares y al vecindario a acompañar los nueve días del rosario. Por supuesto que mi hermana y yo estábamos obligados a seguir, con absoluta devoción y en voz alta, cada una de las oraciones que la rezadora desarrollaba.

Tiempo después de la experiencia de los "mala paga", escuchaba que papá y abuelita hablaban de un congelador. Hicieron un contrato con un carpintero para que hiciera uno y me imaginaba algo parecido al que se usaba para los helados. Cuando lo vi, de madera, me pareció extraño que no era metálico ni tenía conexiones eléctricas. Tampoco estaba pintado y mantenía el color natural del ciprés. Era un cajón similar a un baúl grande de madera, en forma de cubo, como de unos ochenta centímetros de cada lado, sostenido por cuatro patas, pero forrado por dentro con láminas de hierro galvanizado y se abría con una tapa pegada con bisagras y una gran perilla para levantarla.

${ }^{62}$ Que no pagaban a tiempo sus obligaciones o del todo quedaban debiendo. 
La idea era que ahí se pudiera tener el hielo para poner una venta de granizados por la puerta del agregado que daba a la acera. Como esa era una zona que en la calle jugaban muchos güilas y pasaban los vecinos del barrio, era un punto donde se podría promocionar la venta del producto. Me asignaron hacerme cargo del negocio. Me explicaron el uso del raspador, aunque se compraron dos tipos, uno era redondo donde se colocaba un vasito de cartón en forma de cono, que al raspar se llenaba de hielo y se le daba vuelta para agregar el sirope y la leche condensada. El otro era en forma de trapecio, donde el hielo raspado queda prensado, se abre la tapa y se deposita en el recipiente donde se despacha el granizado. Ahí me instalé durante algún tiempo, principalmente en las tardes después de regresar de la escuela, con un rótulo rústico hecho sobre una tabla: "Hay granizados".

Mantener el negocio requería cierto trajín. Había que ir a comprar el hielo a la fábrica, que en ese tiempo quedaba contiguo al puente de la vía férrea sobre la calle que va entre la embajada de la República de México y el Hospital Calderón Guardia. Era de estilo galerón o bodega, con espacios separados o divisiones grandes y muy frías. Ahí despachaban el hielo en marquetas enteras, medias o cuartas. Cuando papá iba compraba media y si yo iba, traía una cuarta. Había que traerlo cubierto en aserrín dentro de un saco. Mientras tomaba el bus, al costado del Hospital y llegaba con la carga, algo se deshacía de camino. Luego acomodarlo dentro del saco y éste dentro del "congelador", para mantenerlo a cubierto mientras llegaba un cliente a comprar. Teníamos sirope de kola y de zarza. Los que más se vendían eran los de kola, pocos con leche condensada. No se vendían con la leche en polvo. Gran parte del hielo, casi todo, simplemente se deshacía y se iba por una manguerita que había como desagüe en el fondo del aparato.

Al principio el asunto pareció ir bien. Aparecieron algunas clientas cotidianas, de las partes de la calle asfaltada y casi nadie de la parte de la calle de tierra, que era donde había más güilas. Una era Nora y otra Maritza, una muchacha muy bonita y estudiosa que vivía en una casa aledaña a la ebanistería. Pero luego las ventas fueron disminuyendo al punto que no se hacía para recuperar lo que se invertía en el hielo y el costo de la traída.

Tiempo después el asunto de los granizados se "hizo agua". Tampoco resultó. Pero mi ubicación a cargo de "ese negocio" me dio tiempo para leerme varias veces los "Cuentos de mi Tía Panchita", que había adquirido en 
una pequeña librería ubicada cerca del consultorio del Doctor Gutiérrez, así como el libro de Cocorí, que alguien me prestó. Pero además una buena cantidad de episodios de las historietas de Batmán, Supermán, Tarzán, El Ilanero solitario, Chanoc, Memín, Los cuatro fantásticos, Turok, Alma Grande, el conejo Bugs, el pato Donald y algunas otras. Al cerrarse el asunto, debí encontrar una forma de esconder las revistas y los libros, no fuera que me los fueran a encontrar y desaparecer por "andar de vago", pues así pasaba cada vez que papá me encontraba alguna de las historietas que me regalara alguno de los primos cuando nos visitaban.

El espacio del cielo raso al que accedía desde el patio se convirtió en mi bodega de "lecturas prohibidas", que incluían las populares tiras cómicas, algunos de cuentos, un ejemplar del libro Historia de Costa Rica de Carlos Monge Alfaro, que alguien me había mercadeado junto con uno de fundamentos del idioma inglés.

La salita continuó funcionando como tal, con un juego de muebles y una mesa donde mi hermana hacía buena parte de sus tareas colegiales. También ocasionalmente era centro de encuentro de güilas amigas de mi hermana, que llegaban a jugar cromos, yacses, lotería y algunos de naipes como "ron" y "21", además de contar chiles y anécdotas del barrio.

\section{UN BARRIO SIN NOMBRE}

Marvin era compañero en quinto grado y hasta mediados de año vivió en una casa esquinera, en Santa Cecilia. Al salir de clases, a veces nos veníamos en grupo de unos seis a diez, pasando por las casas de algunos y cerca de las de otros. A mediados de año Marvin llegó al barrio, con su madre doña Carmen, y su padrastro don Carlos, donde alquilaron una de las casitas como a 50 metros de la casa esquinera de doña Carmen, nuestra vecina de enfrente. Así que ahora teníamos dos doña Carmen. La casita está justo después de una entrada, encerada y con jardín, que daba a una serie de cuartos y casas pequeñas que eran de don Gonzalo, quien las alquilaba a familias pequeñas o personas solas.

Desde su llegada se dio a conocer por su activismo en el barrio. Participaba en todos los juegos y se metía en cuanta aventura se presentara. Me es dos 
años mayor y con una bicicleta de carreras era "rajón" y "conversón"63. Siempre tenía un papel de organizador y arrastraba a los demás a incursiones por los lotes y fincas vecinas. A veces salía en la bicicleta, llevaba su botella de agua y pasaba un rato a la pulpería. A las horas llegaba contando a papá que había llegado hasta Alajuela, o que se había ido a Rancho Redondo o a Cartago. Un día se iba a ir más largo, como Turrialba o San Ramón.

En una de esas comenzó a preguntar por el nombre del barrio, ya que si tenía que decir donde vivía, pues tenía que saber. Nadie le supo decir. Alguno le decía que Paso Hondo, pero rebatía que eso era abajo, por la curtiembre. No era La Maravilla, que era el barrio y nombre de una panadería ubicada a doscientos metros al este del Cine Reina y eso era más arriba. Otros que Santa Eduviges. "¿Nombre, eso es allá atrás y dando toda esa vuelta, aquí ya no es ese barrio, además es otra gente. Este barrio tiene que tener un nombre, ¿Cuál es?"

No se estuvo conforme. Así que haciendo mofa del olor de la curtiembre, llegó a la conclusión: "Bueno como allá abajo tenemos ese aroma tan encantador, el nombre de este barrio tiene que ser viento fresco... De viaje se siente el cambio cuando uno sube hasta aquí". Así que en cada oportunidad que tenía de llamar por un nombre al barrio, le decía "Viento Fresco" y más de uno se le quedaba viendo, como interrogando si aquel sería un nombre apropiado o si debía dársele un nombre.

En todo caso las direcciones siempre se daban en función del cine y si se tratara de quienes vivían a orillas del río, su dirección era 500 metros al sur del cine Reina.

A diferencia, doña Carmen y don Carlos eran personas bastante serias. Marvin tenía un hermano mayor, a quien poco se le veía en las barras de los grandes, pues tenía su trabajo y salía desde muy temprano hasta casi la noche. No era de salir con frecuencia a las juntas que se formaban en las noches en la esquina y pocas veces lo hacía en las tardes de los sábados o los domingos.

Doña Carmen y don Carlos se hicieron nuestros amigos, incluso confidentes. Ella blanca y alta. Don Carlos era moreno y un poco bajito, tenía la sastrería como oficio y rápidamente se hizo de una clientela en el barrio, además de personas que ya lo conocían y llegaban a hacerle encargos. En el rincón de la

${ }^{63}$ Rajón: que alardea de sus habilidades y logros. Conversón, por conversador y sociable. 
pulpería pasaba horas conversando con papá, relatándole las virtudes y capacidades de trabajo de don León Cortés, de don Cleto y don Ricardo, a quienes consideraba como los grandes hombres de la historia de Costa Rica, aunque no tanto como el Doctor Calderón Guardia. Las reformas sociales eran parte de sus recuerdos, así como su participación en la guerra civil.

Como a otros carajillos, de vez en cuando Marvin andaba con una flecha. ${ }^{64} \mathrm{En}$ puntería competía con Kiko, el hermanito de Nora, a quien nadie le ganaba, pues si quería traerse un pajarito, encontraba el punto desde el cual "hacerle el tiro" y no fallaba. Como las fincas eran cafetales, abundaban los arcos de donde confeccionar buenas flechas y solo tenían que conseguirse un par de ligas de las que usaban las señoras para sostenerse las medias de "nailon", o las compraban en la pulpería.

Pero Marvin además tenía sus "jabas" 65 y le gustaba tener de ciertas especies y escucharles cantar. Supongo que en algún momento vendía o intercambiaba sus presas. Utilizaba una jaula que era más pequeña y tenía un compartimento especial para poner una trampa. En sus andanzas se percataba de alguna posible presa y donde podía ser el punto para colocarla. Seleccionaba un árbol, colocaba un pedazo de fruta o algo que atrajera al pajarito, que al llegar a comer caía la tapa y quedaba atrapado. Entonces salía del escondite de donde vigilaba y recogía la presa. Luego pasaba por el barrio luciendo al pajarito y se dedicaba a cuidarlo para lograr que cantara en la jaula.

También le gustaba agarrar pericos de los árboles. En una oportunidad apareció un periquito en el árbol de guaba de la casa de doña Carmen, frente a nosotros. Se subió poco a poco y lo atrapó. Luego bajó con el animalito y la mano ensangrentada por los piquetazos. Se lo llevó a cuidar y le puso su jaulita. A veces se iba al mercado central o El Alto66 y ahí hacía sus intercambios o ventas. La afición algo le dejaba.

\footnotetext{
${ }^{64}$ Flecha: es una especie de arma similar a una honda, que se confecciona con una horquilla de madera, preferiblemente de la bifurcación en dos ramas de un arbusto de café, utilizando la forma pronunciada del arco para amarrar dos ligas o tiras de hule, que se juntan con un cuerito de forma cuadrada, donde se coloca una piedra o algo similar, que al estirar los hules o ligas y soltar, impulsan la piedra como un proyectil en la dirección deseada.

65 Jaba: Una forma de jaula para atrapar aves pequeñas.

66 "El Alto": es un barrio situado al este del centro de Guadalupe, después de "La Robert". Por su ubicación era el punto de llegada de la ruta principal de autobuses de Guadalupe a San José.
}

ISSN: 1659-0066 


\section{COMIÉNDOSE LA GANANCIA}

Desde el negocito que se tenía en la casa de Ipis y en la de Villa Ligia, abuelita y la tía Angelita me hicieron acuñar una frase: no había que comerse la ganancia. Si se tenía un negocio, no se podían consumir los productos en perjuicio de la utilidad, que era lo que daba razón a la actividad y permitía que se pudiera mantener. Así que desde más niños hacíamos esa diferencia y solo con permiso se podía tomar una fanta, o comerse un chocolate, helado u otra golosina. Lo mismo se hacía con los productos de consumo familiar como los comestibles y jabones. Papá llevaba un cuaderno donde anotaba todo lo que se tomaba para el consumo y hacía sus cuentas, creo que mensualmente.

La pulpería tenía una entrada esquinera. No tenía mucho espacio para los clientes. La "caja", ubicada en la estantería hacia el sur del local y frente a la llegada de lo clientes, era un cajoncito y una gaveta con unos compartimentos para separar las monedas según denominaciones y los billetes. Había que dar la espalda a los clientes para guardar los pagos o dar los vueltos. Por encima y colgando de los estantes por unos clavos, estaban los exhibidores de cigarros: uno de cada empresa: la "tabacalera" y la "republic tobaco", que periódicamente cambiaban la publicidad y de vez en cuando sacaban marcas nuevas.

Abajo unos cajones de madera, casi empotrados entre el estante y la pared, con arroz, frijoles rojos y negros. Había uno con garbanzos, que casi nunca se vendían. El azúcar se mantenía a un lado en el piso, en los sacos originales de un quintal, que eran parecidos a los de harina: de varias láminas de un papel grueso. Papá pesaba libras de azúcar en bolsas de papel, que doblaba al estilo de los pulperos, dando una forma particular al empaque, que era el mismo utilizado para el arroz y los frijoles. Así no había que estar pesando cuando la clientela y el tiempo apremiaban. Al principio se tenía una balanza, pero creo que a papá no le gustaba y al poco tiempo se consiguió una romana que colgaba de un gancho y marcaba las libras y las onzas, que era lo que interesaba.

Se tenían dos mostradores, que estaban juntos casi al mismo nivel. En uno se mantenían todas las confiterías y golosinas dulces: guayabitas, nacionales, tapitas, corazones, milanes, tricopilias, caramelos de coco y de leche, 
guaritos, morenitos, frutinis, mentas y violetas. Casi todos de la misma marca. ${ }^{67}$ Un señor pasaba cada martes con un camioncito cerrado y los gallitos pintados cruzados por el letrero. Leía la lista que estaba contenida en los factureros y papá le indicaba de cuáles dejara una o dos bolsas para surtir de confitería. La tapa de este mostrador era de un vidrio grueso. Encima había unos frascos con los confites de venta al menudeo como los de mantequilla, de menta, paletas, "alborotos" y otras variedades.

En el otro mostrador, se colocaban los panes: el que diariamente traía el panadero y se vendía en pocas horas y otros panes dulces, que eran pocos. También la repostería o "tosteles": gatos, cuñas, queque negro y borrachos eran los más vendidos, que se abastecían de un señor que vendía en una bicicleta. Pero el panadero, que pasaba a cobrar en el transcurso de la mañana, era quien abastecía la mayor parte de repostería. Se tenía un proveedor de un carrito, que también tenía ciertas galletas, como las dulces, biscotelas, polacas, cocadas, las avión y acemitas. Recuerdo que las "avión" se vendían a cuatro por cinco y a veces se utilizaban para dar ferias. Las galletas dulces se tenían en un frasco particular, ubicado a la par del azúcar y los granos pesados en libras.

A un lado, de manera perpendicular, un congelador formando una escuadra, donde habían helados y de vez en cuando hielo. Lucían las chocoletas, que venían en unas cajas de cartón, cremoletas y "cajitas de helados" de las pequeñas, en sabores de crema, fresa y ron con pasas. Solo de vez en cuando se tenían cajitas de mayor tamaño, porque se vendían muy poco. Para efectos de nuestra entrada y salida, una portezuela cerraba entre el mostrador y el congelador.

Cuando papá "me dejaba a cargo" y abuelita se quedaba tejiendo en su cuarto, a veces mi hermana se quedaba también en la pulpería. Entonces nos entreteníamos conversando con algunos de los carajillos del barrio, Ernesto, don Carlos, Nora o don Enrique. Pero generalmente escuchaba "Chucho el Roto", "Felipe Reyes" y "Arandú"68 en el radio. Me sentaba en el banco junto a la ventana, abría la portezuela del mostrador de confitería y por los vidrios miraba hacia la esquina del cine Reina.

\footnotetext{
67 Dada por la fábrica "Gallito", que por cierto quedaba en Guadalupe, contiguo a la planta de los liceos Napoleón Quesada y José Joaquín Jiménez Núñez, donde por unos años existió una de las extintas rotondas de la carretera de circunvalación. Lástima que luego de su venta a una transnacional las confituras no tienen el mismo sabor.

${ }^{68}$ Esas eran novelas radiales. Se transmitieron por varios años.
} 
Abajo contemplaba los chocolates y otros confites, que se mantenían en unas cajitas metálicas cuadradas como de $15 \mathrm{~cm}$ de lado y una pulgada de alto, que eran cortesía de la "Gallito", para la exhibición de sus productos, pintadas de color crema y con el logo de los gallitos a los lados. No me gustaban mucho las tricopilias, ni los nacionales. Pero los guaritos y las tapitas, con los caramelos de coco eran de mis preferidos. De vez en cuando alguno de los confites de mantequilla o de menta, que eran blancos con unas rayas rojas. Estos también eran los que más le gustaban a mi hermana, quien de vez en cuando agarraba una coca y le vaciaba un tarrito de leche condensada, lo que aprendió de Nora, quien a veces llegaba y compraba las dos cosas y las mezclaba, mientras se quedaba su buen rato en la pulpería.

\section{ABASTECIENDO DESDE EL MERCADO Y LOS ALMACENES CERCANOS}

En esos años los buses llegaban hasta los alrededores del Mercado Borbón. Los de Moravia y Guadalupe, daban la vuelta por el cine Líbano y terminaban su carrera estacionándose en lugares especificados para cada uno en la avenida quinta, al sur de aquel mercado. Anteriormente algunas de esas rutas aún bajaban desde el Hospital Calderón Guardia y el Parque Nacional, por el Paseo de Los Damas, hasta el frente del Almacén La Granja y de Barguil. ${ }^{69}$ Tiempo después esas paradas las pasaron frente el Telar Los Leones, después las fueron acercando a la kodak, para finalmente dejarlas como ahora, que ni a la Fischell llegan. Pero en esos años eran más cómodas para los mandados que teníamos que hacer, porque nos dejaban justo donde había que realizar gran parte de las compras.

Papá iba dos veces por semana al mercado y sus alrededores a comprar algunos abarrotes y verduras. Luego empezó a llevarme y a enseñarme cómo y a quién comprar. La entrada al Borbón, ${ }^{70}$ al frente de la puerta principal de La Granja, era el punto en donde se podían comprar las papas y a veces zanahorias y cebollas. Se compraban dos o tres cuartillos de papas. Bajando por esa entrada, que es una cuesta, casi a la mitad hay una entradita a la izquierda, por donde bajando una grada angosta se llegaba a una bodega donde nos vendían bananos. Compraba dos o tres manos. A veces se

\footnotetext{
${ }^{69}$ La Granja era un almacén donde se expendían herramientas y otras utilidades agrícolas. Barguil es un almacén de artículos de talabartería.

70 Nombre de uno de los mercados, tiene tres niveles y ocupa poco menos de una manzana de terreno.
} 
compraba tomate en cajas, en unos tramos situados al centro del mercado en el segundo piso, donde también se conseguía manzanilla, naranjas y limones.

Cruzando, por la calle ocho en la esquina, se compraba el queso tierno, un pedazo como de dos o tres libras. En la esquina siguiente, en un almacén de abarrotes, se compraban algunos enlatados y jabones de baño. Bajando de esa esquina hacia el oeste, estaban los almacenes donde se compraban los granos y otros abarrotes. Entre ellos estaba el de Guillermo Constenla y el de Marcial Salas. Casi todas estas compras se hacían donde Salas. Llegué a hacer amistad con los dependientes y el administrador, que siempre me trataban muy bien. Eran un almacén familiar, ya que eran el señor Salas y creo que dos o tres hijos. También tenían dos o tres empleados.

Casi siempre se compraba una arroba de arroz y a veces una de frijoles, generalmente negros. A papá y la generalidad de los clientes no les gustaban los rojos. Usábamos unos sacos de gangoche, suaves para cargar y entre dos sacos se hacía una forma de alforja, que se cargaba en los hombros de lado a lado. Si se tenía más carga, una caja de tomates se colocaba encima y aún se podía cargar una bolsa de la otra mano. En los alrededores del cine Adela había unos negocios donde se compraba el queso Bagaces, ${ }^{71}$ que casi siempre lo vendíamos como queso en polvo.

Siempre había que comprar un rollo de puros, que los vendían en varios tramos del Mercado Central. ${ }^{72}$ Se buscaban de ciertos puros que eran del gusto de los clientes, los más baratos, nada de esos "de marca" o en cajitas. También ahí se conseguían tamugas de dulce, que luego se vendían en tapas o atados, que solo en dos de los tramos se compraban: papá se fijaba mucho en el tono del color oscuro y el precio. Los propietarios de esos tramos tenían cierto carácter que me provocaba algún susto y solo uno de ellos era amable. Este mismo señor sabía cuál era el dulce que nosotros comprábamos. Además papá siempre tomaba aguadulce en la madrugada, la tarde y a veces en la noche. Así que él era el catador principal de la calidad del dulce, que debía ser a su gusto. También se compraba alguno menos oscuro o pálido, pues había ciertos clientes que les gustaba de esa manera.

\footnotetext{
71 Debe el nombre al lugar donde durante la colonia se hacían quesos duros de buena calidad, entonces villa de Bagaces, hoy un cantón de la provincia de Guanacaste.

72 Este es el mercado principal de la ciudad de San José, data de fines del siglo XIX y ocupa una cuadra completa.
}

ISSN: 1659-0066 
De regreso en el bus colocábamos los sacos y las cajas en un espacio que se formaba a la par de la puerta delantera. No era mucho lo que comprábamos y papá nunca contrató un carrito de carga, pues eso implicaba un gran gasto adicional. Procurábamos sentarnos en los primeros asientos para ir vigilando la mercadería. Si se había algo delicado se llevaba en brazos. Solo tomábamos los buses de El Alto o Moravia, eran los que paraban más cerca del mercado y luego, eran los que cobraban 20 céntimos y cuando la tarifa subió, 25 céntimos, además de tener mayor frecuencia en el servicio.

\section{MASCANDO TABACO}

Los puros tenían pocos clientes, pero básicamente se le vendían a don Alfredo, un anciano octogenario, casi ciego, que usaba unos anteojos con vidrios un tanto verdes y gruesos. Vivía con su esposa, doña Amelia, dos hijos ya mayores: Jorge y Rigo y una nuera que poco salía, en una casa que lucía ser antigua, con piso de tierra y paredes de tablas al natural, que en el techo tenía partes de zinc y otras de tejas. Alrededor guindaban macetas entre las rendijas que se hacían entre las tablas de las paredes. Se ubicada casi a la entrada de la primera finca de café hacia el sur de la pulpería, junto a un camino que al final de las casas de la acera de la pulpería por la calle de tierra, cerraba la isla que se formaba con la calle de piedras al juntarse rumbo a la curtiembre.

Como ciertas casas de campo, tenía horcones cuadrados y algunos con la forma original de los troncos, pero descascarados. Las reglas que unían los horcones, servían de cimbras para diversos objetos de adorno o religiosos. Tenían camas de tablas y solo un catre donde creo que dormía Rigo. Entre dos de los horcones que cerraban un corredor de tierra del frente de la casa, una hamaca, con tejido de mecates, servía para el descanso de Jorge y a veces de Rigo, más que nada en las tardes de los sábados, o el transcurso de los domingos luego del regreso de misa.

Ellos tenían cuaderno para llevar fiado y no usaban libreta. Confiaban en las anotaciones que papá hacía. Las compras las hacían doña Amelia y Jorge, a quién papá distinguía como "Jorge el gato", por el color de sus ojos. Doña Amelia a veces se apersonaba a comprar una tapa de dulce, una piña de pan o algunas galletas, un pedacito de queso o un par de huevos. A veces 
también se llevaba un paquete de cigarrillos "dominó" o "león". ${ }^{73}$ De vez en cuando una sopa o unos cubitos maggi. ${ }^{74}$ Tenía la distinción de que portaba vestido de franciscana, pues seguramente alguna promesa o devoción inspiraba su caminar a paso lento pero firme.

En las tardes, "Jorge el gato" regresaba un tanto sudoroso y con una alforja en los hombros, donde seguramente había llevado su almuerzo a alguna finca en donde prestaba sus servicios. Colgando de una fajita de cuero, amarrada a un cinto de un mecate doble, lucía una lima y, amarrado, un machete con su garabato, ${ }^{75}$ que seguro estimaba mucho. Después de todo un buen garabato siempre es bien apreciado por un peón hábil y digno de su manejo. A veces colgaba también una bolsita plástica, donde traería alguna confitura o comida especial para la casa. Pasaba a llevarse dos o tres "deltas" (otra marca de cigarrillos), una onza de café "dorado", ${ }^{76}$ a veces pan o galletas dulces, tal vez un jugo del campo, ${ }^{77}$ algún salchichón o chorizo. Después de conversar unos minutos ... "me lo apunta don Uriel", "claro que sí don Jorge", daba las gracias y tomaba las cositas, se acomodaba la alforja y recogía el machete y el garabato, que siempre colocaba detrás de la puerta mientras permanecía en la pulpería, y de vuelta a su casa. Los sábados en la tarde puntualmente pagaba la cuenta.

Don Alfredo pasaba casi todos los días como a las ocho y media de la mañana. A paso lento, propio de sus años, iba a realizar mandados por el centro de Guadalupe. Alrededor de las once venía de regreso con su bolsa de mecate, con algunas compras hechas en "El Bodegón" y a veces con una bolsa de carbón, de las que vendía "don Quiko" en una casa un poco vieja, que estaba donde ahora hay una venta de pollo frito, media cuadra al oeste

\footnotetext{
73 Estas eran marcas de cigarrillos sin filtro, más cortos que los corrientes y del menor precio.

${ }^{74}$ Forma de un concentrado sólido, como de un centímetro cúbico, para hacer caldo con sabor a sopa de pollo.

75 Garabato: es una herramienta que utiliza el peón en el campo o los montes, para acomodar la hierba para protegerse y cortarla mejor. Generalmente se elabora de una rama delgada, con solo el grosor necesario para tomarlo firmemente con la mano, hecho de un arbusto de madera fibrosa y resistente. Del largo similar al cuchillo, se debe cortar en la parte donde nace otra rama pero que tenga ángulo recto. De la ramita que nace, del mismo grueso o un poco más delgada que la parte larga, se corta del largo de una cuarta de la mano, formando una especie de gancho o "media $T^{\prime}$, que es la que se utiliza para acomodar la hierba.

76 "Delta": una marca de cigarrillos con filtro, que en esa época era la más popular y de menor precio. "Dorado" es una marca de café, también de gran consumo popular en esos años, pues de otras marcas casi nadie compraba, aunque se tenían a la venta.

77 "Del campo": era una marca de jugos de frutas enlatados. Eran de pera, melocotón y albaricoque. Luego los variaron y mezclaron, pero no sobrevivió a la competencia de una transnacional frutera.
} 
de la esquina suroeste del parque. Siempre pasaba a la pulpería, aunque no lo hacía cuando iba de salida.

Venía mascando tabaco, de los puros que nos compraba. No los fumaba. Generalmente se quedaba ratos conversando con papá. Contaba historias de cuando Guadalupe era un cafetal y para ese momento lo consideraba muy poblado. Decía que era una calle y todo a los lados eran cafetales.

Además de conversar y entretenerse un rato, compraba a veces cinco y otras diez puros, que tomaba con sus manos haciéndolos un rollito que guardaba en una de las bolsas interiores de su saco, y tal vez algún jabón o navajilla, café, pan u otros abarrotes, pero pagaba lo que llevaba. Nunca de fiado. Todo lo que compraba lo iba acomodando en su bolsa de mandados, que mantenía sosteniendo con sus antebrazos. Si era época de lluvias también andaba con paraguas. Siempre "mascando cuecha", ${ }^{78}$ con voz grave y pausada, don Alfredo contaba muchas anécdotas de sus andadas en fincas de lugares lejanos. Papá le hacía relatos de las fincas en Bagaces, Arío, Zapote y Upala.

De pronto don Alfredo, luego de mascar y mascar y entre la conversona, sin interrumpir su relato, se animaba y desde el mostrador se volvía hacia la puerta, hacía un leve gesto y como tomando impulso, lanzaba "un cuechazo". El escupitajo siempre quedaba en el centro del piso, que unas horas antes me había esmerado en dejar "reluciente". Siempre supuse que, a las cuentas que él hacía, la "cuecha de tabaco" había ido a dar hasta el caño de la calle de tierra. Pero el peso de las muchas décadas que colgaba en sus hombros, no lo dejaban hacer semejante lanzamiento, aunque por su limitación visual no se daba cuenta. El rato pasaba y entre otras marcas que iban dejando los clientes, las señas del tabaco iban desapareciendo. Habiendo mas o menos calculado el tiempo transcurrido y el que debía llegar a la casa, aunque a veces preguntaba la hora, con mucha cortesía se despedía y seguía rumbo a su casa, sin haber soltado ninguna de las cosas que cargaba de sus mandados mientras había transcurrido toda la conversona.

78 "Mascar cuecha": expresión de que mascaba tabaco. 


\section{"ARAÑÓLOGO" AFICIONADO}

Una vez que papá me había instruido y dado a conocer los lugares de compra, yo era el encargado de hacer los mandados para surtir la pulpería de las mercancías que no distribuían los agentes. También los que eran de la casa o para atender algún encargo de abuelita o de papá. Debía ir a la carnicería o a la verdulería, cuando se quería comprar algo para hacer una sopa los domingos. Para traer algún abarrote de unos negocios que habían por el parque de Guadalupe o carbón de donde Quico. Había una carnicería frente al Cruce a Moravia, donde un señor de estilo bonachón despachaba distintos cortes de res y cerdo. Si había que comprar pollo, tenía que ir por el "mas por menos", cerca de la "Noche Buena". Abuelita le gustaba comprar el pollo entero y cuando se hacía siempre era una ocasión especial, aunque yo no sabía cuál era la ocasión. Sería para enriquecer el menú cotidiano, aunque la sopa de pollo o de olla de carne, era de solo un día, de vez en cuando.

A veces también tenía que ir a la "Noche Buena", negocio donde se encontraba de todo lo que se pudiera imaginar, pues siendo como de estilo bazar, su propietario, dependiente y administrador, se las ingeniaba para mantener el surtido de las cosas más variadas en el más completo desorden, pero todo lo encontraba, ... después de un rato de buscarlas.

Otras veces tenía que ir hacia la tenería y las fincas de café aledañas. Fuera por algún encargo o para llevar o traer un mensaje, o para hacer el cobro de alguna venta de abuelita. En ocasiones era para conseguir hojas de plátano para hacer tamales o buscar alguna leña.

Haciendo esos mandados, en ocasiones me distraía metiéndome a los lotes desocupados, pero un tanto abandonados, o los mismos cafetales. Uno estaba ubicado entre la clínica del seguro Ricardo Jiménez Núñez, el barrio Santa Cecilia y el barrio San Gerardo, en el espacio donde hoy se ubica el centro comercial novacentro. Me metía por las cercas o uno de los portones ubicados sobre la carretera a Moravia, cruzaba entre los callejones del cafetal, saliendo hacia San Gerardo o a una calle que daba hacia Santa Cecilia, cerca de donde estaba la panadería donde también hacían galletas y parte de la repostería que llegaba a vender uno de los repartidores en bicicleta a la pulpería. 
De alguna manera me llamaban la atención las arañas, las telas tejidas simétricamente por algunas de colores llamativos y brillantes, que combinaban el amarillo, negro, rojo y verde. Aparecían en algunas de las cercas o arbustos de las orillas de los predios. También la amplia variedad en sus formas, colores, formas de cazar y lugares donde construyen sus sitios para vivir. Fui distinguiendo aquellas de otras que aparecían en las esquinas de las paredes o en rincones en el patio de la casa, aunque no era usual verlas, porque papá tenía la costumbre de estar rociando insecticida cada cierto tiempo, tanto en la pulpería como en toda la casa. Otras negras que construyen sus nidos entre las rendijas de las paredes, o huecos de piedras o ladrillos al final de sus telas en forma de túneles, con las que atrapan sus presas. Sin perder el miedo, con alguna varillita tocaba sus telas para observar como se escondían o se aprestaban a moverse cual si se tratara de alguna presa.

Un día, luego de observar como una araña de un color entre rojizo y anaranjado, atrapaba con su red un zancudo y luego lo envolvía con sus patas, la acorralé con un frasquito de vidrio, de los que por ahí iban quedando. Al rato observaba como el animalito tejía ahí mismo la trampa para obtener su alimento. Puse el frasquito en alguno de los estantes, un tanto escondido, por aquello de las dudas. Pero después procuré que tuviera su alimento. Así que me daba a la tarea de ir con el frasquito y su habitante por distintas partes de la casa en la búsqueda de alguna fuente nutritiva para tal mascota.

El asunto me desarrolló interés y con la realización de mandados, a veces tomaba un frasco si sabía que pasaría por un lote donde había visto algún espécimen que me interesaba. Primero fueron esas de jardín, que al quedar atrapadas les agarraba una brincadera que me hacía cerrar el frasco con prontitud, no fuera que se fuera a escapar o brincarme encima y morderme. Además me asustaba que se me subieran a las manos o al cuerpo, así que no las tocaba, sino que utilizaba ciertas varillitas. Con estas noté que no podían hacer sus hermosas telarañas dentro de los frascos, aunque fueran grandes, así que luego de un tiempo las ponía en cajas de cartón o las soltaba porque era difícil que atraparan las presas de alimento. Las "caseras" que aparecían en los rincones, si hacían sus telas en apariencia desordenadas y ahí atrapaban lo que les daba por almuerzo. 
Como sabía que se alimentaban de moscas y otros insectos, de vez en cuando tomaba un frasquito, lo destapaba y ahuyentaba la araña hacia el fondo y me acercaba donde había algún insecto y sigilosamente le ponía el frasco encima y luego lo cerraba cuidadosamente. Los más usuales eran las moscas, zancudos, abejas y ciertas cucarachillas pequeñas que eran una plaga. Si me costaba encontrar fuentes de alimento, me llevaba el frasquito al hacer un mandado y entre los predios encontraba algo crujiente y nutritivo que proveerles. Una vez atrapadas y envueltas las presas, permanecían un tiempo colgando del sitio donde la habitante la colocaba, pero a los días aparecía el cascarón o exoesqueleto en el fondo del frasco, por lo que con el tiempo se hacía cierta suciedad y procedía a cambiar el frasco. Nunca se me ocurrió una forma de abastecerlas de agua, pero al parecer no les hacía falta.

También notaba que a veces, luego de varios días o semanas aparecían unas bolitas cafecillas o amarillentas, como del tamaño de la misma pancilla de la araña, que luego me percaté eran los huevecitos, pues efectivamente, algunas semanas después brotaban la gran cantidad de crías y se me hacía un desbarajuste de qué hacer con tan prolífica descendencia.

Otras que atrapaba eran unas de patas largas de color gris o casi negras, en los alrededores de una quebrada que bajaba hacia el río detrás de la tenería. Buscando entre las piedras y troncos, pues así había leído en algún libro, encontré algunas de color café y peludas, grandes en comparación a las que se podía atrapar en la casa o el patio, pero similares en tamaño a algunas de las amarillas con negro o verde y rojo de los lotes. Estas tenían unos colmillos que al verlos me recordaban alguna de tamaño desproporcionado, vistas en ciertas películas de miedo que a veces pasaban por televisión. Al estar encerradas en el frasco podía observarlos con la seguridad de que no me iban a morder.

Las peludas de color café algunas personas las llamaban "picacaballo" o tarántulas, las encontraba también en el cafetal por el que salía a San Gerardo y en un lote que había antes del negocio de la Sodita Guadalupe.

Casi todas estas peludas y grandes no hacían telarañas. Cazaban atrapando las presas con sus patas delanteras y enseguida les hundían los colmillos, para luego irlas devorando poco a poco. Al final formaban una bolita con los desechos no comestibles, que expulsaban del sitio donde permanecían sigilosas a la espera de otra presa. A estas les ayudaba a construir sus nidos 
agregando alguna ramita con una hoja seca al frasco, lo que en ocasiones también hacía con las que construían telarañas.

Paulatinamente la cantidad de especímenes se fue ampliando y diversificando. Tenía varios frascos con los animalitos, que por seguridad los iba colocando debajo de mi cama en una caja grande de cartón. Fui aprendiendo que no las podía poner juntas, porque alguna de ellas desaparecía o las dos se morían. Las fui acomodando en grupos y mi hermana me regañaba por tener esos bichos "tan feos y asquerosos". Había quienes entre los del barrio les daba asco o desagrado, a otros curiosidad. Para mi era asunto normal: la araña se comía ciertos bichillos para alimentarse. De vez en cuando limpiaba algún frasco, o mudaba su habitante a una residencia más cómoda y limpia.

También supe que ciertas cucarachas eran nocivas, pues procuraba atrapar alguna para los especímenes grandes, pero luego de ingerirlas noté que morían uno o dos días después, lo que provocaba mi decepción por haberlas cuidado o por haberlas sacado de su antiguo lugar de vivienda. Aunque no asocié de inmediato la causa de muerte a ciertos blatodeos, paulatinamente, sin saber cuál era la verdadera causa evitaba este tipo de presas.

En cierta ocasión, mientras hacía los mandados por el mercado, debía llevar unas manos de bananos. Así que pasé por el negocio que funcionaba contiguo a la rampa del mercado Borbón, que para mi era la entrada principal. A mano izquierda bajando esa rampa, estaba la entrada al negocio donde había una enorme cantidad de racimos apilados. Ahí escogía lo que iba a llevar. Había hecho amistad con quienes ahí aparentemente laboraban, jóvenes un poco mayores, pero con quienes pasaba un rato contando anécdotas, haciendo bromas o jugando "jupas" con una bola de tenis, o me entretenía haciendo suertes con un bolero que tenía el dueño.

Ocurrió que al mover uno de los racimos, en una parte del techo de la bodega que era baja y había que agacharse, uno de los muchachos se quedó un tanto asustado y otro tanto curioso. Había una araña grande, que según su decir era venenosa. Me acerqué con la curiosidad de que podía ser una araña interesante. Estaba quieta, pegada al techo. Unos decían que era una tarántula, otros que una picacaballo, otros que "itenga cuidado porque lo puede orinar!", o "¡le va a brincar a la cara!" Los curiosos, entre quienes 
estaban el dueño y su hijo se apartaron un tanto, mientras decidían que hacer con el bicho.

Les dije que si me conseguían un frasco yo me la quería llevar. Nadie opuso otra opinión y alguien corrió a buscar lo que pedía. Lo trajeron y con cuidado le acerqué el frasco en una mano y la tapa en la otra, la cubrí y no se movió, mientras arrimé la tapa, corrí un poco el frasco para hacerla moverse, cayó al fondo y de inmediato puse la tapa, mientras daba saltos amenazantes o se movía levantando las patas delanteras y mostrando sus colmillos. Efectivamente era grande, como de cuatro centímetros el cuerpo y más de diez con las patas abiertas, de cierto color verdoso parecido al musgo y poco peluda. Ese día salí con premio.

Recordé que en uno de los libros del ICECU, había leído algo sobre alguna araña que se da en los bananales. Asociando el ejemplar encontrado entre los racimos de banano del mercado, deduje que podía ser de esas. Así que me fui a buscar el libro. Y efectivamente, terminé convencido que había atrapado a una "phoneutria" y así la denominaba y les indicaba a los carajillos del barrio cuando se las mostraba. "Es tan venenosa como una terciopelo", les decía. Me miraban con cierto susto, curiosidad o escepticismo. Me cuidaba de darle sus almuerzos y veía como atrapaba las presas con sus patas delanteras, las llevaba a sus colmillos y paulatinamente las hacía desaparecer. Luego aparecía una bolita con los restos no comidos.

\section{UN SECRETO EN EL CIELORRASO}

En la finca de Guacalito, a papá nunca le faltaba el chirrite. Siempre tenía alguna botella entre los montones de elotes secos, listos para desgranar, entre los sacos de frijoles cosechados o al pie de alguna raíz de un árbol cercano. El "resguardo" no faltaba y cuando el asunto se ponía peligroso, entonces utilizaba las cuevas de cangrejos, que ya tenía preparadas en la quebrada cercana de la casa, donde además mantenía siempre una reserva.

En la pulpería solo podía disponer de alguna botella de ron colorado de la cantina de Pascual. Pero al poco tiempo apareció don Bartolo. Era un señor bajito y delgado, con cierta fisonomía de panteonero de película, que siempre andaba con un saquito de gangoche y una alforja de tela grisácea un poco gruesa, en las que llevaba las botellas que distribuía a ciertos clientes. 
De vez en cuando, a papá le llevaba una botella o litro de "cabeza", 79 que probaba y gustosamente daba el veredicto positivo, dejándose el litro o a veces el galón. Con cierta regularidad, aunque no diariamente, papá degustaba medio vaso de casco, de previo al almuerzo, que siempre era al mediodía.

A mi me encargaba cerrar la boca y, con ayuda de una escalerita, subir al cielo raso por una portezuela, que quedaba sobre la puerta del cuarto de abuelita. Ya arriba, papá me pasaba la botella o galón y con cuidado me movía entre las cerchas, ${ }^{80}$ para colocarlo en un rincón hacia la parte de la cocina con el baño, donde la dejaba. Desde la portezuela, papá se asomaba para asegurarse que lo hubiera colocado de manera que no pudiera verse. Cuando me lo mandaba tenía que subirme y bajar el recipiente, con todo cuidado, parándome solo en las cerchas.

El cielo raso era de tablilla, muy tupido y bien pegado y estaba cubierto por una gruesa capa de un material que en ese tiempo creí que era el polvo acumulado, ya que salía todo tiznado en las rodillas y un poco en los hombros, pues más tenía que cuidar mi cabeza de los clavos del zinc del techo, así como de no dejar caer el preciado líquido y jalarme una torta. ${ }^{81}$ Con el tiempo supe que el cielo raso mantenía, desde hacía ya casi una década, las arenas del volcán Irazú, ${ }^{82}$ pues nunca había sido sacudido. Pero a la vez, ese arenero ayudaba a encubrir las botellas de chirrite.

En Semana Santa era cuando, junto con sardinas madrigal ${ }^{83}$ y encurtidos en moztaza, papá gustaba más de bajarse dos o tres medios vasos, que tomaba de un solo trago. Un poco menos para la navidad.

Abuelita también se hacía unos buenos rompopes, que nosotros si tomábamos, aunque a veces me tocaba una copita de chirrite puro y en seco, que me quemaba la boca y la garganta. El sabor se parecía al que papá alguna vez preparó de manera natural, sin ciertos ingredientes ácidos o herrumbrosos que le agregan algunos "chirriteros" actuales. Era como una tradición familiar, ya que el abuelo, el padre de papá, siempre tenía su "saca"

\footnotetext{
79 El "guaro de cabeza" es el que primero se chorrea de la "chirritera" y es más fuerte y de mejor sabor que el resto, a gusto de quien lo tome.

${ }^{80}$ Cerchas: la armazón hecha para pegar las láminas que cubren el techo de la casa.

81 "Jalarse una torta": expresión por cometer una falta o hacer mal una tarea, dañando algo preciado.

82 De la erupción de 1962.

83 "Madrigal" es la marca de una latitas de sardinas, que son importadas de Marruecos.
}

ISSN: 1659-0066 
en las fincas donde viviera. Solo me ha parecido el sabor de tal chirrite, al de un vodka polaco o finlandés.

Don Bartolo a veces se tardaba en pasar, pero papá se alegraba cuando el señor aparecía luego de varios meses. Generalmente era en las tardes. Después de una conversada, sacaba la botella para oler y probar. Otra conversona y el señor se marchaba con la alforja vacía o llevando algún producto de la pulpería.

\section{JUGANDO TABLERO}

Con una regla y un lápiz de carpintero, papá se puso a dibujar unos cuadros en un cartón y rejuntó un puño de chapas. Con esos invitaba a algunos de sus contertulios a jugar tablero. Yo me quedaba viendo. Un día me explicó como se jugaba (sin comer pátras) ${ }^{84}$, así que a veces me ponía a jugar con él. Luego me atrevía a jugar con algún "marchante" o caminante. Con el tiempo "me fui afilando", podía prever algunos movimientos y desarrollé algunas mañas. Comencé a ganarle a varios de los asiduos visitantes. El problema era que a veces me concentraba mucho con el juego y papá me regañaba por no atender a los clientes.

El problema fue mayor cuando comencé a ganarle a papá, quien "picado", poco a poco fue dejando el tablero a un lado y me hacía caras cuando me ponía a jugar. Sin embargo a Ramón, quien pasaba los viernes en la noche, le gustaba jugar, al inicio con papá, pero luego comencé a seguirle las jugadas y al tiempo no me podía ganar. De los güilas del barrio, solo algunos mostraban algún interés y se aburrían rápido.

Pero mi mayor entretención sería cuando llegaba Elena. Aunque poco llegaba a comprar, pues lo hacían sus hermanas mayores, a veces en las mañanas y otras menos al anochecer, llegaba a comprar un helado o golosina y nos quedábamos conversando. Cosas de la escuela o de la casa. Algunas veces nos poníamos a jugar tablero, con la consiguiente distracción que me ocasionaba mirar su cara de ángel y sentirme casi en retirada, asido de alguna nube, hasta que me ardían los cachetes.

\footnotetext{
${ }^{84}$ La modalidad de jugar "comiendo para cualquier dirección", o "para adelante y p'atrá", la conocí años después. Pero en el barrio nadie la jugaba.
} 
No pocas ocasiones la pulpería se llenaba de clientes y en mi desconcentración me olvidaba de darles atención, hasta el momento que papá daba la orden, golpeando a la par de donde sostenía mi codo. Así que a poquito y casi despistando Elena de pronto desaparecía.

\section{ARTURO: ENTRE EL CODO Y EL CARRETÓN}

Siguiendo la acera por la calle hacia el oeste, en la casa contigua vivían doña Amalia con su esposo, don Luis y sus dos hijos, Chavelita y Macho. Ellos se hicieron muy amigos de nosotros. Chavelita solía quedarse conversando con mi hermana, pues tenían la misma edad. Macho me era un año menor. Eran clientes fijos todos los días, aunque don Luis se desaparecía con un camión con el que iba por varios lugares del país. Eran buenos compradores de casi todo lo que podíamos venderles. Luego continuaba la casa de otra familia más numerosa: don Marcos y su esposa, de quien no conocí el nombre y pocas veces salía al barrio, sus hijos: Elsa, Ana, Jazmín, Carlos y la menor, a quién le llevaba dos años y me hacía saltar el corazón: Elena.

La tercera casa, luego de Elena, era un tanto angosta de frente. Una carreta lucía a veces en las tardes entre un estrecho jardín o al borde de la acera. Un señor moreno, alto, corpulento y un tanto mal encarado, pasaba a veces guiando un caballo con senda soga, desde la calle de tierra hasta esa casa o la ruta inversa. Arturo hacía uso de algunos lotes cercanos a la curtiembre, donde pastaban sus caballos. A veces por las tardes el hombre pasaba hacia el negocio de Pascual: trabajaba mucho, pero de igual manera, también "empinaba el codo". 85

En los primeros meses que iba con papá a los alrededores del mercado Central, me llamó la atención aquel señor, pues lo había visto en el barrio, pero por esa zona se le veía a la par de su carretón, cargando algunos sacos que parecían muy pesados, o acomodando algunas cajas para brindar un servicio. En esa zona eran varios los carretoneros, que competían en servicio con los camiones de carga y los "llevo llevo". Éstos últimos eran personas, muchas de ellos niños o adolescentes, que daban el servicio de "llevar" las bolsas a los compradores que andaban por los mercados y sus alrededores, a cambio de una propina o una suma según un acuerdo previo.

${ }^{85}$ La gustaba tomar licor con frecuencia. 
Toda esa es una zona de ebullición mercantil, donde entre otras cosas, se pueden surtir de los más variados ingredientes para cualquier olla de carne o ensalada de frutas. Los mercados principales son el Central y el Borbón. Ambos ocupan cuadras enteras. Pero entre ellos hay otros dos más pequeños: el que está al sur del Borbón, que no recuerdo el nombre, en donde comprábamos quesos, y otro al este de este, pues frente a la "taquería mexicana", donde a veces nos deteníamos a comer un par de tacos, había entradas hacia varias carnicerías y otros tramos entre los pasillos, que daban al frente de las pescaderías del norte del mercado central. También estaba la gran cantidad de casetillas de tramos provisionales en las aceras de los alrededores, además de quienes en una batea o simplemente sosteniendo en los brazos o con sacos y bolsas, ofrecen infinidad de mercancías, pero principalmente frutas y verduras. ${ }^{86}$

Casi todos los carretoneros se ubicaban al oeste del mercado Central, aunque algunos seguían un poco hacia abajo de la calle ocho por la avenida primera, que es la esquinera con el noroeste de ese mercado. Desde ahí se movilizaban a donde se requiriera el servicio.

Desde muy de mañana Arturo preparaba su carretón y se dirigía a San José, donde buscaba el sustento para su familia, entonces compuesta por su esposa Socorro, una hermosa, dulce y dicharachera morena de pelo tan largo, tupido y espeso, que le llegaba debajo de las caderas. Ella criaba seis hijos con poca diferencia de edades: Patricia, Marvin, Miguel, Carlos, Maribel, Ivania y Gabriela. Luego llegarían José Alberto y Luis. Esta güilada hacía parte imprescindible de las barras de jugadores de bola, bolinchas, billetes y tantos otros juegos. Además eran de los más osados y se aventuraban entre las pozas del río torres, los cafetales y los alrededores de la curtiembre.

Poco trato tuve con Arturo en los primeros años. Fue mucho más con sus hijos Marvin, Miguel y Carlos. Patricia era muy conversona con mi hermana. Yo trataba de no jugar a las bolinchas con Marvin, porque siempre lo hacía apostado y tenía muy buena puntería, de las mejores del barrio, aunque casi nunca le ganaba a Kiko.

\footnotetext{
${ }^{86}$ En esa época las ventas ambulantes ocupaban gran parte del espacio de las aceras y las calles de los alrededores de los mercados que se indican. Se construyó el "Mercado de la cocacola", donde se reubicaron muchos de los tramos, pero al poco tiempo, de nuevo abundaban tales ventas en la zona, pues las causas de su proliferación no han tenido atención apropiada, lo que se extiende hasta la actualidad. Pero ahora abundan en otros sitios de las calles principales de la capital, por donde deben caminar gran cantidad de peatones.
} 
Al cabo del tiempo Arturo y su familia se mudaron para una casita que en parte tenía piso de tierra, donde a veces se cocinaba con un anafre, otras con un fogón y pocas veces con otra fuente de energía. El cambio de casa ocurrió luego que en el gobierno de Figueres ${ }^{87}$ dieron fin a los carretoneros, pagándoles una indemnización de diez mil colones, con el fin que pudieran comprarse un camión de carga, con lo cual podrían "continuar trabajando".

Mucho estorbo era aquello para cierto sector social, que no veía bien eso de que en la segunda mitad del siglo veinte, sendos ejemplares ecuestres se pasearan por el centro de la ciudad capital, a veces dejando ciertos productos de su natural digestión equina, en medio de las calles y caños; pero además, haciendo competencia a los modernos camiones y camioncillos, que poco a poco iban dominando los servicios de transporte.

A Arturo la indemnización le alcanzó para un "perolito", recuerdo como un color rosado oscuro, y lo estiró lo suficiente para "montarse en la carreta", 88 que no soltó hasta que tuvo que pedir prestado. El "chunche" al parecer no funcionaba bien y no siempre podía costear los arreglos, así que se veían alcanzados para obtener el sustento. No podía volver atrás, porque además de haberse emitido alguna ley al respecto, tanto los caballos como la carreta, seguro fueron entregados a alguna autoridad, a cambio de la indemnización.

De alguna forma la familia sobrevivió, hasta que un golpe de suerte le dio a Arturo un gran aliento, cuando pegó un entero de "chances". ${ }^{89}$ No solo le alcanzó para hacer el cambio y comprar un mejor camión, sino también aquella humilde casita, en la que terminaría de criar a su prole con la ayuda de su buena suerte, pues un tiempo después, de nuevo "le pegó a los chances".

La casita se ubicaba siguiendo la acera de la pulpería, pero hacia el sur por la calle de tierra. Hasta donde supe y viví en el barrio, Arturo luego compró otro

\footnotetext{
${ }^{87}$ Don José Figueres, el candidato mencionado en el relato sobre una plaza pública, ganó las elecciones de 1970 y fue Presidente de la República hasta 1974, sucediéndole don Daniel Oduber, del mismo partido político.

${ }^{88}$ Expresión para indicar que "se fue de tanda", que es lo mismo que dedicarse a tomar guaro, u otra mezcla etílica, de manera indefinida. Tales periodos pueden durar desde unos pocos días, hasta algunos meses.

${ }^{89}$ Los "chances" son una forma de lotería que se juega los martes y viernes en la noche. La denominada propiamente "lotería", se juega los domingos.
}

ISSN: 1659-0066 
camión, que en una oportunidad y con motivo de las elecciones de 1978, él mismo me sugirió hacer una representación de la pobreza en que vivían muchas familias: aquellas que se aglutinaban, hasta hoy día, en tugurios en los alrededores de los puentes y terrenos incultos.

Con una pequeña brigada de jóvenes de la "J", entre quienes estaban Rafa Calderón, Fernando Rojas, Gabriela, Lupita y su hermano Eduardo, a quienes había reclutado en el barrio, además de una variedad de personas, algunas demasiado jóvenes pero que colaboraron espontáneamente; armamos una representación de tugurio construido con retazos de materiales de madera, zinc, cañas de bambú y cartón, que luciendo en el techo la bandera roja con la estrella blanca, desfiló por la Avenida Central, al son de canciones y consignas por un cambio social en la país. Arturo no solo prestó su camión, sino que ese día no trabajó y puso la gasolina, voluntad y empeño personal para el desfile de la noche.

Curiosamente, ni Pascual o doña Tere hacían uso de los servicios de Arturo para el transporte de mercadería, aunque a veces llegaban camiones con surtidos para su negocio. Papá tampoco lo hizo. No recuerdo tampoco que alguno de los vecinos recurriera a él para un transporte. Pero años después, cuando ya no vivía en el barrio, en dos oportunidades le pedí sus servicios para mi "traslado de casa", lo que hizo con gran cordialidad y colaboración.

En su senectud pude conversar con él, cuando salía a darme alguna vuelta en bicicleta y a veces pasaba por el barrio. Lo recuerdo al frente del que fue negocio de Pascual, ya convertido en una pequeña taberna. Nos sentamos un rato a conversar en la acera. Su mirada hacia lo alto, con los colochos hechos mechones. Se pasaba la mano por la frente y la barbilla, con un sentido profundo de esperanza y certidumbre en una mejor relación entre los seres humanos, solidaria, aunque con cierta amargura producto de una pobreza no superada.

\section{ENTRE EL MOSTRADOR, LAS BOLINCHAS Y EL "SALVA EL TARRO"}

No recuerdo haber dedicado un tiempo considerable a las tareas escolares, aunque si algunos repasos ocasionales, haciendo algunas tareas 0 preguntando algo a mi hermana. Sin embargo tampoco dedicaba mucho tiempo a jugar con la "güilada". Muchos de ellos llegaban a la pulpería y 
podían pasarse un buen rato conversando, esperando algunos de sus amigos, o simplemente mirando hacia la esquina del cine Reina. El solo hecho de estar en la pulpería era una manifestación de amistad y confianza, que no solo se reflejaba en los juegos.

Así que además de centro de tertulia, la pulpería era un sitio donde los chiquillos del barrio podían estar tranquilamente. Llegaban Carlillos, Rigo, Marvin, Uriel, Chimurria, Carlos, Bernardo, Kiko, el otro Marvin (quien llegó al barrio un par de años después), Chupadedos (otro Marvin). También Coqui, Marco, Alfredo, Jose y otros. Entre las muchachas estaban Nora, Patricia, Chavelita y Ana. En el barrio había muchas más, como Elena y sus hermanas, pero no participaban de las barrillas. Por supuesto las féminas eran mucho menos, pues además que eran mucho más "caseras", no tenían tanta libertad como los varones. Se aplicaba algo así como "el hombre puede andar en la calle, pero la mujer debe estar en la casa", aunque había unas pocas que igual participaban en diversos juegos de la güilada e incluso se iban hasta el río y los cafetales.

En la calle de tierra no solo se montaban las mejengas. Había otros juegos para los se prestaba. Cuando se juntaban era un enorme escándalo, y mayor si se ponían a jugar quedó o los partidos. Más tranquilo era con juegos como el llamado "puros", que era de los "grandes". Tomaban un palito, como del tamaño de un puro de tabaco o un poco más, se colocaba entre dos piedras y lo levantaban de un golpe con otro palo más grande, para luego hacer algo así como un "batazo" con el mismo palo grande, para enviarlo lo más lejos posible, apostando algo, como podían ser los llamados "cigarrets" o "billetes", hechos de las envolturas de cigarrillos.

A papá no le gustaba que anduviera con la barrilla, pero a veces "se hacía el maje ${ }^{\prime \prime 90}$ cuando salía un rato, pero más en la noche. Yo no tenía porqué "andar de vago", así que al rato tenía que meterme.

A veces me metía en el juego del "salva el tarro", una forma de "escondido". Era bastante popular y se jugaba en las noches, entre las siete y las nueve o diez. Se conseguía un tarro vacío de "jugos del campo", se le quitaba la etiqueta para dejarlo con el color metálico brillante y desde la esquina de la casa de doña Carmen, uno de quienes se escondían tomaba impulso y lo

\footnotetext{
90 Hacerse el desentendido. La palabra "maje" tiene otros significados, como el referirse a otra persona: "el maje ese, se hacía el tonto, para no dar el color". Pero en la frase indica no dar atención a un asunto.
} 
lanzaba hacia abajo de la calle, procurando lo más lejos posible. Casi siempre el tarro llegaba hasta el frente de la casa de Elena o la antigua de Arturo. De inmediato todos corrían a esconderse, aprovechando la sombra de la noche, los jardines, tapias y arbustos. El que buscaba, tenía que ir a recoger el tarro y colocarlo en un punto acordado, que era la esquina de la acera, para luego ir a buscar. Al encontrar a uno o varios, debían correr hasta el tarro, para "salvar el punto" y librarse de tener que juntar el tarro y luego ir a buscar de nuevo.

No todos los vecinos eran tolerantes con los juegos. Así que había jardines que no se podían utilizar. Uno era el de la casa contigua a doña Carmen, donde vivieron dos señores un tanto mayores, pero uno de ellos de mal humor. A veces si caía una bola en el techo o en el jardín, que tenía una cerca tupida de alambres de púas, se enojaba todo y no la devolvía. Pero había otros espacios, con arbustos, la forma de algunas fachadas de las casas y el pasillo hacia las casitas de don Gonzalo, que servían para los escondites.

Si terminaba el juego, o papá o mi hermana me llamaban, al regresar a la pulpería estaba lleno de tierra y a veces con restos de los arbustos donde me escondía, así que tenía que sacudirme para que no me vieran muy sucio.

Casi todos los carajillos tenían sus bolsas de bolinchas (o bolas de vidrio), aunque había algunos que destacaban en este juego, los más hábiles eran Kiko, Marvin, Carlillos y Uriel. El otro Marvin no era bueno y no le gustaban las bolinchas. Este era además uno de los artículos que se conseguían para abastecer la pulpería. En San José había varios almacenes donde las vendían "al mayoreo", por tantos de cien, que al vender "al menudeo", dejaban un margen de utilidad rentable. Yo aprovechaba cuando alguna "se picaba", es decir se le hacía una rotura, pues esas no las compraban y papá a veces me las daba. A veces venían los llamados "coquitos", que tenían ciertos colores y textura, pero más de blanco o anaranjado, que se podían vender a un precio un poco mayor, pues eran bien apreciados, aunque no recuerdo bien si era por ser de "buena suerte" o por ser "más bonitos".

Kiko tenía habilidades en las que era bastante bueno. Aunque no era de los niños que siempre andaba "chiroteando". ${ }^{91}$ Era un poco "verde"92 y tanto Nora como la mamá se preocupaban de que tuviera lo necesario y cumpliera con la escuela. Tenía gran habilidad para las "bolinchas" y otros juegos que

${ }^{91}$ Chiroteando: Por andar jugando o en incursiones por las fincas y el río.

92 Verde: por estudioso, aunque no era una expresión utilizada en la época. 
seguro practicaba en el jardín, o patio de tierra del frente de su casa. Con frecuencia andaba con su flecha en la bolsa. Los cafetales cercanos le proveían de "materia prima" para fabricársela, así como para andar punteando pajaritos entre los montazales. Solo requería dos o tres tiros y se los podía traer abajo. Un par de veces que anduve haciendo algún mandado por la calle luego de la curtiembre, lo observé con otros amigos y su flecha, de buena horqueta, se "punteaba"93 los pajaritos que podían estar en las ramas altas de los árboles y se los traía abajo. A veces pasaba con alguno en la mano y los acomodaba en sus jaulas. En eso se parecía al otro Marvin, solo que no los comerciaba. Pocos se atrevían a jugársela con las bolinchas, pues les podía dar desde la raya y sacarlas del círculo, cosa que también podían hacer Marvin y Carlillos.

En la calle estaban las marcas de los círculos y rayas que se utilizaban para jugar. El juego iniciaba "cazando" una o varias bolinchas en el círculo, desde el cual se lanzaba otra bolincha, la preferida por cada jugador, hacia la raya ubicada entre dos y cuatro metros del círculo. Quien lograra que su bolincha quedara más cerca de la raya lanzaba de primero de vuelta hacia el círculo. Luego que todos se habían devuelto, había que tirar haciendo puntería y de cierta manera, desde el punto donde había quedado la bolincha, contra las acomodadas dentro del círculo, para tratar de sacarlas y "apropiárselas". Tiraba primero quien hubiera quedado más cerca de la raya.

En ocasiones era necesario tirar contra la bolincha de otro jugador para alejarlo del centro y que así no pudiera ganar. Por esto algunos utilizaban un "balín", que era una "bolincha" de acero, supongo que obtenidas en talleres, de roles de cierto tamaño. Al ser más pesado quien tirara contra un "balín" tenía alguna posibilidad de que su bolincha se quebrara y "hasta ahí llegaba".

También podía ocurrir que quien utilizara un balín para jugar, a veces quebrara las bolinchas de otros jugadores, al tirarles para alejarlos del círculo. Pero los más habilidosos a veces tiraban con puntería desde la raya y si pegaban podían continuar con las demás bolinchas, hasta "estuzar"94 a los demás jugadores. Marvin, además de su puntería tenía otra ventaja: casi siempre disponía de uno o dos balines.

\footnotetext{
93 Punteaba: que acertaba el blanco con la flecha.

94 Estuzar: "dejar limpio", acabarle las fichas, ganarle el dinero o lo que fuera mediante la apuesta del juego, derivado seguramente de tuza, la cobertura o envoltura natural de las mazorcas de maíz.
} 
Otro juego de bolinchas eran las "chócolas". Consistía igual, en tirar hacia una raya, pero en vez de un círculo, había cinco "huecos" en la tierra en forma de cono volcánico invertido, uno en el centro y los otros a cierta distancia, como un metro, formando un cuadrado. Se iniciaba desde la raya procurando hacer caer la bolinche en el hoyo del centro o lo más cerca posible, y desde aquí hacia el primer hoyo y luego hacia los demás, siguiendo el movimiento de una aguja de reloj, hasta completar la ronda iniciando de nuevo con el del centro. Había que tratar de "ahogar" a los demás, golpeando con la bolincha propia a las rivales, para hacerlas caer en un hoyo que no le correspondiera. Quien lo lograra se adueñaba de la bolincha ahogada. A veces alguien podía perder un "balín" de esa manera. Si fallaba o de rebote caía en el hoyo que no correspondía en el orden, también perdía.

En la primera vuelta, el tiro se hacía desde el punto donde estaba la bolinche, pero en la segunda, se contaba una cuarta de la mano y desde ese punto se tiraba, ya fuera hacia el hoyo que seguía, o contra una de las bolinchas rivales, para tratar de ahogarla o simplemente alejarla del hoyo que le correspondía. Claro que en estos casos si fallaba podía quedar lejos del hoyo donde tendría que caer. Para la segunda vuelta se medían dos cuartas y así sucesivamente. Cuando se completaban varias vueltas, el uso de las cuartas (que era la distancia entre la punta del dedo gordo y el meñique con la mano "bien estirada"), la distancia iba siendo considerable, así que se podía acercar a las bolinchas rivales y así ahogarlas, para ganar el juego.

Yo no logré ser habilidoso con las bolinchas, aunque de vez en cuando jugaba, pero de "a mentirillas", es decir, que aunque perdiera no perdía mis bolinchas. Así lo hacía con "Macho", a quien tampoco dejaban andar con las barrillas. A veces jugábamos durante las tardes, en un pequeño espacio de tierra, donde la acera de nuestro frente estaba deteriorada. Hacíamos el círculo o los huecos para jugar chócolas menos distantes de lo normal.

Pero "Macho" hacía "chuzo", una forma de hacer trampa que consistía en tirar acercando la mano a la bolincha que se quería golpear y no desde el punto donde había quedado la bolinche. Además no podía hacer el tiro levantando la mano y apretando la bolincha entre la uña del dedo pulgar, sostenida por el dedo corazón, contra la punta del dedo índice, para impulsar el pulgar y poder tirar, sino que tomaba la bolincha con las puntas de los dedos índice y pulgar, haciéndolas tirar por la presión de ambos dedos, y además, "ihaciendo chuzo!". Pero de todas maneras jugaba con él. 


\section{UN SÁTIRO EN EL CAMINO}

Olguita no era vecina del barrio, sin embargo tenía cercanía con los Calderón, algo así como familiar lejano. El caso es que en una oportunidad que pasó a la pulpería, estuvo conversando un rato con papá. A algún convenio llegaron, porque al día siguiente, papá me dio las señas de la casa de la señora, para que fuera a recoger unas tortillas. No recuerdo cuántas eran, pero si que desde ese día debía ir hasta dos o tres veces, aunque no todos los días, a traer los paquetes de tortillas que la señora preparaba, para que fueran vendidas en la pulpería. Fueron bien apreciadas por la clientela de las mañanas y tenían buena salida.

Vivía en barrio Santa Eduviges, que era, con "señas a lo tico", bajando hacia la iglesia doscientos metros, luego una cuadra hacia el sur, había que doblar un poquito a la derecha y seguir de nuevo hacia el sur, donde luego de una pequeña cuesta la calle doblaba a la izquierda, hasta unos 25 metros antes del final, en que se topa con una curva del río Torres. Me parecía que la casa era grande, pues de la entrada debía bajar una gradita, que era como el sótano de la casa convertida en una "planta baja", donde tres o cuatro muchachas "le daban parejo" a la palmeada de tortillas y salía ese aroma particular, de entre las brasas y los comales. ${ }^{95}$ Todo el sótano parecía un taller, con fogones, mesas y máquinas de moler y fregaderos que, dando a un patio abierto, colindaba con un pequeño cañón del río. Me daban el paquete de tortillas según las indicaciones de Olguita, y al "ratico" que las féminas me bromeaban, salía rápidamente, no fuera que se enfriaran mucho mientras regresaba.

A los pocos días me percaté que llegaba más rápidamente, pues me ahorraba más de doscientos metros de ida y otros tantos de regreso, si en lugar de dar la vuelta por la entrada de aquel barrio, solo bajaba una cuadra desde la pulpería, tomaba por la izquierda y llegaba al final de la calle anterior, luego de una pequeña rotonda bajaba por un lote grande, donde abundaban las "lágrimas de San Pedro". Entre un caminito salía al final del barrio, donde la calle se encuentra con la curva del río, teniendo que subir por un empedrado. También podía pasar por un pequeño puentecito de

95 Comales: forma de un sartén, redondo y casi plano pero con una inclinación hacia el centro, que se utilizaba para freír en los fogones, fueran tortillas, hacer gallo pinto, huevos y otros platillos.

ISSN: 1659-0066 
cables y madera, que tenían instalado los residentes de unas casitas de madera, cuyas paredes se inclinaban un poco hacia la pendiente con el río. Llegaba bastante más rápido y de paso contemplaba un poco la corriente del río y el pequeño montazal que se formaba en aquel lote.

Me llegaron los rumores de que por ahí rondaba un sátiro. "¡Le va a salir pichiguri!", me decían. Al principio no sabía a quién se referían, ni en qué consistía la amenaza. Cuando "me cayó la peseta"96 ya habían pasado varias días que seguía esa ruta corta. Pero como no había visto gente rara y menos algún "chingo"97 por el sitio, no le di importancia a las expresiones. Aunque sentía un poco de temor, pocas veces volví a hacer el recorrido por la calle.

Era un señor de cierto aspecto desagradable: corpulento, moreno, alto y un tanto encorvado, la cara picada de cicatrices, como quien luego sería conocido en "La Patada"98 como "Cara de Piña" o "Garapiñado". Siempre andaba de saco y corbata, lazo en el cuello o corbatín, notándose como prendas ajadas. Se amarraba el pantalón con tirantes elásticos y la pretina se la acomodaba por encima del obligo, lo que le resaltaba la barriga y le daba un aspecto entre cómico y amenazante, aunque siempre mantenía un porte de muy serio y comedido.

De vez en cuando llegaba a la pulpería, proveniente de y hacia cualquier rumbo, compraba unos diez puros, de los mismos que don Alfredo, sacaba una cuchilla tipo "lora", 99 le hacía el corte a uno y lo encendía, iniciando a despedir el humo y hedor característico en medio de la pulpería y se iba.

\footnotetext{
96 Por caer en la comprensión. "Por fin le cayó la peseta". Deriva del uso de esas monedas, como el costo mínimo para las llamadas telefónicas. En su momento para hacer sonar la música de los discos de las "rockolas", se utilizaba una moneda de cincuenta céntimos, más conocidas como "cuatros", por ser cuatro reales. Las pesetas eran dos reales y los 75 céntimos, seis reales. Estás últimas son expresiones heredadas posiblemente del periodo colonial. Entonces también se usaba la expresión: “¡Ya!, al fin del cayó el cuatro", por alguien que no había comprendido o se hubiera percatado de algo.

97 En referencia a un hombre desnudo, o exhibiéndose con intenciones obscenas.

98 "La Patada", fue un programa radial muy reconocido por su sentido crítico de la realidad del país, particularmente con el fútbol, los diputados, los gobernantes y personajes sobresalientes de la vida nacional. Fue dirigido por un inmigrante colombiano, don Parmenio Medina Pérez, quien fuera asesinado por alguno de los muchos a quienes dirigió las críticas de su programa. "Carepiña" o "Garapiñado", era el sobrenombre con que ahí hacían referencia al General Manuel Antonio Noriega, tomado preso por los invasores del ejército norteamericano en 1989, bajo el cargo de supuesto narcotraficante.

99 Especie de navaja o cuchillo, que se dobla para guardar en el mango, con una punta particular similar al pico de las loras o pericos, de unos doce centímetros de largo, por lo que parecen amenazantes.
} 
Tales puros, aunque a veces se compraba un paquete de "chesterfield" mentolado, que luego cambió por los "Quijote". ${ }^{100}$

A veces conversaba un poco con papá, pero utilizaba un tono distinto según quien le atendiera al llegar. Para mí y con mi hermana, con su voz grave sonaba un tanto fuerte y autoritario; como que no le gustaba que le atendiéramos. Con papá no era grosero, sino un poco ameno, formal y amigable, iniciaba algún tema comentando algo sobre la situación nacional, de la comunidad o el cantón, mientras sostenía una de las manos entre la bolsa del saco o del pantalón, que le hacía juego con el enorme saco. Daba un aire de autoridad y conocimiento en lo que decía, mientras con la otra mano hacía énfasis en sus palabras, sosteniendo el puro o cigarro a veces con los dedos, a veces entre los dientes o los labios, aunque no necesariamente lo tenía encendido mientras conversaba.

Decía que era abogado y algo hablaba de leyes. Ese aspecto de seguro trataba de transmitir, por la formalidad con que hablaba. Casi siempre, si era un puro, lo encendía cuando ya casi se iba a retirar. Tomaba su encendedor de bencina y tapando la llama con ambas manos, jalaba aire para que encendiera bien haciendo buena brasa y "golpeando un poco". ${ }^{101}$ Hacía sonar el encendedor al taparlo y se lo guardaba en la bolsa interna del saco, mientras exhalaba la bocanada de humo.

Cuando iba como a cincuenta metros, a veces algún "carajillo" acompañado de otros dos o tres, gritaba desde la esquina: "ipichiguuuri, pichiguuuri!" y salían corriendo sin esperar a que el señor al menos volviera a ver, para quizá reconocer a quienes pretendían burla, sin percatarse que aquel hombre, seguro ni se daba cuenta del pretendido insulto.

El caso es que nunca llegué a ver al señor por el mencionado lote, ni siquiera en saco y corbata, aunque decían que por ahí se escondía y le salía a los güilas. Solo a veces me lo topaba cuando caminaba por los alrededores de la entrada de ese barrio, o entre el parque y la pulpería, siempre de saco y corbata, aunque se estuviera a pleno sol.

\footnotetext{
100 Estas eran marcas de cigarrillos. El Quijote se caracterizaba por la longitud, más extensa que la generalidad, lo que los hacían más rendidores al consumidor, además era mentolado.

101 Golpeando: haciendo llegar el humo a los pulmones.
}

ISSN: $1659-0066$ 


\section{GASTANDO ZAPATOS}

Luis era un hermano menor de Arturo. Vendía lotería y hacía su jornada pregonando por las calles, desde los bajos de la Cuesta del Marcelo, hasta los barrios del centro de Guadalupe, principalmente al lado sur, aunque a veces se iba hasta Moravia. Papá le compraba el 33 y el 35, y muchas veces se quedaban echando habladas de los caminos andados por uno y otro. Era un hombre joven y se jactaba de las ventas que hacía en sus caminatas.

No pocas veces se quejaba del desgaste de sus zapatos y de alguna chimazón por la horma y las mojadas. Aunque en época de lluvias cargaba una capa amarilla en su bolso de tirantes, decía que se le hacían yuyos o se le rompían las medias.

Una vez papá le sugirió que si quería probara con los zapatos que hacía un hermano. Mi tío Juan siempre dejaba muy en alto el apellido en los barrios donde le tocó vivir, pues no más llegaba, con un cartón o pedazo de madera hacía un rótulo: "Zapatería Elizondo" y la remendona comenzaba a funcionar. Para efectuar ciertas costuras debía ir donde Bolívar, ${ }^{102}$ porque no tenía máquina. Utilizando únicamente cuero, hacía los zapatos a mano, heredando oficio y habilidad a sus hijos.

Papá hizo el encargo y un día se los entregó, aunque no había tomado las medidas como era su costumbre, sino que le consiguió unos del número que Luis dijo. Se los probó y se sintió cómodo. Varias semanas después, un día que el Tío estaba de visita pasó Luis y se conocieron: "Ahora si tengo buenos zapatos, no esa cochinadas que venden ahora, les dura el tacón y la suela ... y no se les mete el agua". El tío se puso a explicarle algunas de las técnicas y los materiales que usaba, y "bueno, esos son bien pegados y para que queden mejor, luego van cosidos".

A partir de entonces Luis era un cliente de los zapatos, además del medio paquete de delta y de vez en cuando una coca con tres bollos de pan y dos rodajas de mortadela de donde "Chico Chulo". ${ }^{103}$

\footnotetext{
102 El de Bolívar era un taller de costura de zapatos, ubicado en la calle entre los barrios Santa Cecilia y San Gerardo, donde tenían varios tipos de máquinas para coser.

103 "Chico Chulo" era una carnicería especializada en embutidos, ubicada en una especie de "mercadito" al oeste del mercado central.
} 


\section{APRENDIZ DE ELECTRICISTA}

Mario era de la familia Calderón, algo así como primo de los padres y madres de la güilada, joven y muy afable, trabajaba en una de las fábricas de las cercanías de San Francisco, por Calle Blancos. Por las tardes era usual que pasara un rato a la pulpería donde se compraba un par de deltas y se quedaba fumando. En alguna ocasión papá comentó algo sobre la necesidad de una extensión eléctrica para mover uno de los congeladores, pero que no sabía como hacerlo y necesitaba que alguien le ayudara. Mario escuchó la conversación y muy amablemente se ofreció a poner el tomacorriente.

A pocos días papá me mandó a la ferretería de Chalo, "El Mazazo", que entonces quedaba a la izquierda de la entrada al cruce a Moravia, a comprar el material que Mario había solicitado.

Así que una tarde se puso a hacer la instalación, mientras yo, "de voluntario" estaba ayudándole y poniendo atención, como hacía para tomar los cordones eléctricos, encontrar el punto para cortarlos, luego amarrar los de la nueva extensión, cubrirlos con el tape uno a uno, pegar y atornillar el "toma" y probar con un aparatito que traía.

En otra oportunidad fue la colocación de un bombillo, para que alumbrara la romana que papá había instalado colgando sobre una de las esquinas del mostrador. Le preguntaba a Mario cada movimiento que hacía y él poco a poco me explicaba, como colocar los cordones y amarrarlos y evitar un circuito. Aprendí a no tenerle miedo a los cables, aunque no pocas veces los hice chocar con el consiguiente chasquido y chispero. En alguna oportunidad hice alguna extensión para algún tomacorriente.

Luego, como era usual, en primer año de colegio, el profesor de artes industriales "amplió mis conocimientos" y aprendí otros trucos para que no se soltaran y también a cuidar de no recargar la instalación. Por cierto en una casa de madera, eso era muy importante, aunque creo que no tenía mucha conciencia del peligro. 


\section{UNA SEÑORA DE FEA CARA Y MAL CARÁCTER}

Casi todas las mañanas doña Toña llegaba a comprar medio paquete de ticos, una bolsita de citrato ${ }^{104}$ y una onza de café. A veces con tres bollitos de pan y una onza de mantequilla o una peseta de queso. Si no había ticos le gustaba el dominó ${ }^{105}$. Vivía en una de las casitas al final de la calle de tierra. A media mañana salía y regresaba a media tarde. Seguro se ganaba algunos "camarones"106 en oficios de la casa. No siempre tenía dinero, por lo que de vez en cuando pedía fiado, aunque a veces parecía que se le olvidaba y si no se le cobraba no pagaba. No usaba libreta porque decía que se le olvidaba traerla, pero de pronto no se acordaba y ponía en duda la deuda. Cuando eso ocurría, papá le mostraba en el cuaderno, la hoja donde estaba el nombre de ella y le indicaba la fecha y a veces la hora de cuando adquirió la deuda.

En una oportunidad pasó en la noche, cuando papá no estaba. Pidió algunas cosas y me dijo que se lo apuntara. Pero papá me había advertido de no darle fiado a nadie, salvo a doña Carmen y doña Amalia. Discutí con la señora. Le dije que no podía darle fiado, que papá no me dejaba. Discutiendo y discutiendo, de su tradición de comprar fiado y que siempre pagaba: "qué desconfiado". "¿qué es eso? su papá siempre me ha dado fiado" " $i Y$ yo soy muy, muy honrada!". " $M e$ gano muy honradamente lo que me como!"

Y ahí seguía, que tenía que darle fiado. Que no tenía porqué negarle lo que ocupaba. Qué desde los tiempos de doña Dora y que llamara a Abuelita... Y yo: que ella está acostada y que no podía darle fiado porque papá me iba a regañar... Qué su papá siempre me da fiado... Qué como le iba a dar fiado si ella solo compraba medio paquete de ticos y una onza de café... Y la señora más enojada. Porque era muy buena clienta, que solo a nosotros nos compraba... Qué porque la trataba mal si ella era buena persona...

En una de esas le recordé algo que se había negado a pagar y luego que papá solo me dejaba darle fiado a doña Amalia y a doña Carmen y ahí la

\footnotetext{
${ }^{104}$ El citrato era un medicamento utilizado para ciertos males del estómago. Venía en unos "colochitos", o palitos, blancos y pequeños, en bolsitas transparentes con alrededor de una onza de peso. Se disolvía en agua o se podían comer los pedacitos, pues me parecía que tenía buen sabor

105 Marcas de cigarrillos, que eran los más baratos y eran sin filtro.

106 "Camarón": Realizar algún trabajo o servicio, generalmente de manera ocasional y que se paga a convenir al momento de concluirlo.
} 
señora reventó... "¡Qué, ... como era posible que a esas señoras sí, y a ella no...!" Cómo era eso, si ella era una mujer honrada. Y empezó el reclamo porque eso no podía ser. Qué barbaridad, iba a hablar con papá... Ahí si metí la pata...

La señora no se pudo llevar lo que quería y se fue bien enojada conmigo. Al día siguiente, a media mañana estaba reclamándole a papá. Qué porque no le daba fiado, Porqué me decía a mí que a doña Amalia y a doña Carmen si les podía fiar lo que quisieran y a ella no. Y papá que me miraba con sus ojos verdes a punto de relámpago. Así que me preparé de todas maneras para la regañada.

La señora a veces parecía recapacitar. Entonces recordaba, que ella siempre había pagado y que nunca había quedado debiendo un cinco a nadie. Que ella era muy honrada. Que si necesita algo, porqué se le va a negar, si ella tenía que trabajar para comer, que no era ninguna malacostumbrada y etc... etc... Papá solo le decía que ella a veces no pagaba, pero no le decía que le iba a dar fiado de nuevo.

Luego que la señora se fue a sus trajines vino "la tarabilla"107 conmigo: qué como se me ocurría decirle que si le fiaba a las otras señoras y a ella no, que eso solo era para la señora, pero que tenía que tener cuidado con lo que decía... Y qué porqué le decía que era mala clienta. Qué cuidado con lo que decía...

Doña Toña pasó muchos días que no compraba nada. Pasaba directo. Donde Doña Tere tampoco compraba.

\section{CON AROMA DE MAÍZ}

Algunos pocos meses fueron los que debí estar en el mandado de las tortillas al barrio Santa Eduviges. Llegué a distinguir a algunos de los vecinos de aquella casita donde se vivía de la palmeada cotidiana y mañanera, así como a quienes vivían a la orilla del puentecito de cables y madera.

Ocurrió que a nuestro barrio llegó a vivir Alma, quien era de esas mujeres decididas y curtidas por el trabajo diario, necesario para mantener y criar a

107 Tarabilla: "perorata", o una conversada a manera de regaño o reclamo.

ISSN: 1659-0066 
sus cuatro hijas, cual más de simpáticas y picaronas, aunque recatadas y estudiosas. Tenían el pelo claro, como que si el maíz les hubiera formado en su contextura y presencia. La menor de las niñas se parecía más en el carácter a su mamá, además de sus ojos verdes como la mazorca del elote tierno. Todas ellas se convirtieron en nuestras amigas, aunque más de mi hermana y a veces pasaban sus ratos en la pulpería, o muy de vez en cuando, jugando cromos o "yacses" por la otra entrada que tenía la casa.

A veces a media mañana, otras al caer la tarde, pasaba Alma con sendo balde en el hombro, lleno de maíz ya cocinado, a veces con un pañuelo rojo o blanco amarrándole el pelo, lo que le resaltaba las arrugas en una frente un poco ancha, con dirección a algún molino, aunque ella tenía su molino de mano y las muchachas le ayudaban en la palmeada. Un par de horas después regresaba con el maíz convertido en masa.

Habría ofrecido sus tortillas y papá le encargaba para vender en la pulpería. Quedando más cerca y no teniendo yo que estarlas trayendo desde otro barrio. También fabricaba tamales de chancho o de pollo y delicioso "tamal asado". Entonces llegaba: "voy a hacer tamales, ¿Cuántos le traigo para que venda?". Otras veces: "El sábado hago tamal asado, usted dice si les traigo un par de bandejas, verá que se le venden rapidito". Y efectivamente así era.

También encontraba tiempo para mas de una conversona con papá y otros contertulios, sin faltar con sus propias anécdotas. En ocasiones de alguna pescoceada o trajines vividos en otros lares. Sus manos empuñadas podían dar fe de algunos de sus relatos y el porte de su presencia imponía respeto y a la vez consideración. No daba lugar a dobles entendidos ni a las medias tintas.

Además que nos surtían tortillas y ocasionalmente otros productos, eran nuestras clientas y compraban bastante para sus necesidades diarias, de vez en cuando con libreta y otras de contado. Alma era mujer de palabra, que "no le ponía peros a la vida", ni se amedrentaba por las tribulaciones. El sudor de su frente reflejaba la honestidad y dedicación a su trabajo y la rigurosidad que marcaba su vida y la de sus hijas.

Tenía los brazos tan fuertes como cualquier hombre y lo mismo le daba palmear las tortillas, como tomar un martillo, alicate, pala o serrucho para 
hacer cualquier arreglo que requirieran la casita que alquilaba, o los medios que utilizaba para su trabajo. Alguna vez la observé arreglando algunas goteras, el bajante, la canoa o la techumbre sobre parte de un jardín que también mantenía bastante presentable. Si alguien le ofrecía cierta ayuda, respondía que ella podía hacerlo y que muchas gracias. No le aguantaba nada a nadie y aunque respetuosa, no le faltaban las palabras más apropiadas para responder ante cualquier insinuación hacia ella o sus hijas.

Lo mismo salía a distribuir el producto de su trabajo, que con el apoyo de sus hijas nunca les faltaba, ni los deseos de que les sobrara.

\section{DONDE PONE EL OJO PONE EL CACHIRULO}

Con la venta de cigarrillos al menudeo quedaban muchas "cajetillas vacías". ${ }^{108}$ Al tiempo me di cuenta que el papel plateado que recubría los cigarros dentro de cada cajetilla, era un excelente material para la fabricación de "cachirulos". ${ }^{109}$ En el barrio era otro de los juegos más populares y se armaban trifulcas entre grupos de carajillos, que se hacían guerra por las calles, utilizando los postes y los jardines, tapias o arbustos para protegerse.

Como yo estaba detrás del mostrador no podía andar en esas guerras, pero podía practicar. Disponía de buenas ligas y podía calcular la tensión entre los dedos índice y pulgar, desde donde doblaba la liga para cruzarla formando el arco, ubicar el punto donde colocar el cachirulo, procurando que fuera en el centro, con una tensión similar a ambos lados, luego jalaba la liga al nivel del ojo para apuntar y tensar lo suficiente, para que el proyectil llegara al punto donde deseaba, sin que se fuera a reventar la liga (no fuera que me pegara en el ojo), logrando bastante precisión.

De vez en cuando hacía guerras con algunos de la barrilla, principalmente con Marvin, Miguel y Rigo. Podía batirme con dos o tres a la vez, pues ellos desde la acera se protegían con la puerta y yo con el mostrador y los frascos de confites. Poco me pegaban, pero a más de uno le dejaba picando los brazos, las manos o algún cachete.

\footnotetext{
${ }^{108}$ Cajetillas: los paquetes o envoltorios de los cigarros.

109 El "cachirulo" se fabrica doblando con cuidado trozos de papel de unos 6 por 4 centímetros, formando un tubito, que se dobla en el centro, creando una especie de grapa o arco, que se coloca en una liga, que se estira de cierta forma con dos dedos de la mano, para impulsar el cachirulo a manera de proyectil, contra un blanco determinado.
} 
Como disponía de las cajetillas de cigarros, les daba un doble propósito: las cajetillas se convertían en "billetes", aunque no muy valiosos, pues los más populares eran "delta", "capri" y "ticos". Marcas como "rex" y "chesterfield" no se vendían mucho, aunque la cajetilla podía cotizarse en quinientos, mientras que delta y capri valían solo cien y ticos (un cigarrillo sin filtro y el más barato) valía cincuenta. Era un valor considerable, porque en esos años quienes trabajaban en fábricas o en comercios como dependientes, podían ganar alrededor de cien o doscientos colones por quincena. Como el "dominó" no era muy común, se podía cotizar también en quinientos, pero un "liberty", que nosotros no vendíamos, se cotizaba en mil, igual que el "kennedy", el "viceroy" y el "emu". Los sin filtro eran las marcas "ticos", "dominó", "león" y "liberty". Solo vendíamos ticos y león. Estos se jugaban como si fuera un casino callejero, tirando de raya a raya, jugando "cuartas" con una moneda o "puros".

El otro propósito era utilizar el papel plateado que protegía los cigarrillos en cachirulos. Cada envoltura la partía simétricamente en cuatro partes y cada una se convertía en un "poderoso cachirulo". Enrollaba y doblaba para darle la forma de grapa y quedaba bien duro, a la vez que flexible para apuntar con la liga. Las galletas para vender en paquetitos, como esas de cremitas pozuelo, las comprábamos en cajas, que traían no recuerdo si cien o cincuenta paquetitos, pero al desocuparse tenían varios usos. Así que utilizaba una para almacenar cachirulos y nunca me faltaban.

En una oportunidad que estaba solo en la pulpería, eran más de las siete y media de la noche. Macho, andaba con ganas de jugar. Se escondía tras la puerta hacia la acera de su casa y de pronto me tiraba un "cachirulazo" y se volvía a esconder. Así que al rato busqué una liga y comencé a responderle, comenzando el intercambio de proyectiles. Pero como "me había picado", pensé que me lo "apiaría"110 en un cachete, un ojo o la nariz. Me dispuse a apuntar con cuidado en el punto donde él asomaba para tirar. En el momento que asomara lanzaría mi proyectil. En varias ocasiones, le di al borde de la puerta o los cachirulos seguían hacia la calle, pero en una que lo dejé asomarse un poco más le dejé ir. Y qué más decir: exactamente en el ojo

\footnotetext{
110 Apear, más bien "apiar", se usa mucho por algunas zonas rurales, como sinónimo de bajar. "Se apea del caballo", "Aquí me apeo del bus". También para indicar acierto de un proyectil, por ejemplo: "apiarse un mango" con una piedra o palo. "Se apió un gavilán con el balaú", que mató o cazó un gavilán con un rifle de ese tipo.
} 
y Macho echó a correr pegando alaridos y aterrado, mientras agachado se ponía su mano en el ojo herido.

Al poquito rato llegó Chavelita, diciendo que le había "reventado el ojo", que estaba echando sangre y que doña Amalia hablaría con papá en cuanto llegara. Así que me quedé asustado, esperando ver a macho echando sangre por donde había tenido su ojo, que me lo imaginaba como un huevo reventado, desparramando sangre. $Y$ a doña Amalia regañándome reclamando por el ojo de su hijo. Papá llegó tarde, casi a medianoche y dormí con el miedo de lo que ocurriría al día siguiente.

Efectivamente, doña Amalia no llegó temprano como otras veces a comprar el pan. Empecé a preocuparme más, pensando si Macho estaba en el hospital. Sería como las siete y media de la mañana, cuando llegó doña Amalia como una tromba (era una señora corpulenta y alta). Con pocas y alzadas palabras, en pocos segundos narró a papá su versión de los hechos y que Macho estaba muy mal del ojo por mi culpa. No había salido la señora de regreso a su casa, cuando sentí los "mecatazos"111 de papá y ahora fui yo quien sonoramente se quejaba de los verdugones en la espalda.

Pocos días pasaron para que, quienes integraban esa familia de nuevo compraran en la pulpería. Entonces de nuevo Macho apareció con sus dos ojos bien azules y su pelo casi rubio, otra vez con los cachirulos. Pero mi caja la guardé en mi propio escondite del cielo raso, no fuera que papá me fuera a botar los proyectiles que con tanto afán me había construido. Seguí practicando y tomando más puntería, pero pocas veces volví a jugar de guerras. Y a Macho nunca más le volví a "dar pelota".

\section{UN VIEJITO SIMPATICÓN Y PICARÓN}

Don Gonzalo tenía una serie de casitas con una entrada de acera, ${ }^{112}$ como a cincuenta metros al sur de la casa esquinera de doña Carmen. La propiedad tenía tapia de "láminas de zinc" a la entrada, pero sin portón, de manera que cualquier persona podía entrar. Yo acudía con frecuencia a dejar o hacer algún encargo a quienes ahí vivían, entre ellos don Gonzalo, en la casita de más al fondo a la derecha. Desde la entrada era como un zaguán con seis

\footnotetext{
111 Mecatazo, que pega o golpea con un mecate o soga de ganado.

112 El pasillo hacia las casitas tenía piso de concreto, similar al de las aceras de las calles.
} 
casitas con sus jardines a la izquierda de la acerita, cada una separada de la otra por fuertes barandas de madera pintadas de colores. Al fondo se formaba una $T$, de manera que a la izquierda había dos casitas y tres a la derecha. Eran pequeñas, pues solo tenían un cuarto o solo era una salita con una cocina y las pilas, pero casi siempre vivían solo una o dos personas, quienes con cierta frecuencia las desocupaban y llegaban otras.

Alto, de ojos celestes y pelo canoso y escaso, la frente le daba poco espacio a las arrugas, pero su voz grave, fisonomía facial y las cejas tupidas no dejaban especular sobre su poca o mucha ancianidad, pero si de su animosidad, bonachonería y solicitud.

Don Gonzalo acudía a comprar de todo lo que requería para desayunar o prepararse una cena. Como otros vecinos, gustaba de irse a "esquinear" en la pulpería a media mañana, mientas contaba chiles o anécdotas con papá o mi hermana. Conmigo vacilaba y a veces se ponía a jugar tablero, aunque sin darle mucha importancia al juego y sí a la conversona. De pronto yo me ponía a hablarle en "Ka", que había aprendido cuando vivía en Villa Ligia, pero que Nora había introducido en el barrio, explicando a mi hermana como se intercalaban las sílabas con la "K". Ella además usaba otras sílabas, como "Ke" o determinadas palabras ininteligibles o desconocidas, como "diara" o "anahuara" lo que hacía difícil entenderle.

Cuando me ponía a hablarle "en K" a don Gonzalo, de pronto le llamaba por su nombre y le decía alguna cosa, para que no me entendiera. Reclamaba y le decía a papá, "oiga que chiquillo malcriado como me está diciendo", que si tomé café y que ando "cagón". "A él que le importa. Ja ja, jaaa, óigalo, cómo dice esas cosas ..." y se me quedaba viendo como si hubiera dicho un chiste, se reía a carcajadas.

Papá me volvía a ver con el rabo del ojo y seguía en sus cuentas, como tratando de descifrar lo que decía, pero sin darle importancia, mientras le seguía la charla al anciano.

A veces pedía unas tortillas y queso en tajadas, y ahí mismo se hacía unos gallos y los engullía. Se pedía una "kola" o una botella de leche y ahí se la tomaba acompañando sus gallos o "sángüiches". En otras, helados de palillo, de los que se comía varios. Luego se quedaba conversando un buen rato. 
De vez en cuando pasaba con un cuchillo, seguro a ganarse algún camarón, pero casi todo el tiempo estaba en su casita o dando vueltas por el vecindario. Tenía sus entraditas con el alquiler de las casitas y posiblemente alguna "guaca"113 en algún rincón. Aunque nunca entré al fondo de las casitas, seguro tenían un patiecito y supongo que al fondo daban con los lotes donde Arturo pastaba los caballos y la güilada se aventuraba "en busca de tesoros".

Mucho pesar nos causó, cuando un día nos dimos cuenta que lo habían "despachado para el otro lado". ${ }^{114}$ Algún malviviente ${ }^{115}$ había supuesto que el viejito tenía algo guardado y lo sorprendió a la sombra de la noche.

\section{SERENATA EN EL DÍA DE LA MADRE}

Siendo una familia un poco grande y ocupando varias casas del barrio, los Calderón tenían otras tradiciones. Claudio era uno de los hijos de don José Luis y doña Nena, quizá el que menos se veía o escuchaba en el barrio, pues también era músico, con melodiosa voz de uno de los conjuntos musicales más reconocidos de esos años en el país. Su familia era de las más tranquilas, con dos niños en la escuela, más caseros que de andar en las "barrillas", dedicados a sus tareas y la ayuda a su mamá, quien era una de las clientas diarias de la pulpería, con libreta y cuaderno, comedida y digna de la mayor confianza.

Pocas veces Claudio pasaba a la pulpería, a diferencia de su esposa y sus hijos, quienes llevaban variedad de productos y en diversas cantidades: no faltaba la onza de café, la "peseta" de pan y la otra de numar, un cuarto de salchichón y algunas papas, tortillas, su botella de leche, libra de azúcar y media de frijoles y otro tanto de arroz. Aunque no todo lo compraban a la vez, sino que varias veces en las mañanas llegaban Cuyo, Tano o la misma

\footnotetext{
113 Guaca: por la similitud con las "huacas indígenas", que los "huaqueros", personas que buscaban cementerios indígenas que desenterraban, con afán de encontrar piezas valiosas de oro, jade u otras, que luego comerciaban, destruyendo los sitios arqueológicos. Aquí se asimila por tener dinero escondido. 114 Fue asesinado para robarle.

115 Por referirme a la persona que lo asesinó. Se usa para personas que no tienen ocupación sana, sino que andan buscando a quien robarle sus pertenencias, como ladrones, asaltantes u otras actividades delictivas.
}

ISSN: $1659-0066$ 
doña Ana, a llevar lo que ocupaban para el desayuno, el almuerzo o el café si era en la tarde.

Cada madrugada del 15 de agosto, alrededor de las tres o cuatro, el sueño de muchos en el barrio era interrumpido por la melodiosa voz de Claudio, acompañado de varios instrumentos musicales,

\author{
"Tiene los cabellos blancos \\ Muy arrugada la frente \\ Pero es la más bella \\ De todas las mujeres \\ Cuando niño me mecía \\ En sus brazos amorosos \\ Y todas las noches \\ Rezábamos juntitos \\ Oye, la canción más sentida, \\ Que feliz este día \\ Te da mi corazón... "
}

Cuando me despertaba, el conjunto llevaba algunos acordes adelante. Solo me quedaba escuchando, como seguro lo hacían papá y mi hermana, en silencio, la dedicación que aquel hombre humilde y sencillo hacía, como todas las personas que integraban aquel "familión", a su anciana madre y con ella, a todas las del barrio, incluyendo abuelita.

El conjunto llegaba, acomodaban los instrumentos y los "bafles" en el jardín, la acera y parte de la calle de tierra. Y por varios minutos entonaban canciones dedicadas a las madres. Luego, seguro se tomaban un cafecito o un rompope y continuaban con la siguiente serenata, a otra madre. Podría haber otros compromisos que cumplir, pero ese día la atención a sus progenitoras era lo más importante para cada integrante del conjunto.

Algunos de los residentes del barrio acompañaban a los Calderón en aquella dedicatoria y buena algarabía se formaba en la madrugada.

La serenata de Claudio y su conjunto era la única que se escuchaba en ese día. El radio transmitía programación especial y durante los días cercanos, en la escuela se cantaban canciones dedicadas a la madre, como el "Himno a las madres" y "Santa y bella", y seguramente, hasta se realizaba un acto especial. Los Gutiérrez también tenían algarabía, pues la anciana madre también los 
acompañaba y en todas las casas se sentía el ambiente de fiesta. Lo mismo en otras familias, algunas más grandes, otras más pequeñas, con sus madres y abuelas: Rosita, Socorro, Ana, doña Tere, las dos doña Carmen, doña Amalia, Marta, Joaquina, Alma, las dos Cecilias, doña Rosa y tantas otras.

Como otros días feriados, la festividad se sentía durante todo el día y el respeto y consideración a las madres era la tónica con palabras amables y de felicidad para ellas.

Por alguna razón, ese también era un día de bastante movimiento en la pulpería. Aparecían clientes desconocidos de otros barrios y llevaban las cosas más variadas y buscaban productos que no siempre teníamos. Como decía papá, había que "ponerse águila", ${ }^{116}$ porque a ratos hasta abuelita tenía que venir a ayudarnos a dar abasto con tantos "marchantes", como por su lado decía mi tía, quien a veces, en esas épocas nos visitaba desde Guatemala. También ella colaboraba en la atención, aunque no sabía la ubicación de muchas cosas y menos de los precios, un poco se descontrolaba por la diferencia del cambio con el "quetzal" (entonces a la par del dólar), pero bien ducha para sacar cuentas y dar vueltos.

Para papá ese día era de lo más importante, pues era ceremonioso, aunque charlatán cuando se trataba de festejarle a Abuelita. Ese día también había ciertas comidas, pero a papá no le podían faltar los encurtidos, que también acompañaba de la probadita del rompope preparado por abuelita con la ayuda de mi hermana. Claro que siendo ocasión especial, se despachaba uno o dos "medios vasos de casco" extra, del "chirrite" que nos abastecía don Bartolo, a lo mejor de una media "de cabeza", que tenía por ahí de entrega especial. Para mí tal vez una copita de rompope y quizá, la mitad o menos del "medio vaso de casco", que me "pasaba por la garganta", 117 dejando esa sensación característica en el paladar y al rato un poco de mareo.

\footnotetext{
116 Ponerse águila: por estar listo y con buena atención a lo que los clientes demandaban. También lo usaba para indicar que no se cometieran errores, por ejemplo en los vueltos a los clientes o en la mercadería que pedían. También se usaba "ipóngase vivo!". Luego se inventó el "póngase las pilas", que popularmente se derivó de un anuncio publicitario de una marca de pilas o baterías de radio o focos.

117 Por derivación de una frase de la canción "El himno al guaro", que popularizó el folclorista Lencho Salazar.
}

ISSN: 1659-0066 


\section{UNA PAREJA MUY ACARAMELADA}

Con cierta regularidad semanal, llegaban a consultar la cartelera de cines. Nos pedían el periódico y durante un rato miraban las opciones ofrecidas para esa noche, para decidir si ir al Reina, al Río, al Guadalupe o, "a más no haber", al Moravia. El caso es que su buen rato se tomaban para decidir. No siempre podíamos seguirles la corriente, aunque no interveníamos para nada en la revisión. Siempre llegaban abrazados, muy abrazados, y así se iban. La ilusión del enamoramiento se respiraba en el ambiente, con solo verlos aproximarse.

Generalmente compraban algo para la casa y algo para ellos. A veces llegaban con la mamá, doña Concepción, quien al rato se iba, o con la hermana menor, quien cursaba los primeros años de la primaria, que si se quedaba su ratillo. El hermano, Alberto Arturo de la Trinidad y los Ángeles de la Concepción de la Santísima "apellido1" y "apellido2", pero solo conocido como Beto, a veces ya estaba en la pulpería, pues era uno de los frecuentes de pasar el rato en el atardecer, o incluso hasta las ocho o nueve de la noche, casi sin hacer nada, simplemente "arregostado" al mostrador o la puerta. La hermana que seguía a la enamorada, un poco menor, aún no le habían llegado esas ilusiones, pero auguraba que sería de lo más hermosa y atractiva, aunque era más callada que la menor y muy dedicada a los estudios, además de totalmente "casera". ${ }^{118}$

Vivieron en una de las casitas de don Gonzalo, pero luego se pasaron como a 50 metros al oeste de la pulpería, a una casa bastante amplia comparada con su anterior residencia. Siempre se mantuvieron como clientes fijos y particularmente amigos, principalmente doña Concepción y Beto, por ser parte de la muchachada de las "tardes noches", luego de su trabajo en un taller mecánico. Las muchachas nunca andaban en las "barrillas" y solo la mayor, era un poco conversadora en la pulpería.

Doña Concepción le hacía a la costura y con la ayuda de su hija enamorada, la pequeña escolar y la hermosa, que ya había iniciado la secundaria, le hacían frente a la vida con bastante holgura, nunca les faltaba nada, salvo el interés de los retoños en la educación: la escuela y uno o dos años de colegio ... y hasta ahí, como era lo normal en el barrio.

${ }^{118}$ Casera: que nunca se le veía en andanzas o juegos por el barrio, sino que pasaba en su casa. 
Luego que los enamorados decidían qué hacer, regresaban a la casita y al rato los veíamos pasar rumbo al cine y luego, al regreso de la "tanda de siete", siempre muy agarrados uno de la otra y a la inversa. En ocasiones se podía repetir la película, con tal de "ir al cine" y pasarla juntos.

\section{LA REVENTADERA DE PÓLVORA}

La calle ocho alrededor de los mercados era (y sigue siendo) un hervidero mercantil, que en ciertas épocas del año incrementa el movimiento de personas. Así ocurría en los meses de noviembre en aquellos años, cuando se aproximaba el día de la Inmaculada Concepción: el 8 de diciembre. Toda esa zona, donde abundaban las "ventas callejeras", en esas fechas se inundaba de ventas de pólvora, que además se extendían hasta un par de cuadras al sur de la Avenida Segunda, detrás de "La Cañada". ${ }^{119}$ Varios negocios cambiaban sus fachadas, para dar gran énfasis al surtido de artefactos pirotécnicos. Por esas cuadras papá había "detectado" en donde nos era más conveniente la "compra al por mayor", para luego revender en la pulpería.

A veces él era quien hacía esas compras. En otras me encargaba ir a ciertos negocios en las tardes, donde podía comprar cantidades de bombetas (de forma triangular), bombas (un poco más grandes que las "bombetas", pero de forma cilíndrica), luces de bengala, silvadores, perseguidores, volcanes y triquitraques. ${ }^{120}$ Estos últimos eran un "chirrión"121 de bombetas circulares amarradas, que revientan en serie y las había de cinco, diez, veinticinco, cincuenta, cien o más bombetas. Los "volcanes" eran de varios tamaños y estilos. Había otras modalidades que en general se decía: "comprar pólvora".

\footnotetext{
119 Era un negocio esquinero en la Avenida Segunda, una de las principales de la capital, cuya ubicación aún hoy sirve de referencia para dar direcciones y debe su fama a la venta de ciertos helados, golosinas, chocolate y café de buen sabor.

120 Entonces no existían las prohibiciones para que los menores de edad manipularan esos artefactos, hoy considerados sumamente peligrosos. Como se ha venido haciendo con otras tradiciones que han sido prohibidas y cambiadas por otras importadas de "países más civilizados". Falta poco para sean prohibidas las "montas de toros" y los "toros a la tica", aunque ciertas empresas les están encontrando el nicho para capitalizar, lo que podría salvarles de la condenatoria a la clandestinidad, como ocurre con los juegos de gallos.

${ }^{121}$ Que se amarran con la mecha, formando una tira o serie de los mismos artefactos, para que exploten de inmediato uno después del otro.
}

ISSN: 1659-0066 
Los más populares eran las bombetas y las bombas, aunque también se vendían bastante los silvadores y perseguidores. Las güilada consumía las bombetas, que se vendían a diez céntimos y las "bombas" a veinte céntimos (supongo que tenían el doble o un poco más de pólvora). Tenían una mechita que se encendía y había que tirarlas de inmediato, no fuera que reventara en la mano. Había quienes las tiraban cuando alguna amistad iba pasando, haciéndolas sonar a la espalda de la víctima. Para gracia el susto, o el disgusto, y la consecuente "vacilada". ${ }^{122}$

En las noches, cuando se juntaban las barrillas, era usual que alguien de pronto dejara ir un perseguidor en el centro del grupo y a "quitarse el tiro", 123 porque el aparatillo se quemaba soltando chispas y haciendo movimientos serpenteantes de manera desordenada, por lo que podía llegar entre las piernas de cualquiera, así que era apropiado para tirarla cuando había muchachas entre las barrillas, pues la juerga que se armaba con los reclamos, bromas y chistes del vecindario. También de pronto alguien quemaba un silvador, que seguía una trayectoria más o menos recta hasta quemarse, cayendo en los techos o patios de las casas, mientras se observaba la estela de chispas escuchándose el sonido como un silvido largo.

Otras formas eran colocar un tarro de jugos del campo vacío encima de una bombeta o bomba, para hacerlo levantar con la explosión y luego ver si se había hundido la lata. También colocarlas en las salidas de los desagües, que en esos años eran tubos como de cinco pulgadas, de una cerámica rojo oscuro, para escuchar el sonido apagado al reventar.

Abuelita sufría un poco con las bombetas, porque había quienes las compraban y tiraban en la misma pulpería, en la acera o colocándolas en las varillas del enrejado de las ventanas. Como ella usaba un audífono, a veces el volumen que le ponía la hacía escucharlas con una mayor potencia de la real. Pero era una "entrada"124 importante en las semanas que duraba. Por cierto que no se extendía hasta la navidad y el año nuevo como ocurre en la actualidad. Solo ocasionalmente alguien mantenía luces de bengala, o algunas bombetas y silvadores, para ir tirando en esos días de manera aislada.

\footnotetext{
122 "Vacilada", Por hacerle bromas o comentarios burlescos.

123 "Quitarse el tiro", por esquivar el rumbo sin dirección fija del artefacto.

124 Que generaba más ingresos a las utilidades de la pulpería.
} 
Casi todos los vecinos compraban algo. Cuando Ramón pasaba, era usual que en esos días se llevaba algunas bombetas, volcanes, triquitraques y luces de bengala. Chavelita y Macho eran compradores de luces de bengala.

La ilusión de las luces de colores y el espectáculo en las salas de las casas, los jardines o patios, la misma acera o calle de enfrente, llamaba mucho la atención de niños y adultos. La novedad de ver el tipo de luces y las estelas que formaban alegraban mucho la vista y la imaginación de los niños. Los volcanes hacían "erupción" de colores, las llamadas "candelas" se podían sostener con la mano, mientras soltaban las luces y unas cuantas "bolas de fuego" de colores.

La mayor "reventadera" del barrio era la que hacían los Calderón, para celebrar la llegada del día de la Inmaculada Concepción, al ser la medianoche. En el barrio era un "fiestón" para todos. Además de los familiares, que eran bastantes, muchos vecinos se aglutinaban alrededor del frente de la casa de José Luis, el abuelito, donde Jorge, Mario y el mismo anciano y doña Nena tenían varios sacos y bolsas con lo que se iba a reventar, compartiendo la celebración, gustosamente, con quienes participaban. Duraban casi una hora en esa "tiradera", donde había de todo y lo más bonito eran los triquitraques, los volcanes, que eran de varios tamaños y las que se tiraban como un cohete, con un palillo liviano a manera de cola, que reventaban iluminando el cielo de colores.

Por supuesto que esa pólvora de los Calderón no era comprada en pulperías. Entonces no habían las prohibiciones de ahora y no recuerdo que en el barrio alguien se hubiera quemado o tenido un accidente con las bombetas o cualquier otro artículo.

\section{ARBOLITO DE NAVIDAD Y NEGOCIOS INESPERADOS}

En la época de navidad, durante varios años la Santísima Trinidad era acompañada de un pasito, que ocupaba parte de los estantes contiguos, al que luego yo le agregué un diseño propio de árbol de navidad. Lo hacía de una rama que ponía a secar durante algunos días. Luego la envolvía con yeso, que preparaba con cierta contextura, para que se pegara a las formas de las ramas del arbolito y secara bien, para darle la apariencia de la nieve. Rociado con escarcha plateada, reflejaba las luces de colores de las 
bombillitas, de las llamadas series, que construía rejuntando bombillos y roscas. Si me hacían falta iba donde Chalo ${ }^{125}$ y compraba de los bombillitas de la serie y completaba una buena iluminación, con la ventaja que como yo construía las series, al tener más bombillos, aunque daban menos iluminación, se quemaban menos, así que duraban para varios años.

La escarcha y la "nieve" se complementaba con las guirnaldas, a las que llamaba "lluvia" y el "cabello de ángel". Estos son unos "puchitos" de hilitos muy finos y largos con apariencia de pelo de bebé, pero blanco, que al distribuirse refleja las luces, o al dejarlas pasar forma halos de colores, haciéndolo bastante llamativo. Además ahí colocábamos las tarjetas, que en época de navidad era usual distribuir entre los vecinos, amigos y familiares. Como teníamos una clientela fija, papá me encargaba que en los alrededores de "La Cañada" o por "La Casona", 126 fuera a contratar la compra de entre cien y 150 tarjetas, que luego se distribuían entre los clientes y vecinos más cercanos, incluyendo a Pascual y doña Tere y familia. Firmaba con el nombre completo de papá y familia.

Éramos retribuidos con la devolución por la cortesía, de manera que eran bastantes las tarjetas que había que colocar en el arbolito. Luego de una primera experiencia debería hacerlos de la dimensión necesaria para colocar a la vista todas las tarjetas, incluso las que nos llegaban de familiares.

Tales arbolitos en algún momento me dejaron un ingreso inesperado, porque a veces alguien pensaba que estaba puesto ahí para la venta y preguntaban a papá, que cuanto valía el arbolito. Como no había pensado en un precio, el cliente potencial debía pasar otro día para ver si lo vendíamos o no. Así que con el consejo de papá, calculé y un par de veces le puse precio y los vendí, aunque realizando cambios en las series de luces, para que no fuera tan "emparchado". ${ }^{127}$ Por supuesto que luego tenía que preparar otro, pues había que tener el arbolito bien bonito para el 24 de diciembre.

\footnotetext{
125 El propietario de la "Ferretería El Mazazo".

126 La Casona: un negocio similar a un mercado, ubicado en el centro de San José, en cuyos los tramos se venden artesanías y "souvenirs" a los turistas que se pasean por la capital, o a los "ticos" que gustan de rememorar o representar ciertas cualidades costarricenses. En esa época había artesanos que se dedicaban a la confección de tarjetas navideñas con varios diseños y tamaños.

127 Por tener varios amarres de las llamadas "series de luces", de diferente origen y forma.
} 


\section{TRABAJANDO EN LA CURTIEMBRE}

Abel, quien alquilaba uno de los cuartos o pequeños apartamentos en los altos de la curtiembre, era muy conversón con papá. De muchos temas hablaban en las tardes de los sábados, domingos y en las noches entre semana. Que si el café, que si el trabajo de peón, que las novillas, que los perros y el tepezcuinte, que si el costo de la vida, que si el diputado que hablaba mucho, que los huelguistas, que el estudio de los carajillas del barrio, que la vagabundería y los tatas que ni les va ni les viene. No siempre parecía tener trabajo, pero papá le tenía confianza y a veces le daba fiado y el señor no dejaba de pagar.

Aunque vivía en ese galerón, no trabajaba para don Fernando, solo de manera ocasional. Se me hacía que como no era joven, y menos robusto de contextura, no se aguantaría las varillas moviendo los cueros de tina en tina. Pero como a veces yo le insistía a papá que quería buscarme un trabajo, para comprar mis cosas y pagarme el colegio; en una de esas que don Abel le comentó que ocupaba un ayudante, para hacer unos huecos o pozos que requería don Fernando, le dijo que porqué no me llevaba a mí, para que me quitara las ganas de andar buscando trabajo.

El caso es que el señor me dijo que si de verdad quería trabajar. Le dije que sí. Y entonces me puso de acuerdo que tal día tenía que estar a las seis de la mañana y lo buscara en la curtiembre. Ahí estuve y nos fuimos dando una ronda por fuera de la edificación. Yo soportando el olor de aquel lugar, pero quería tener un trabajo para obtener un dinero del que pudiera disponer por mi mismo.

En la esquina suroeste, a pocos metros del cañón del río, don Abel conversó con don Fernando, sobre el punto donde debía hacerse el hueco y las medidas. Así que al rato con una macana y dos palas iniciamos. Sería algo así como un cuadrado de dos metros de lado y como dos y medio de fondo.

Al rato ya me pesaba la pala y, como dicen, "sudaba la gota gorda", las manos se me empezaron a enrojecer. Como ya conocía las ampollas que se hacían comencé a cambiar la posición. Don Abel me animaba, "sóquele,"128 que así es como se trabaja". Al rato, "... bueno ... así que quería trabajar, ¡esto es trabajo!" Yo entendía la indirecta: quería hacerme sentir lo duro que

128 "Sóquele": por apurar y no abandonar el ritmo en lo que se está haciendo. 
era el trabajo y así desanimarme para continuar con papá en la pulpería, pues ahí no era tan duro.

Pero de todas maneras, me recordaba los días con el Tío Pablo Antonio y el amor al trabajo que con él había aprendido, el ánimo al iniciar y concluir bien una tarea, aunque no siempre le comprendía muy bien sus enseñanzas. En la construcción de la casa de aquellos tíos, tomaba la pala para ayudar, nivelar o aplanar la tierra, pasar con el carretillo cargado de tierra, piedras o mezcla de cemento. Así que aunque me cansaba y se me hacían ampollas en la mano y, a veces para mis adentros, rogaba por unos guantes para tomar la pala, solo enrollaba un trapo, para tomarla mejor y expulsar la tierra, que mezclada con trozos antiguos de carnazas, íbamos amontonando por fuera del hueco, ya con más de un metro de hondo.

Fueron tres días y medio haciendo el hueco, como un pozo. Los restos más podridos de carnazas que se veían en las paredes, indicaban que ahí mismo, años antes se había hecho otros huecos, para enterrar las carnazas obtenidas de la limpieza de las pieles. Un poco sentía que se me había pegado el olor de la curtiembre.

Al final don Abel me dio veinte colones por mi trabajo, aunque yo esperaba más. No sabía bien cuanto le había pagado don Fernando, pero yo era solo el ayudante y el contrato era con don Abel. Alguno de los operarios de la curtiembre, luego me preguntó que cuánto me había dado don Abel, a quién por cierto le bromeaban mucho, pues los obreros de planta le tenían varios apodos por su contextura y dejo al hablar. "¡Viejo más carebarro, si usted trabajó igual que él, porque solo le dio eso!" "¡Abel, no sea sinvergüenza con el carajillo, debería darle la mitad por haber hecho el hueco!" "iLo justo es más de la mitad, porque trabajó más que usted!"; "No jodan, yo hice el contrato y él solo me ayudó" les contestaba. Y se ponía colorado como un tomate.

Yo me quedé tranquilo con mis veinte colones, pero me dije que no volvería a trabajar con don Abel. Me quedé en la creencia que don Fernando le había pagado ochenta, así que al menos veinticinco o treinta hubiera sido lo justo. Un par de días después papé me preguntó cuánto me había ganado: "¿y así quiere usted irse a trabajarle a otro?" Yo simplemente no contesté nada. En la tarde de ese día, mientras me entretenía un rato con las bolinchas en la calle, lo observé conversando con don Abel. Pero ahí quedó el asunto. Le tomé un 
poco de desconfianza a don Abel, quien de vez en cuando me decía, "iqué ...! ¿quiere trabajar?" No le decía nada, pero tenía mi propia respuesta.

\section{UNAS DÉCADAS DESPUÉS}

Antes de terminar la revisión de estos relatos visité la pulpería. Mientras caminaba por las mismas aceras desde el parque, en la calle hacia el barrio observaba el cambio urbanístico. Unas casas habían dado lugar a negocios de los más variados, unos pocos espacios los han ocupado instituciones de gran importancia nacional. Muchas casas mantenían su estructura original, aunque algunas mostraban con elocuencia el paso de los años. Negocios a los que acudí en algún momento ya no existen, incluso de un par de ellos, por los huecos de las paredes corroídas se observa el abandono y reflejo de los años sin uso.

La casa que albergó la pulpería ahí estaba. Modificada. Los pisos de mosaico eran los mismos, pero los de madera, se habían transformado en ocre sobre el concreto. Ya no se puede decir que sea una casa, pues el negocio ocupa todo el espacio, sin las paredes que separaron las habitaciones. No hay cocina, ni cuartos, ni sala. Solo estantes de mercadería. Aún así parece un local pequeño, en comparación con otros abastecedores de los actuales. La propietaria actual, persona de origen oriental, muy amablemente atendió mis comentarios y preguntas.

Después de ser pulpería, había pasado a ser verdulería, luego por un tiempo, panadería. Pero de unos años para acá de nuevo pulpería, pero en la modalidad y al estilo de abastecedor de autoservicio. Adaptada a las condiciones actuales, unas cámaras de vigilancia y unos barrotes custodian los estantes y la puerta de ingreso de los clientes, que solo se abre si la propietaria le aplica una carga eléctrica. Las ventanas con doble reja. El dinero resguardado y la persona atenta a las actividades y movimientos de los clientes durante su estancia. El negocio ya no se abre tan de mañana, ni permanece abierto hasta tarde en la noche.

Quizá por esto, Mei observaba como me desplazaba por las estanterías, observando los pisos y los puntos donde estuvieron las paredes, así como el cielo raso, donde alguna vez se ocultaron ciertos "secretos". Según me relató mi contertulia, ya no está lleno de arena volcánica, además que una parte de 
la tablilla original ha sido sustituida por cuadros de "plywood", que aparentan sus años, mientras la que sobrevive soporta décadas encima, apenas un poco doblada. Ya no existe la entradita del cielo raso. El patio y la estructura, o caparazón original de la casa son los mismos, aunque ahora el negocio abarca la casa contigua, que también fue de la señora a quien alquilábamos, donde hay bodegas, oficina y cochera.

Al inicio tomé un "frescoleche", para despreocupar a la "pulpera" y luego me presenté. "A veces roban, hay que cerrar el portón", me dijo Mei. "Yo viví en esta casa ... Hace ya bastantes años ...", y la mujer, sin perder su encanto de buena anfitriona y negociante, se mostró un poco sorprendida aunque curiosa, dándome espacio para conversarle. Así le conté como se distribuía la pulpería y la casa y como eran los pisos. El mosaico al que debía "darle lustre", deja ver algunos "camanances"129 y cicatrices.

Me llamó la atención un congelador, muy parecido al que papá compró. Me contó Mei que ya estaba cuando llegó de China y adquirió el negocio hace seis años. La anterior propietaria, una compatriota suya, también le dijo lo mismo cuando compró. Así que no tengo porqué dudar de la marca de fábrica, ni de la capacidad de aquel "chunche", de resistir casi cuatro décadas de ardua labor de enfriamiento, aunque con algunas arrugas encima y a los lados.

Relaté a Mei los precios de entonces, que eran en céntimos, así como los montos aproximados de las ventas totales diarias, que ahora son inconcebibles, pues es mayor el precio de un helado o de un chocolate. La comparación parece irrazonable. Ya no se vende el pan francés, ni el café en onzas, tampoco las kolas y las zarzas, ni muchos otros artículos. Las marcas extranjeras vienen en plásticos. Casi todo viene empacado para la venta al menudeo, aunque Mei vende cigarrillos sueltos, o sea de uno en uno y no solo en paquetes. Los agentes continúan pasando y mientras estuve conversando, tres distribuidores de refrescos gaseosos, acomodaban algunos en las cámaras de refrigeración y dejaron otros en cajas, que también son de plástico y no de madera.

Los clientes no dejaban de llegar, entonces escudriñaba en sus rasgos para tratar de identificar a alguien, pero no tuve éxito. Mei no dejaba de ser amable. Le pregunté por algunos de los vecinos, de quienes no sabía su

129 Camanance: se le dice al pequeño hundimiento en la barbilla o las mejillas de algunas personas. 
destino. También por otros que continúan residiendo en el barrio. Mei me dio razón de varios. Son clientes de la pulpería. Marvin con sus bicicletas, aunque ya es abuelo...

El rato pasaba, así que seguí hacia el sur, con la esperanza de encontrar algunos vecinos y amigos. Dos de los hijos de Arturo tienen un taller de carrocería y pintura en lo que fue su casa. De las hermanas y hermanos, algunas viven en la casa, ahora ampliada y mejorada, otras en las cercanías.

De quienes fueron madres y padres, algunos partieron y están en nuestra espera, mientras otros se mantienen en su senectud. Ya hace tiempo que las melodías de Claudio dejaron de escucharse. El asfalto cubrió lo que fue espacio de juegos y serenatas para las madres.

La casa donde vivió "Jorge el gato" hace tiempo bastantes años dejó de existir. El espacio pasó a ser parte de la calle asfaltada en que se transformó la calle de tierra y el camino que llevaba a las últimas casas de la acera de la pulpería. La algarabía infantil ha sido sustituida por los ruidos de motores, en busca de acortar distancia y tiempo para llegar a las faenas y hogares. 